\title{
HISTORICAL CLIMATOLOGY IN EUROPE - THE STATE OF THE ART
}

\author{
RUDOLF BRÁZDIL ${ }^{1}$, CHRISTIAN PFISTER $^{2}$, HEINZ WANNER ${ }^{3}$, \\ HANS VON STORCH ${ }^{4}$ and JÜRG LUTERBACHER ${ }^{3}$ \\ ${ }^{1}$ Institute of Geography, Masaryk University, Kotlářská 2, CZ-611 37 Brno, The Czech Republic \\ E-mail: brazdil@sci.muni.cz. \\ ${ }^{2}$ Institute of History/NCCR Climate, University of Bern, Unitobler, CH-3000 Bern 9, Switzerland \\ ${ }^{3}$ NCCR Climate, University of Bern, Hallerstrasse 12, CH-3012 Bern, Switzerland \\ ${ }^{4}$ GKSS-Research-Center, Max Planck Strasse 1, D-21502 Geesthacht, Germany
}

\begin{abstract}
This paper discusses the state of European research in historical climatology. This field of science and an overview of its development are described in detail. Special attention is given to the documentary evidence used for data sources, including its drawbacks and advantages. Further, methods and significant results of historical-climatological research, mainly achieved since 1990, are presented. The main focus concentrates on data, methods, definitions of the "Medieval Warm Period" and the "Little Ice Age", synoptic interpretation of past climates, climatic anomalies and natural disasters, and the vulnerability of economies and societies to climate as well as images and social representations of past weather and climate. The potential of historical climatology for climate modelling research is discussed briefly. Research perspectives in historical climatology are formulated with reference to data, methods, interdisciplinarity and impacts.
\end{abstract}

\section{Introduction}

Recent decades have witnessed a growing interest in past climate variability and climate change. This is related to the study of global warming resulting from the anthropogenic enhancement of the greenhouse effect (Houghton et al., 1996, 2001). Corresponding investigations were based mainly on global temperature series since the 1850s (Jones et al., 1986) or the 1880s (Hansen and Lebedeff, 1987; Vinnikov et al., 1990). These global series were further systematically updated and studied in many papers (e.g., Jones et al., 1999, 2001; Hansen et al., 1999, 2001). Historical climate analyses have improved the estimates of anthropogenic effects on climate by providing a more accurate understanding of the natural background climate variability. On a local or regional scale, many instrumental series from individual stations or regions exist, some of them reaching back as far as the 17th century (such as temperature series of Central England since 1659 - see Manley, 1974, or precipitation series for Kew, England since 1697 - Wales-Smith, 1971; Paris precipitation from the 1680s onwards - see Slonosky, 2002; temperature and pressure series from Paris and London - see Legrand and LeGoff, 1992; Slonosky et al., 2001) or the early 18th 
century (homogenised daily temperature and pressure European series - see for instance Jones, 2001; Bergström and Moberg, 2002; Camuffo, 2002a,b,c; Cocheo and Camuffo, 2002; Jones and Lister, 2002; Maugeri et al., 2002a,b; Moberg et al., $2000,2002)$. Prior to these periods and prior to the establishment of national meteorological networks, information on past climates must necessarily be drawn from non-instrumental man-made sources and from proxy evidence obtained from natural archives. A historical source on climate is a document, i.e. a unit of information such as a manuscript, a piece of printed matter (book, newspaper etc.), a picture or an artefact (e.g. a flood mark or an inscription on a house) which refers to weather patterns or impacts of climate. The blanket term of documentary evidence includes all kinds of man-made sources. Documentary evidence may include several types of data. For example, chronicles contain descriptive data (i.e. descriptions of weather spells) that are often combined with documentary proxydata, i.e. observed features in the cryosphere (e.g. snowfalls, snow cover), the hydrosphere (e.g. floods and low water tables) and the biosphere (e.g. stages of vegetation).

Documentary evidence is the basis of many papers on historical climatology (Brázdil, 2000, 2002; Pfister, 2001; Pfister et al., 2001). These papers have produced high-resolution climate reconstructions including time series of climatic anomalies and natural disasters during the period when the effect of human society on nature took place mainly at local or regional scales. Observed climate variability was primarily the result of natural forcings such as solar or volcanic forcing or an interaction of ocean-atmosphere forcing without important anthropogenic effects (greenhouse gases, aerosols, etc.). Historical climatology contributes significantly to the understanding of climate processes prior to systematic human influence on the global atmosphere beginning with the industrial revolution.

This paper provides an overview of the state of the art of historical climatology in Europe. It points to novel fields and research priorities. The development of historical climatology is outlined in Section 2. Section 3 discusses the various sources of data as well as their temporal and geographic extent in Europe. It also gives a detailed overview of the strong points and the drawbacks of documentary data. An overview of the most important research topics is provided in Section 4. In Section 5 significant research results achieved since 1990, during the period of the most progressive development of historical climatology, are presented. Special attention is given to data and methods, the climate paradigm of the last millennium, synoptic views on the past climate and extremes, climatic anomalies and natural disasters, the vulnerability of economies and societies, images and social representations of past climatic anomalies and natural disasters as well as to the potential of historical climatology for climate modelling. Section 6 formulates future research priorities in historical climatology. 


\section{The Development of Historical Climatology}

The development of the historical climatology may be introduced by describing the few definitions that exist in the literature. Balandin (1975) was among the first to use the term in his compilation of natural disasters from Russian chronicles. According to Ingram et al. (1978) historical climatology is "concerned with the study and climate interpretation of descriptive documentary evidence". This definition focuses on the word "historical" and is connected to the period for which written records are available. However, in recent years the term "historical data" has been used in a more fundamental way, merely reflecting the fact that the evidence refers to some period in the past. "Historical data", surprisingly, has even been subsumed under recent series of instrumental measurements (e.g. Vose et al., 1992). Thus, the term "historical data" is becoming ambiguous and misleading. It therefore seems advisable to avoid it altogether and to replace it with "documentary data". This term is on the same level as the many kinds of data known from natural archives (Pfister et al., 1999b).

Fairbridge (1987) expanded the term to the entire Holocene, characterising historical climatology "as the study of the climate through the time-range of civilised Homo sapiens during the period in which human have developed the arts of writing and the construction of permanent dwellings and other structures relating to their maintenance and culture. This time-range varies from region to region. With respect to the world's continually inhabited town Jericho in the Jordan valley, which was established 10,000 years ago, the Holocene epoch became, however, the logical and ultimate time frame of historical climatology." This definition includes the entire Holocene that seems to interfere with the definition of palaeoclimatology (Bradley, 1999).

Hagedorn and Glaser (1990) speak about "historical palaeoclimatology" instead of historical climatology, "which comprises that period for which the direct and/or indirect written climatic information is available". It is close to the concept of Bradley (1999) who presents documentary data ("historical documentary records") among proxy data for palaeoclimatic reconstructions. However, in Chapter 11 of his book he uses also the term historical climatology. Glaser (1996) uses the term historical climatology, but he leaves open its position with respect to palaeoclimatology.

Thus, the field began as a mostly technical approach of describing climate and its variation during historical times and its impact on societies; recently the field is changing towards a truly interdisciplinary field, where natural and social scientists interact (von Storch and Stehr, 1997). In this spirit, following Pfister et al. (2001), historical climatology is defined as a research field situated at the interface of climatology and (environmental) history, dealing mainly with documentary evidence and using the methodology of both climatology and history. It is directed towards the following three objectives: 
(i) It aims at reconstructing temporal and spatial patterns of weather and climate as well as climate-related natural disasters for the period prior to the creation of national meteorological networks (mainly for the last millennium).

(ii) It investigates the vulnerability of past societies and economies to climate variations, climate extremes and natural disasters.

(iii) It explores past discourses and the social representations of the climate.

The term "historical climatology" is also used in a completely different way. For example, in the United States, this term designates serial temperature and precipitation data from the period of network observations (Quinlan et al., 1987). The term "historical climatology" has also been used simply as a synonym for time series analysis of past instrumental observations (Kaas et al., 1996).

The beginnings of a scientific historical climatology, as we define it, are traced back to the late 19th and early 20th centuries. The Swiss physicist Louis Dufour (1870) was the first to discover the value of dates on the opening of vine harvests for the reconstruction of temperatures in the pre-instrumental period. He was followed by the French climatologist Alfred Angot (1885) who provided a catalogue of documentary evidence in France (Angot, 1895). In Switzerland, Eduard Brückner (Brückner, 1890; Stehr and von Storch, 2000a) analysed both instrumental and historical data over many parts of the world and documented transient climate variations, with a preferred time scale of 35 years, in great detail since 1790. In Germany, the climatologist Gustav Hellmann (e.g. 1921, 1926) was another pioneer of compiling documentary evidence in a scientific way. Another early synthesis was prepared in England by Charles Ernest Pelham Brooks (1926). Interestingly, he did not make any distinguishment between contemporary and non-contemporary sources. The same applies to the compilation made by Dutch journalist Cornelis Easton (1928) on winter temperatures. Over the following decades a number of climatologists provided isolated papers on partial reconstructions of past climate in Europe (see e.g. Lenke, 1964, 1968; Manley, 1974; Flohn, 1979, 1985, 1993).

A milestone was the influential monograph of the French historian Emmanuel Le Roy Ladurie (1967) on the climate of the last millennium and its impact on society and history. Following the general paradigm after the demise of the climatic determinism, that social phenomena are supposed to be explained by social processes, Le Roy Ladurie was very reluctant to admit any societal relevance of climatic variations. The British climatologist Hubert Horace Lamb (1913-1997) became his most prominent opponent. He described and analysed the climate fluctuations of the last millennium in his voluminous work (see e.g. Lamb, 1965, 1977, 1982, 1984, 1987, 1991). Lamb (1977) adopted the simple system of indices devised by Brooks (1926) for winter temperatures and summer precipitation and Easton (1928) for winter temperatures, and he was the first to devise synoptic charts of pre-instrumental surface pressure distributions based on documentary data. Together with the German climatologist Hermann Flohn (e.g., Flohn, 1981), 
he was among the scientists who pointed out that societies would do well learning some lessons provided by past climate. In 1979 Lamb helped to organise the first International Conference on Climate and History which brought together a considerable number of climatologists and historians (Wigley et al., 1981).

From the late 1970s the method of temperature and precipitation indices was refined by the Swiss historian Christian Pfister in order to assess monthly and seasonal temperature and precipitation for Switzerland from documentary data. Based upon these reconstructions he then investigated the vulnerability of the major agro-ecological regions to climatic fluctuations (Pfister, 1984, 1988b).

In 1987, the Belgian Pierre Alexandre (1987) published a capacious book on the medieval climate in Western Europe (see also Yan et al., 1997). He tried to systematically apply the rules of historical sources criticism as was suggested earlier, e.g. by Bell and Ogilvie (1978), Wigley (1978) and Ingram et al. (1981). Although his book was a milestone for the critical analysis of medieval records, his method of applying the system of intensity indices was not appropriate (Ornato, 1988). Another problem of Alexandre's book is the lack of detailed information about described events from the original sources. It means that researchers utilising his reports must go back to original material. For example, Brázdil and Kotyza (1995) criticised his reports from the Czech Lands with regards to their completeness, interpretation and derived indices. The handling of medieval records and the reconstruction of medieval climate was further developed by Pfister et al. $(1996,1998)$ and Schwarz-Zanetti (1998). Neumann (1985) investigated the classical Greek and Roman literature for references to climatic change. Panessa (1991) compiled a substantial number of sources on the climate and environmental history of Ancient Greece. For the Byzantine world a handsome synthesis covering the entire medieval period from 300 to $1500 \mathrm{AD}$ was recently provided by Telelis $(2000,2004$; see also Stathakopoulos, 2003).

Over the 1990s, climate research was stimulated by discussion related to the enhanced greenhouse effect. Therefore the interest for studies on climatic change prior to the human-induced time period also grew rapidly. A loose network of scholars engaged in historical climatology emerged in this context around research programmes of the European Science Foundation (see e.g. Frenzel et al., 1992, 1994) and the European Union. For example, 50 geographers, environmental historians, palaeoecologists, physicists and meteorologists originating from 15 European countries engaged in the study of the Late Maunder Minimum (LMM), as the period from 1675 to 1715 was called (e.g. Frenzel et al., 1994; Wanner et al., 1994, 1995) and subsequently this period became a focus for further climatological analyses (e.g. Pedersen, 1996; Barriendos, 1997; Alcoforado et al., 2000; Luterbacher, 2001; Luterbacher et al., 2001; Xoplaki et al., 2001; Shindell et al., 2001, 2003; von Storch, 2004; Zinke et al., 2004).

Based on a critical evaluation of the sources and methodology used by Pfister (1984) in Switzerland, the creation of a series of temperature and precipitation indices was extended to the Czech Republic (Brázdil, 1996), Germany (Glaser, 1997), 
Hungary (Rácz, 1999) and the Low countries (i.e. the present-day Netherlands and Belgian Flanders - van Engelen et al., 2000, 2001). Corresponding index series for these regions and partly for Italy and Poland were presented for the 16th century by Glaser et al. (1999b). Ogilvie and Farmer (1997) published temperature and precipitation indices for England for the period AD 1200-1439. Alcoforado et al. (2000) and Xoplaki et al. (2001) developed monthly temperature and precipitation indices for the Late Maunder Minimum period for Portugal and Greece, respectively. Instead of index series, time series quantified in terms of temperature $\left({ }^{\circ} \mathrm{C}\right)$ and precipitation $(\mathrm{mm}$ or $\%$ ) units and expressed, for instance, in the form of anomalies from a more recent reference period (e.g. 1901-1960) forms a set of climatological analyses that are easily comparable. Pfister and Brázdil (1999) calculated such average series of temperature and precipitation anomalies in Central Europe for the 16th century by weighted averaging of data from Germany, Switzerland and the Czech Republic. Similar quantitatively interpreted series, based mainly on documentary evidence in Europe, are available for Switzerland (Pfister, 1984, 1999), Germany (Glaser et al., 1999a; Glaser, 2001), the Low countries (van den Dool et al., 1978; Buisman and van Engelen, 1995, 1996, 1998, 2000; van Engelen et al., 2000, 2001; Shabalova and van Engelen, 2003), Hungary (Rácz, 1999), Andalusia (southern Spain; Rodrigo et al., 1999, 2001) and on the decadal scale for the Czech Republic (Brázdil, 1996).

A further step in climate reconstruction was achieved by Guiot (1992) who used a combination of documentary proxy evidence, European and Moroccan tree-ring data and ${ }^{18} \mathrm{O}$ data from Greenland to provide annual temperature estimates from AD $1068-1979$ for the area $35^{\circ} \mathrm{N}-55^{\circ} \mathrm{N}$ and $10^{\circ} \mathrm{W}-20^{\circ} \mathrm{E}$. He found a significant connection between Northwest Europe and the Central Mediterranean region (Italy) during the 'Little Ice Age', while the Western Mediterranean region (Spain, Morocco) had not experienced any significant cooling. Mann et al. (2000) later on used a multi-proxy predictor network, including a combination of documentary data and natural proxy data, in order to derive seasonal and annual temperature patterns for Europe back to the mid-18th century. Further, Luterbacher et al. (1999, 2000, 2001, 2002a,b, 2004) were able, statistically, to derive spatial charts of monthly (back to 1659) and seasonal (back to 1500) reconstructions of temperature, sea level pressure, 500-hPa geopotential height fields, North Atlantic Oscillation and other circulation indices as well as precipitation from documentary and early instrumental series for the whole of Europe (see Section 5.2). Luterbacher and Xoplaki (2003) recently derived gridded and spatially averaged temperature and precipitation series over the last 500 years for the Mediterranean land area.

Another recent development is the attempt to reconstruct climate and climate variations outside the regions for which documentary data are available. Two approaches are in use, namely an empirical statistical one, and the approach with the use of physical climate models.

The empirical statistical line of research is using the statistical upscaling concept, i.e., regional reconstructions of temperature and precipitation in Europe are used 
to estimate the state of the North Atlantic Oscillation (NAO) and other parameters of atmospheric circulation (e.g. Luterbacher et al., 1999, 2002a,b; Schmutz et al., 2000; Wanner et al., 2001). But the NAO influence on temperature and precipitation at specific locations can vary with time (see e.g. Jacobeit et al., 2001; Pozo-Vazquez et al., 2001; Slonosky and Yiou, 2002; Jones et al., 2003a). The empirical approach is limited by the necessary condition that the empirically determined upscaling relationship remains stationary during the course of time, which does not seem always to be the case (Schmutz et al., 2000; Luterbacher et al., 2002a,b; Zorita and González-Rouco, 2002).

The dynamical line of research relies on physical climate models (energy balance, radiative-convective or general circulation models - GCMs). These models have been integrated subject for reconstructed forcing factors such as volcanic aerosols in the stratosphere, greenhouse gas concentrations and solar luminosity variations for several hundred years (e.g., Cubasch et al., 1997; Crowley, 2000; Fischer-Bruns et al., 2002; Bauer et al., 2003; Zorita et al., in press). This has become possible after significant progress has been made in reconstructing the history or relevant time-variable forcing factors, in particular the atmospheric load of volcanic aerosols and the output of the Sun (Crowley, 2000). The response of physical climate models of different complexity to this forcing history can be used to estimate past climate variations (for example, see Section 5.7) and to determine the sensitivity of the climate system to external forcing. The skill of the dynamic approach is limited not only because of computation restrictions, the need to parameterise various important physical processes, and the incomplete knowledge about the forcing factors. It is also limited because the state of the climate system is only partially determined by external factors (Hasselmann, 1976; Cubasch et al., 1994; von Storch and Hasselmann, 1996). The recently developed concept of "Data Assimilation Through Upscaling and Nudging" - DATUN (see von Storch et al., 2000; Widmann et al., in press) may overcome this problem, but the method is still in its infancy.

Over the period of the greatest advances in historical climatology, historians turned away from the study of climate as a potential impact factor, even within fields of potential vulnerability such as demography or agrarian history (Pfister, 2001). The discourse about the potential impact of climate on society and history continues to suffer from the legacy of climatic determinism (for an account, see e.g., von Storch and Stehr, 1997; Stehr and von Storch, 2000b). According to this school of thought (e.g., Brückner, 1890; Semple, 1911; Huntington, 1925; Markham, 1947), the skills and properties of people, the changing political power configurations, suicide rates, stock market variations and many other psychological, intellectual and social attributes and processes are the outcome of climatic conditions and variability. Together with other types of environmental determinism, this theory was solidly discredited in the latter half of the 20th century; at present, however, these views are still present in everyday life. In the social and cultural sciences, Emile Durkheim's principle (Durkheim, 1982) that social phenomena have to be explained as the result of other social processes dominates the discourse. Hardly 
any reputable contemporary social and cultural scientist advocates the principle that environmental conditions have a direct, unmediated impact on social life. This obviously represents somewhat of a problem since much of the debate about anthropogenic climate change and its impact on modern societies is implicated in this issue. As a result, natural scientists, less aware of and less affected by past debates among cultural and social scientists often summon everyday knowledge in order to refer to the ways and the strength in which climate impacts acquire on society. As a result, a not insignificant part of climate impact research is indebted to the ideology of climatic determinism.

Fortunately, more recently, there is a growing interest in cultural history in the perception and the ways of coping with climatic anomalies and natural disasters. An excellent example is the analysis by Pfister and Brändli (1999) of the societal response to flooding in the mid-19th century in Switzerland, which ultimately led to beneficial legislation against logging in the Alpine mountains although the law was based on the false premise that such logging was responsible for the frequent floods the country experienced at that time. The Swiss case study may serve as a relevant analogue for contemporary public discourse on natural disasters, human influences and social impacts. Another such case is the description by Brönnimann (2002), who showed that the same symbols of climate change (palms and glaciers) were used in the early 20th as in the late 20th century. The most recent concern about anthropogenic climate change is historically not a new phenomenon. It was described by Brückner (1890) and more broadly by von Storch and Stehr (2000, 2002). Further debate on this topic occurred recently (September 2002, Göttingen, Germany) at a conference on the "Cultural consequences of the Little Ice Age" (Behringer et al., in press).

The main achievements of the period since 1990 are listed in Table I. They are discussed in somewhat more detail in subsequent sections of the paper.

\section{The Potential and the Limitations of Documentary Data}

The data base for historical-climatological research can be broadly categorised as being either direct or indirect data. The direct data can be thought of as descriptive documentary data, for example narrative descriptions of weather patterns or early instrumental measurements. Indirect or documentary proxy data reflects the impact of weather on elements in the hydrosphere, the cryosphere or the biosphere (e.g. floods, the freezing of waterways or the beginning/end of grain or wine harvest). According to their origin, indirect data can be either man-made or based on natural proxy evidence (Figure 1).

Documentary data are the only kind of palaeoclimatic data that are based on direct observations of different meteorological parameters (temperature, precipitation, snow-cover, sea ice distribution, cloudiness, wind, lake levels etc.) in terms of narrative descriptions and/or early instrumental measurements. For this reason they 
TABLE I

Main achievements in historical climatology in Europe since 1990

(i) Broader use of traditional documentary evidence including new kinds of sources (see Section 5.1). Building up and improving historical climatological data bases (e.g. HISKLID for Germany, EURO-CLIMHIST for Europe) (http://www.euroclimhist.com/; Dietrich, in press).

(ii) Standardisation of the methodology of intensity indices (see Section 4.1).

(iii) Validating the intensity indices (see Sections 4.2 and 4.3).

(iv) Multiproxy mapping (see Section 5.2).

(v) Statistical derivation of spatial variability of temperature, air pressure and precipitation distribution for the whole of Europe (see Section 5.2).

(vi) Defining the Medieval Warm Period (MWP) and the Little Ice Age (LIA) (see Section 5.3).

(vii) Climatological and statistical analyses of climatic anomalies and natural disasters (see Section 5.4).

(viii) Impacts of climate and natural disasters on and the adaptation strategies of past societies (see Sections 5.5 and 5.6).

(ix) First extended reconstructions of global climate conditions with full climate models, as a response to time variable forcing factors (volcanic aerosol load, solar output, greenhouse gas loads) (see Section 5.7).

\begin{tabular}{|c|c|c|c|c|c|}
\hline $7^{\text {Archives }}$ & \multicolumn{2}{|c|}{ Natural } & \multicolumn{3}{|c|}{ Man-made } \\
\hline $\begin{array}{l}\text { direct observation } \\
\text { of weather and climate } \\
\text { or } \\
\text { instrumental } \\
\text { measurement } \\
\text { of meteorological } \\
\text { parameters }\end{array}$ & & & $\mid \begin{array}{c}D \\
0 \\
\text { c } \\
\mathbf{u} \\
\mathrm{m} \\
\mathrm{e}\end{array}$ & $\begin{array}{l}\text { observed } \\
\text { - anomalies } \\
\text { - natural hazards } \\
\text { - weather situations } \\
\text { - daily weather }\end{array}$ & $\begin{array}{l}\text { measured } \\
\text { - barometric } \\
\text { pressure } \\
\text { - temperature } \\
\text { - precipitation } \\
\text { - water-gauge, } \\
\text { etc }\end{array}$ \\
\hline $\begin{array}{l}\text { indirect references: } \\
\text { (Proxy data) } \\
\text { indication of controlled } \\
\text { or affected processes } \\
\text { through meteorological } \\
\text { parameters }\end{array}$ & $\begin{array}{l}\text { organic } \\
\text { - tree rings } \\
\text { - fossil } \\
\text { pollen } \\
\text { - animal and } \\
\text { plant remains } \\
\text { - fossil wood } \\
\text { (trees), etc. }\end{array}$ & $\begin{array}{l}\text { non-organic } \\
\text { - ice-cores } \\
\text { - varves } \\
\text { - terrestrial } \\
\text { sediments } \\
\text { - temperature } \\
\text { of boreholes }\end{array}$ & $\begin{array}{l}\mathbf{n} \\
\mathbf{t} \\
\mathbf{a} \\
\mathbf{r} \\
\mathbf{y}\end{array}$ & $\begin{array}{l}\text { organic } \\
\text { - plant phenology } \\
\text { - yield of vine } \\
\text { - time of grain and } \\
\text { vine harvest } \\
\text { - sugar content of } \\
\text { wine, etc. }\end{array}$ & $\begin{array}{l}\text { non-organic } \\
\text { - water levels } \\
\text { - snow fall } \\
\text { - freezing of } \\
\text { water bodies } \\
\text { - snow cover, } \\
\text { etc. }\end{array}$ \\
\hline & & $\begin{array}{l}\text { - moraines, } \\
\text { etc. }\end{array}$ & & • pictorial & $\begin{array}{l}\text { rogations } \\
\text { - epigraphical }\end{array}$ \\
\hline & & & & terial: & $\begin{array}{l}\text { - archeological } \\
\text { remains }\end{array}$ \\
\hline
\end{tabular}

Figure 1. A survey of evidence for reconstructing past weather and climate (Pfister, (C) Paul Haupt Verlag 1999).

can be used both for verification of extreme values in natural proxies such as tree rings (see e.g. Vogel et al., 1996; Brázdil et al., 2002a) and for detailed descriptions of past weather such as after major volcanic eruptions (see e.g. Stothers, 1996, 1999, 2000; Demarée et al., 1998; Demarée and Ogilvie, 2001). Most importantly 
they are the only evidence that is directly related to the socio-economic impacts of rare but significant disasters such as intense storms, severe floods, and long-lasting droughts in the period prior to the organisation of instrumental network observations. For this reason, reconstructions based on documentary data play an important role in the enhanced greenhouse debate.

Moreover, apart from vine harvest dates, a great variety of other documentary proxy data were discovered over the past 25 years. Direct or indirect references to physical and biological indicators of the environment are more or less systematically included in narrative sources, as many observers were well aware that their records included a subjective bias. Compared to descriptive documentary data which are limited by the activity of the observer, some kinds of documentary proxy data, inasmuch they are produced by administrative routine (e.g. vine harvest dates), are available over periods of several centuries.

Early instrumental records made before the beginning of systematic meteorological observations, in most cases cover only short periods or have sporadic character. Lack of detailed knowledge of the instruments and of their locations makes linkage to the modern reference period difficult and requires careful homogenisation (e.g., Wishman et al., 1998; Moberg et al., 2000; Brázdil et al., 2002b; Camuffo and Jones, 2002). Beginnings of instrumental observations in Europe have been summarised, for instance, by Frisinger (1977), Kington (1988), and in a greater detail they were described by Camuffo (2002a). The basis for it was the invention of some meteorological instruments by Galileo Galilei (1564-1642), his students and followers in Italy. It was realised that the value of instrumental observations would be importantly enhanced if measurements could be made simultaneously at different places. The first international meteorological network, called Rete Medicea, started between the years 1653-1654 with ten European stations. It was established by the Grand Duke of Tuscany and a founder of the Accademia del Cimento (Academy of Experiments) in Florence (in 1657), Ferdinand II, and his brother Prince Leopold de' Medici. The network ceased to function after the Accademia del Cimento was disbanded in 1667.

Johann Kanold, a doctor in Breslau (i.e. Wrocław, Poland), organised the first network of correspondents in Central Europe and published quarterly instrumental measurements and weather reports from 1717 to 1726 in "Sammlung von Natur- und Medicin, wie auch hierzu gehörigen Kunst- und Literatur-Geschichten" (Kanold, 1718-1727; see also Hellmann, 1914; Brázdil and Valášek, 2002; Munzar, 2002). It was continued from $1727-1730$ by Andreas Elias Büchner, a professor of medicine at Erfurt (Germany), in "Miscellanea Physico-Medico-Mathematica, oder angenehme, curieuse und nützliche Nachrichten von Physical- und Medicinischen-, auch dahin gehörigen Kunst- und Literatur-Geschichten".

Another attempt to organise an international meteorological network was done in 1723 by James Jurin, secretary of the Royal Society of London (Jurin, 1723). This network existed between 1724 and 1735 and observations were published in the Philosophical Transactions. 
In 1780, Karl Theodor, the elector of the Palatinate, set up the most important early international network in the form of the "Societas Meteorologica Palatina." At the time of its largest extension, the network of this society comprised 39 stations ranging from Greenland to Rome and from La Rochelle (France) to Moscow. All the stations used standardised instruments and made their observations according to the regulations issued by the society with annual publishing of their results during 1780-1792 (Kington, 1988).

Some of the very early measurements have been systematically analysed. One of the pioneers of instrumental observations was Louis Morin, a physician in Paris. His observations, including three daily readings of temperature and pressure, were carried out in 1665-1713 (Legrand and LeGoff, 1992; Pfister and Bareiss, 1994). Based on observations of Nicolaus Cruquius, a cartographer and hydraulic engineer, the Delft/Rijnsburg series (the Netherlands) of monthly temperatures for 17061734 was rediscovered and published by van Engelen and Geurts (1985). Another of their compilations shows an example of a basic metadata of early instrumental measurements (Geurts and van Engelen, 1992). Kington (1988) collected a list of many further instrumental records in Europe, made during the 1780s.

Meteorological activities of many physicians were connected with the neoHippocratic hypothesis about the relations between the climate and human health. It had its origin in Hippocratos of Chios (born about 460 - died probably in 377 B.C.), a Greek physician and philosopher, who considered a disease as the failure of balance between the organism and the environment, including the weather and climate. Hippocrates' ideas appeared in modern times in the work of the English physician, Thomas Sydenham, (1624-1689) who believed that atmospheric conditions played an important role in diseases. The action of the climate on man was, according to 18th century physicians, due to the effect of air which man inhales. The effort in quantifying the effect of meteorological conditions then led the physicians to perform meteorological observations (Demarée, 1996).

Descriptive documentary evidence includes both direct data about the weather and about phenomena and events dependent on the weather. This is an exceptionally rich source, including written reports from annals, memoirs and chronicles, daily weather reports, personal and official correspondence, travel diaries, economic records, pictures, leaflet newspapers, early journalism, ship logbooks etc. Epigraphic records of extreme weather (for instance floods) include inscriptions and marks on stones, rocks, bridges or buildings. Such records may contain either sporadic or continuously recorded data. In all cases it needs to be assessed whether a source is contemporary, i.e. whether authors witnessed the events they describe or whether these events at least occurred during their life-time. Observations, which were copied from other documents or compilations, often contain transcription errors in the dates of observations (e.g. Bell and Ogilvie, 1978; Ingram et al., 1981; Schwarz-Zanetti, 1998). If events were copied from other chronicles, misdating occurred frequently. For instance, Bell and Ogilvie (1978) showed a spurious multiplication of a storm flood event in Flanders on 16 November 1377: Weikinn's 
(1958-2002) compilation includes seven different references to this event dated from 1374 to 1377, based on one single original source (Chronicon comitum Flandrensium). Correct dating is a difficult problem. In 1582 Pope Gregory reconciled the old Julian calendar to an exact degree by cutting off 10 days. Dates prior to this year need to be corrected accordingly (Bachmann, 1984; Alexandre, 1987). Gregory's reform was only adopted piecemeal, even in the catholic world. Thus, it must be assessed for every territory, whether the 'old' or the 'new' style was eventually used. For example, England adopted the New Style by an Act of Parliament as late as 1752 (Grotefend, 1982). Furthermore, there is a considerable variation in the beginning of the year. In the Middle Ages no less than seven possibilities were known. Most medieval sources are tacit with respect to the dating which they used (von Brandt, 1996). For events in 'winter', many sources give just one year for identification. In this case it must be derived from the context or from other sources whether the 'old' or the 'new' year is meant (Pfister, 1992). Roman numbers that were in use into the late 17th or early 18th century are particularly error-prone. An example is provided by Camuffo and Enzi (1992): The 18th century chronicler Giuseppe Toaldo through a reading error, changed an X into II, transforming the year MDXI (1511) into MDIII (1503), and wrote that the artillery of Pope Julius II crossed the frozen river Po in this year. This statement was then propagated as an independent event, in addition to the correctly reported event of 1511 . In his critical catalogue of more than 3500 "climatic texts" from AD 1000 to 1425 Alexandre (1987) lists 300 inconsistencies of this kind (for critical evaluation of medieval weather reports see e.g. Malewicz, 1980 for Poland, Brázdil and Kotyza, 1995 for the Czech Lands and Kiss, 1999, 2000 for eastern Central Europe). Suspicion should be thrown on compilations of climatic events, including recent ones, for which it is not assured that sources were critically evaluated.

In interpreting medieval documents the particular conditions in which the documents were created need to be considered. Many manuscripts are anonymous and the year of composition is not given. Analyses of handwriting yield only approximate results. Occasionally authorship may be derived from personal remarks in the text. Even if the name of an author is known, their exact lifetime is often ignored. Thus, it may be difficult to assess whether an author actually witnessed the event described. Before the art of printing was invented in the 15th century, books had to be copied by hand. During the Early and High Middle Ages this was done in the scriptoria of monasteries. For this purpose manuscripts were frequently exchanged between monasteries. As a consequence, chronicles may have survived in a number of copies which are not entirely identical and which are today often deposited in libraries of different countries or private collections. The philological work of critical text edition attempts to assess which is the oldest manuscript - the archetype and to establish its relationship with the more recent copies (van Caenegem, 1979; Faulstich, 1996).

Uncritical use of documentary data is not only found in compilations of weather reports from different sources (such as Strnadt, 1790; Amberg, 1890; Hennig, 1904; 
Weikinn, 1958-2002), but it is also found in more recent publications of authors who are not so familiar with documentary evidence (for example Bernhardt and Mäder, 1987 used as basic data reports of Hennig, 1904). Moreover, Hennig's (1904) reports have also been used as the basic data source for description of past weather patterns in Western Europe (e.g. Barash, 1989). Questionable reconstructions of climate from documentary data should not be blamed on the chroniclers without justification. Rather an improper interpretation of data by the researcher should be assumed.

Archaeological data, including for instance evidence of extinction and desertion of settlements, are often taken as resulting from the long-term effects of climate and/or climatic extremes, but the connection with climate is in many cases ambiguous (Brázdil and Kotyza, 1995). In most cases, a direct effect appears unlikely, but deteriorating climatic conditions may have aggravated problems in the social organisation and functioning. On the other hand, DeMenocal (2001) has presented four case studies drawn from New and Old World civilisations, integrating detailed archaeological and palaeoclimatic records, in which he has shown their societal responses to prolonged droughts, including population dislocations, urban abandonment and state collapse.

Using records from natural archives or series of documentary proxy data (e.g. wine harvest dates) the climatic signal needs to be extracted from a series of proxy data. As a rule, the climatic information obtained relates to a certain type of meterological data, such as air temperature or precipitation, with a time resolution of months or longer. The most frequently used natural proxies are those relating to the historical fluctuations of glacier tongues, changes in the composition of ice cores, tree rings (ring width and density of late wood), pollen-profiles, varved sediments taken from the sea floor or from lake floors, erosion furrow fills, geothermic evidence, speleothem records, corals, etc. (e.g., Holzhauser, 1997; Bradley, 1999; Huang et al., 2000; Proctor et al., 2000, 2002; Baker et al., 2002; Zinke et al., 2004). However, most reconstructions from natural archives cannot be broken down to seasonal or monthly resolution and they do not always yield a distinct separation of the effects of temperature and precipitation (Bradley, 1999). But this high resolution is needed for investigating climatic impacts on societies. Mann et al. (2000) recently published warm and cold-season reconstructions for Europe back to 1760 . The uncertainties, however, are quite large for these estimates.

Series of documentary proxy data are mostly drawn from administrative records. Often such series are long, continuous and quasi-homogeneous so that they can be calibrated against instrumental measurements. Documentary proxy data may reflect the beginning of agricultural activities such as the grain or the vine harvest, agricultural production (e.g. yield of vineyards), the time of freezing and opening up of sea-ports or inland waterways, or that of religious ceremonies (e.g. Pfister, 1979, 1981, 1984; Tarand and Kuiv, 1994; Martín-Vide and Barriendos, 1995; de Kraker, 1999; Brázdil and Kotyza, 2000), or the sailing time needed for routine journeys (e.g., García et al., 2000). 
Phenology which is "the art of observing life cycles, phases or activities of plants and animals in their temporal occurrence throughout the year" (Lieth, 1974), has gained attention within the global change community over the last few years as an important indicator for global change (Menzel, 2002). A trend towards earlier spring phenophases during the last 50 years taken from a wide range of different data has been reported for the northern mid-latitudes. Menzel and Estrella (2001) provide an overview over the data sets known in this community. However, only a few historical data sets reaching back further than 50 years have been analysed (e.g. Sparks and Carey, 1995; Maak and von Storch, 1997; Nordli, 2001) even though plant observations carried out by volunteers and amateurs date back for several centuries (Pfister, 1992).

Documentary proxy data is made up of a broad variety of indicators that are as different among themselves as natural proxy data. Each kind of documentary proxy data needs to be calibrated against (early) instrumental series and is restricted to specific periods of the year in the same way as natural proxy data.

In relation to natural proxy data, descriptive documentary data has its advantages and limitations, which are respectively detailed below (Pfister et al., 1999b):

(i) Good dating control and high temporal resolution.

(ii) Clear distinguishment of meteorological elements in the narrative reports (e.g. temperature, precipitation, snow cover, wind).

(iii) Focus on anomalies and natural disasters.

(iv) Taken together they cover all months and seasons (even autumn).

The following drawbacks are mentioned (Pfister et al., 1999b):

(i) Discontinuous structure of the records (due to the death of observers).

(ii) Bias by the selective perceptions of observers.

(iii) Mathematical analysis is simple but robust, however this may be a drawback for the acceptance of results in the scientific community.

The geographical range of documentary data depends on (Pfister, 2001):

(i) The sedentary presence of literate individuals. This excludes the high altitudes and high latitudes.

(ii) An appropriate institutional and cultural framework (e.g. the existence of conventions, the existence of local elites in towns).

(iii) A tradition of keeping chronicles of extraordinary events based on eyewitness observations.

As far as Western and Central Europe is concerned, the temporal range is restricted to the past millennium. Over that period the density and quality of information increases as follows (Pfister, 2001):

(i) Prior to AD 1300: Reports of socio-economically significant anomalies and (natural) disasters. 
(ii) 1300-1500: More or less continuous reports on characteristics of summers and winters (to some extent also on those of spring and autumn) including reference to "normal" conditions.

(iii) 1500-1800: Almost complete description of monthly weather, to some extent also of daily weather. Growing number and diversity of continuous series of documentary proxy data produced by the early modern local, regional and state bureaucracies.

(iv) 1680-1860: Instrumental measurements made by isolated individuals. First short-lived international network observations (e.g. Breslau-Network and Palatine-Network).

(v) From 1860: Instrumental observations in the framework of national and international meteorological networks.

The list needs to be understood in a cumulative way, i.e. older kinds of climate observations are not replaced but superposed by more recent ones. In sum, the quality of the data improves, their density and their time resolution increases and their spatial coverage extends over time.

Outside the Byzantine empire (see e.g. Telelis, 2000, 2004; Stathakopoulos, 2003) the conditions mentioned above were met first in the reign of Charlemagne (9th century AD) that includes most of the territory of contemporary Germany and France, Belgium and the Netherlands, Switzerland and Northern Italy, as well as in Ireland (Crawford, 1989) and to some extent in England. From about AD 1050 the tradition of keeping chronicles spread to the territories of contemporary Catalonia (Spain), the Czech Republic, Denmark, Hungary, Iceland, Poland and Slovakia, later on also to the Baltic, Russia and the territory of contemporary Finland. Records from southeastern Europe are scanty until the 18th century.

\section{Methods of Analysis}

A possible procedure of data analysis and climate reconstruction is shown in Figure 2. It usually starts with the search of suitable documentary data or natural proxy indicators that are able to define a high amount of climate variability of a certain climate variable like temperature, precipitation, air pressure, etc. All proxies are then transformed into a time series with a clearly defined temporal resolution. In the case of natural proxies this is often a very complex procedure requiring specialised laboratories applying sophisticated physical and chemical analysis techniques. In the case of documentary data, the statistical transformation into ordinal data in the form of a time series of indices is also a great challenge requiring a broad statistical and dynamical understanding.

\subsection{THE DERIVATION OF PROXY SERIES BASED ON DOCUMENTARY EVIDENCE}

In most cases a climate reconstruction involves different kinds of documentary data. If the data-basis is broad enough, one may expect that the strengths and 


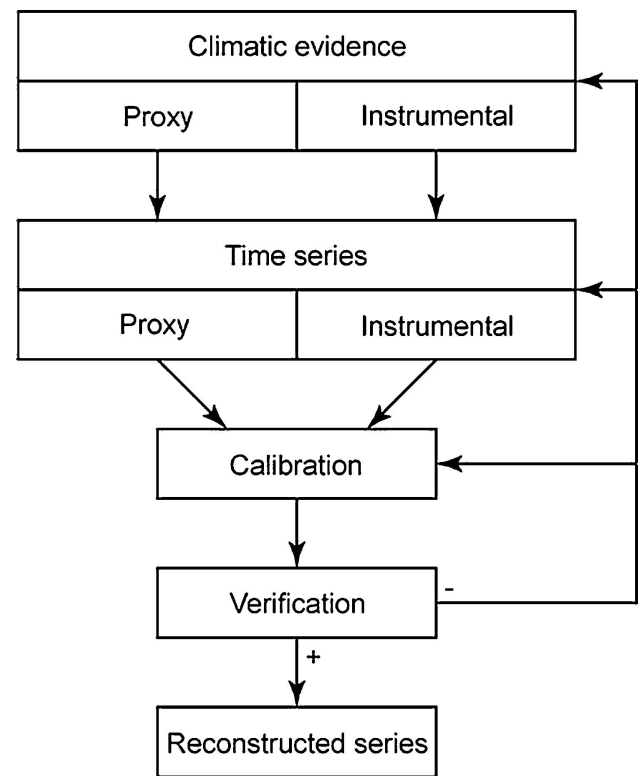

Figure 2. The process of climate reconstruction, including documentary data (Brázdil, (c) SpringerVerlag 2002).

weaknesses of different data types control and complement each other to a certain degree (Pauling et al., 2003). The first step in the procedure includes evaluation of available documentary data with consideration of critical analysis of sources, author and/or institutional framework, calibration of documentary proxy data, etc. The comparison and cross-checking of data from different documentary sources, both direct and indirect, should allow assessment of an unequivocal climatic tendency, within a given temporal and spatial domain. This tendency is expressed in form of an intensity index for temperature and/or precipitation which is attributed to the month or season under investigation (Pfister, 2001). Series of intensity indices obtained from documentary evidence should overlap the period of instrumental measurements. This is only possible for a few cases and very distinct periods (Pauling et al., 2003).

Useful values from documentary evidence are obtained by transforming the basic data into simple and weighted temperature and precipitation indices on an ordinal scale. Simple monthly indices use a three-term classification (temperature: 1 warm, 0 normal, -1 cold; precipitation: 1 wet, 0 normal, -1 dry). Weighted monthly indices are based on a seven-term classification for temperature (3 extremely warm, 2 very warm, 1 warm, 0 normal, -1 cold, -2 very cold, -3 extremely cold) and for precipitation correspondingly. Seasonal or annual indices are obtained by summation of monthly values. Thus, in simple indices the three-month seasonal values (e.g. DJF, MAM, JJA, SON) can fluctuate from -3 to 3 , weighted ones from -9 to 9 . In order to make weighted indices compatible with the simple ones, they can be divided by 3 and issued with one decimal place. Compilation depends on 


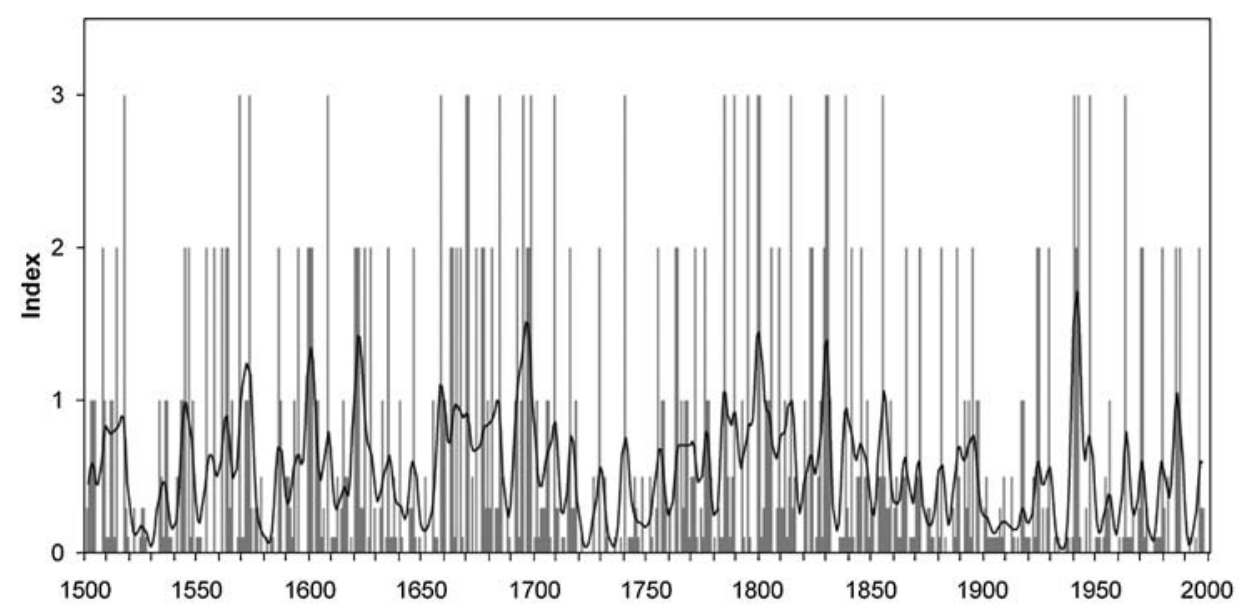

Figure 3. Fluctuations of ice winter index in the western Baltic in 1501-1995 (data in Koslowski and Glaser, 1999). Smoothed by a 10-year Gaussian filter.

the density and quality of the basic information, and is to some extent affected by the subjectivity of the researcher.

Scaling into ordinal numbers is an obvious step when dealing with documentary data. To mention some examples, Wang et al. (1991) scaled climate indicators for definition of warm/cold climate index in China from 0 to $3(0-$ no records, 1 existing, 2 - severe, 3 - extremely severe), while van Engelen et al. (2001) used an ordinal scale from 1 to 9 for reconstruction of winter (from 1 - extremely mild to 9 - extremely severe) and summer (from 1 - extremely cool to 9 - extremely warm) temperatures in the Low countries. The index approach is also applied to proxy documentary data. Koslowski and Glaser (1999) developed an ice winter index (Figure 3) from accumulated areal ice volume along the German Baltic coast with gradation of winter severity types: 0 - weak, 1 - strong, 2 - very strong, 3 -extreme.

Pfister (1999) suggested to begin reconstruction of intensity indices from the instrumental period, where most variables are available and then to work subsequently backwards, where less and less details are known. This approach called "Wetternachhersage" (i.e. backward-reconstruction) should not be done chronologically, but according to types of anomalies.

Prior to further elaboration of this method (i.e. calibration, verification and reconstruction), three important questions have to be asked:

(i) Which are the best predictors?

(ii) Which are the best sites for an accurate prediction?

(iii) Which are the best methods to sort out best predictors and sites and to get valuable spatio-temporal reconstructions?

In recent years sophisticated methods were developed to give answers to these questions (e.g., Bradley, 1996; Kaplan et al., 1997; Evans et al., 1998; Jones et al., 
1998; Mann et al., 1998, 2000; Luterbacher et al., 2002a, 2002b, 2004; Mann, 2002; Bradley et al., 2003). In a recent paper by Pauling et al. (2003) it was shown that an optimised combination of high quality natural and documentary proxies can yield better results than using only one of the two types.

\subsection{CALIBRATION}

The aim of calibration is to determine the relation (response function, transfer function) between the proxy indicator (predictor) and the meteorological element (predictand) for the calibration period in which both values of the given proxy and the measured values of the meteorological element (such as sea surface temperature, land surface temperature, air pressure, precipitation) are available.

According to scientific standards the validity of any kind of data needs to be verified by applying suitable statistical methods and using independent data. For this reason series of intensity indices obtained from documentary evidence should overlap the period of instrumental measurements. However, the usual methods of calibration can rarely be applied in historical climatology. The reason is that in most cases the qualitatively best observers switched to instrumental observation when meteorological instruments became available at reasonable prices by about the mid-18th century. This modified the way in which they coined their weather descriptions. Therefore results from first class non-instrumental diaries rarely include the period of early instrumental observations (Pauling et al., 2003). A notable exception from this practice is an example from the Czech Lands, where systematic visual weather observations continued in parallel with early instrumental measurements at the station Prague-Klementinum, which has allowed validation of the descriptive weather reports (Brázdil et al., 2003a). Similarly, on the basis of visual observations at the Potsdam station it was shown that subjectively registered values have a high correlation with measured parameters (Werner and Gerstengarbe, 2003).

In order to statistically validate the indices a suitable approach has to be developed. This is documented here, using the example of winter and summer temperatures for Germany, Switzerland and the Czech Republic (Glaser et al., 1999b) (Tables II-IV). The first step shown was to find the correlation coefficients between real temperature series at four different sites and the series of intensity indices that were obtained from the same instrumental series. The high correlation coefficients in Table II demonstrate that indices can express the main features of temperature variability based on measured data for the selected Central European stations. The reduction of explained variance is only a few percent when transforming the instrumental readings into ordinal data. Thus, depending on the number of degrees of freedom in the chosen ordinal scale, real temperature variations are very well estimated by the indices. In a second step, the correlation between individual stations, both measured temperature and the index data derived from instrumental observations is 
TABLE II

Correlation coefficients between measured series and indexed series of air temperature for four Central European stations in 1901-1960 (all values are statistically significant at the 95\% level) (Glaser et al., 1999b)

\begin{tabular}{llllll}
\hline Stations & Winter & Spring & Summer & Autumn & Year \\
\hline Basel (Switzerland) & 0.89 & 0.91 & 0.91 & 0.93 & 0.92 \\
Frankfurt (Germany) & 0.89 & 0.91 & 0.93 & 0.93 & 0.87 \\
Potsdam (Germany) & 0.86 & 0.92 & 0.92 & 0.92 & 0.87 \\
Prague (Czech Rep.) & 0.89 & 0.93 & 0.90 & 0.89 & 0.87 \\
\hline
\end{tabular}

TABLE III

Correlation coefficients between measured series (M) and indexed series (I) of seasonal temperatures for four Central European stations in 1901-1960 (winter and summer) (all values are statistically significant at the $95 \%$ level) (Glaser et al., 1999b)

\begin{tabular}{llllll}
\hline \multicolumn{5}{c}{ Winter } \\
\hline Stations & Series & Basel & Frankfurt & Potsdam & Prague \\
\hline Basel & M & 1.00 & 0.92 & 0.79 & 0.85 \\
& I & 1.00 & 0.79 & 0.56 & 0.68 \\
Frankfurt & M & 0.87 & 1.00 & 0.93 & 0.96 \\
& I & 0.84 & 1.00 & 0.72 & 0.85 \\
Potsdam & M & 0.62 & 0.83 & 1.00 & 0.96 \\
& I & 0.64 & 0.72 & 1.00 & 0.84 \\
Prague & M & 0.77 & 0.87 & 0.87 & 1.00 \\
& I & 0.68 & 0.78 & 0.81 & 1.00 \\
\hline \multirow{5}{*}{ Summer } & TABLE IV &
\end{tabular}

Correlation coefficients between indexed series of seasonal temperatures for Germany, Switzerland and the Czech Republic during the 16th century (winter and summer) (all values are statistically significant at the $95 \%$ level) (Glaser et al., 1999b)

\begin{tabular}{llll}
\multicolumn{3}{c}{ Winter } \\
\hline Region & Germany & Switzerland & Czech Republic \\
\hline Germany & 1.00 & 0.68 & 0.79 \\
Switzerland & 0.75 & 1.00 & 0.59 \\
Czech Republic & 0.73 & 0.73 & 1.00 \\
\hline
\end{tabular}

Summer

calculated. Table III shows the summer and winter interstation correlations based on the reference period 1901-1960. In all cases the index series have lower interstation correlations than the instrumental series, which indicates that the index series have lower decorrelation length scales (Daley, 1993) than instrumental measurements. 
A comparison of these results with inter-country correlations between 16th century indices derived from documentary data for Germany, Switzerland and the Czech Republic (Table IV) shows similar magnitude and significance to those obtained in the modern period. However, these interstation correlations are perhaps artificially enhanced due to the fact that country average temperatures are used instead of individual station series. Nonetheless, it may be concluded that the reduction in correlation (for index data on an ordinal scale compared to instrumental data on a continuous scale) is rather small, which points to the spatial validity of the corresponding indexed series.

\subsection{VERIFICATION}

Prior to the reconstruction, the transfer functions have to be verified in a different time period, or at least a cross-validation procedure has to be carried out if the data series is rather short (Michaelsen, 1984). The relationship obtained in a calibration period is applied to a so-called verification period, for which the values of the meteorological element are estimated from the documentary data. These estimations are then compared with the measured values. Several verification tests developed for dendroclimatological reconstructions (see Cook et al., 1994) are also suitable for reconstructions based on documentary data. Other simple statistical measures, including for instance the correlation coefficient, the root-mean-square error and the $t$-test for the paired values, may be used to compare the measured and reconstructed values (see e.g. Brázdil and Kotyza, 2000). It is also advisable to investigate how the variability of the series obtained can be best expressed by the given transfer function. In view of the normally rather short lengths of both the calibration and verification periods in relation to the entire period for which the reconstruction is developed, it is practical and useful to exchange them and repeat the procedure before the next step.

\subsection{RECONSTRUCTION}

If the transfer function obtained expresses the variability of the meteorological element under consideration with satisfactory precision, the chronology of the proxy can be used for climatic reconstruction. The major problem of this reconstruction method is that the transfer functions, many derived from relatively modern periods, may be nonstationary, as is case with the NAO (Schmutz et al., 2000; Cook et al., 2002; Luterbacher et al., 2002a). It can be, for instance, a case that the phenological series were affected by changes in the crop mix, the introduction of new varieties of crops or by the introduction of harvest technology (e.g. combines) (Pfister, 2001). Also, local phenomena, like urbanisation, may interfere with the representativity of local data for regional variations. The problem of nonstationarity can be ameliorated 
by considering a sufficiently long calibration time period (Cook et al., 2002). It is therefore suggested to test the stationarity of the data used in order to assess the reliability of the transfer function (Rutherford et al., 2003).

\section{Recent Developments}

\subsection{NEW KINDS OF DOCUMENTARY DATA}

After 1990 the databases with documentary data existing in many European countries have been significantly extended with further weather notes from documentary evidence (e.g., for the 16th century, see Pfister et al., 1999a). Great progress was achieved, for instance, after the discovery of a great number of previously unknown weather diaries, its statistical analysis, graphical presentation on the basis of weather symbols and utilisation for assessing new series of indices (e.g. Tyrrell, 1995; Telelis, 1998; Brázdil and Kotyza, 1996, 1999; Pfister et al., 1999c; Börngen and Tetzlaff, 2000; Bokwa et al., 2001; Brázdil and Kiss, 2001; Limanówka, 2001). These daily records may be used effectively not only for detailed description of weather patterns for specific occasions in the past, but also for deriving monthly temperature and precipitation indices. Recently, Werner and Gerstengarbe (2003) showed that the frequency and type of precipitation and cloud cover for Potsdam, 1893-2000, characterise significant climatic variations and strongly confirm the results obtained from measured climatic parameters. This knowledge significantly enhances the potential of traditional visual daily weather records for climatic reconstructions.

Rodrigo et al. (1998) analysed climatic information in private correspondence of the Jesuit order in Castille (Spain) for 1634-1648. They showed prevalence of intense rainfall and cold waves in that period. Retsö (2002) used correspondence letters to characterise winter weather patterns from the early 16th century in Sweden.

In recent years the discovery of new data sources with climatological potential has facilitated further analyses in regions not previously investigated in detail. For instance, in Spain the Catholic Church organised rogation services (rogativas) directed to end climatic stress-situations connected with long dry ("pro pluvia" rogationes) or wet spells ("pro serenitate" rogationes) which jeopardised the crops (Martín-Vide and Barriendos, 1995). For droughts, the municipal and ecclesiastical authorities developed a system of activities in which five levels of rogationes can be distinguished. Level I was used as a preventative measure when drought had not yet exerted significant damage. Levels II and III were applied when the agricultural production had already suffered substantially. Levels IV and V were invoked when the entire crop was in jeopardy and the danger of subsistence crises were impending. Barriendos (1997) used rogation data for analysis of climate in the Iberian Peninsula in the period 1675-1715. Similar data about rogations from Erice (western Sicily) were used for the reconstruction of drought spells during 
the period 1565-1915 (Piervitali and Colacino, 2001). Rodrigo et al. (1999, 2001) used, among other documentary sources, religious chronicles, and books of city and church archives in order to reconstruct the seasonal precipitation variability in southern Spain (Andalusia) and the winter North Atlantic Oscillation back to AD 1500.

Some documentary data have long been recognised as potential climatic indicators. For example, Brückner (1890) used the dates of freezing of rivers and water bodies as a useful index for winter temperature conditions. Camuffo (1987) studied freezing of the Venetian Lagoon since the 9th century in relation to winters in Western Europe and England. Kajander (1993) reconstructed a series of ice break-up dates for the Tornio River (the border between Finland and Sweden) for 16931993, based on different documentary data. They correlate very well with local mean April-May temperatures and show that the ice break-up occurs on average thirteen days earlier now compared to the Maunder Minimum period, which corresponds to a mean warming in April-May by about $2{ }^{\circ} \mathrm{C}$ (Klingbjer and Moberg, 2003). Ogilvie (1996) analysed sea-ice conditions along the coast of Iceland for 1601-1850. Koslowski and Glaser (1999) developed a winter ice index with integer values, from 0 (no ice) in warm winters to 3 (continuous ice) in severe winters for the western Baltic Sea for the period 1501-1995. Figure 3 displays remarkable periods of severe winters in the 1510s, around 1570 and 1600, between 1615 and 1625 , in the 1660s, in the 1690s and around 1800. Jevrejeva (2001) and Jevrejeva and Moore (2001) used many historical chronicles of break-up dates at Riga to reconstruct the winter sea ice severity in the northern Baltic Sea back to the early 16th century.

Economic information, mainly about harvest and vintage, are traditional sources of data in historical climatology (e.g., Pfister, 1979, 1981; Le Roy Ladurie and Baulant, 1980; Lauer and Frankenberg, 1986; Glaser, 1991; Souriau and Yiou, 2001). Some new evidence of economic character has appeared in Europe after 1990. Tarand and Kuiv (1994) used series of the beginning of the rye harvest in the regions of Estonia, Latvia and Finland for reconstruction of the mean April-July temperatures in the period 1671-1949. Later this data, together with the first day of ice-break up in Tallin port and on the rivers in northern Estonia, was used for reconstruction of the Tallin temperature series (Tarand and Nordli, 2001). De Kraker (1999) utilised data from accounts of dikes protecting a polder region in northern Flanders as proxy for the study of the occurrence of high tides, storms and storm surges in the period 1488-1609. Later he extended this study on the period from AD 1000 up to the present (de Kraker, 2002). Camuffo et al. (2000) analysed long series of sea storms since the 8th century in the Adriatic Sea and Western Mediterranean which caused widespread devastation in Venice and Barcelona. Střeštík and Verö (2000) showed significant correlation between the length of new grapevine sprouts measured systematically since 1740 in Köszeg (Hungary) and March-April temperatures. Nordli (2001) used dates of crop sowing from farmers' diaries for reconstruction of April-August average temperatures in Norway and for testing local 
instrumental temperature records from the 19th century. In the another investigation, Nordli et al. $(2002,2003)$ compiled a series of April-August temperatures of Vestlandet (western Norway) for 1734-2002 combining instrumental data, grain harvest dates and dated terminal moraines of the glaciers Nigardsbreen and Storbreen.

Climatic information can also be derived from economic data concerning taxation. Grove and Battagel (1983), analysing data from general tax commissions from Sunnfjord Fogderi (Norway), found a substantial decline in rural prosperity between 1667 and 1723. This is documented in tax relief proceedings connected with serious physical damage (floods, avalanches, landslides). Documentary sources of cereal taxes collected in the Canary Islands have been used to construct a complete and reliable wheat and barley production series for the period 1595-1836 (García et al., 2003). The cereal growth period in this region, including the months OctoberMarch, covers the whole rainy season in the islands, making these crops adequate to characterise the precipitation at annual scales. Brázdil and Valášek (2003) and Brázdil et al. (2003b) showed the potential of records of tax reduction to study past meteorological and hydrological extremes and their impacts.

A new kind of para-phenological indicator, similar to vine harvest dates, was discovered for Switzerland by Pfister (1979). Prior to the grain harvest, the tithe to be paid in grain had to be assessed for fiscal reasons. It was then sold by auction to wealthy farmers who had to bring the amount of grain purchased to the barn of the bailiff after threshing. The date of the auction immediately preceded the harvest and it can be used as a reliable proxy for the timing of the harvest. Highly significant correlations were found with temperature in May and June (Pfister, 1979). Recent investigations have shown that tithe auctions were also common in Austria and in Germany (Bauernfeind, 1993; Egger and Weigelt, 2000).

Another proxy indicator was recently discovered in the account books of the town Louny in north-west Bohemia (the Czech Republic). The account kept track of wages paid by the municipality on Saturday for work carried out in the preceding week. As this list is very detailed, it also relates to work that depended on weather and climate, e.g. cutting ice at the water mills and on the Ohře River, cleaning snow from the roads, repairing bridges after floods etc. The references to the harvest are particularly conclusive, because they are connected to the ripening of grain and thus to the temperature patterns in the months preceding the harvest. Brázdil and Kotyza (2000) have drawn on this proxy evidence to reconstruct winter and springsummer temperature patterns in the Czech Lands over the period 1450-1632 (with some gaps). Autumn is less densely documented than the other seasons, because the climatic conditions had a smaller impact on traditional societies at this time. However some climatic information can be drawn from the sugar content of wine, in order to assess warmth and sunshine in September (Pfister, 1984). It is assumed that similar results presented in Brázdil and Kotyza (2000) might be obtained from the account books of many other towns in Central Europe and beyond.

Information derived from ship logbooks is another important source of evidence. This may greatly increase our knowledge of conditions over sea and ocean areas, 
in particular the prevailing winds that, in most weather diaries are recorded but not very consistently. A great abundance of naval logbooks are known to exist in the marine archives of the ancient great Powers, but only a tiny fraction of these sources have been investigated so far. For instance, Wheeler (1995) analysed weather records in the logbooks of Nicholas Pocock for 1766-1776. Frydendahl and Frich (1996) collected more than 50,000 observations of wind direction and force from logbooks in the Øresund area for the period 1675-1715. The authors concluded that the frequencies of northerly and north-westerly wind directions were higher and the winds stronger than in the modern period 1951-1980. García et al. (2000) estimated atmospheric circulation in the North Atlantic in the periods 1551-1650 and 1717-1737 based on sailing times of the Spanish ships to America. Historical accounts of the voyages of the Manila galleons were used for the study of changes in the atmospheric circulation of the tropical Pacific Ocean during the 16th-18th centuries (Garcia et al., 2001). In addition, the logbooks' information might be effectively used for description of weather patterns of important historical events such as the Battle of Trafalgar in 1805 (Wheeler, 2001) or during the voyage of individual ships (e.g. Wheeler, 2003). Further progress is expected from the EC Framework V project 2000-2003 called CLIWOC (Climatological database for the World's oceans 1750-1850 - see http://www.ucm.es/info/cliwoc) which is trying "to realise the scientific potential of logbook climatic data and to produce a database of daily weather observations for the world's oceans between 1750 and $1850 "$.

From the previous overview it follows that research in historical climatology in Europe is geographically unbalanced. Although some potential of different kinds of documentary evidence exists more or less in the every European country, only some have been used in systematic historical-climatological investigations (such as the Czech Republic, England, Germany, Hungary, Italy, the Netherlands, Norway, Poland, Spain and Switzerland). Further studies from other countries in the Adriatic region (Penzar and Penzar, 1997) and the territory of Austria (Strömmer, 2003), Crete (Grove and Conterio, 1995), Greece (Repapis at al., 1989; Xoplaki et al., 2001), the Italian Alps (Bonardi, 1996, 2000), Slovakia (Brázdil and Kiss, 2001), Slovenia (Ogrin, 2002), Romania (Cernovodeanu and Binder, 1993) and Russia (e.g. Borisenkov and Pasetskiy, 1988; Borisenkov, 1992; Lyakhov, 1992; Chernavskaya, 1995; Popova, 2001) are needed to help resolve finer spatial and temporal scales of past climate variability. Hitherto the availability of such dense and rich data sets has allowed very accurate climate reconstructions in the Atlantic-European area for the last several centuries (Luterbacher et al., 1999, 2000, 2002b, 2004).

\subsection{REORIENTATION TOWARDS A SYNOPTIC VIEW}

Most of the climate reconstructions over say the last 1000 years focus on temperature (e.g. Bradley and Jones, 1993; Briffa et al., 1998, 2001; Mann et al., 1998, 
1999; Crowley, 2000; Crowley and Lowery, 2000; Jones et al., 2001; Mann, 2001; Briffa and Osborn, 2002; Esper et al., 2002). This fact hinders a detailed dynamical analysis of atmospheric processes as it is known from studies based on reanalysis data or long model integrations. Even the sparse data make it difficult to reconstruct the important state variables such as radiation, surface temperature, air pressure, wind, humidity and precipitation. Future studies have to pursue this goal. It is one of the merits of historical climatology to try to extend the number of analysed parameters in order to get a better understanding of past synoptic processes and regimes in this way. At this stage only some of these elements have been reasonably well reconstructed (Wanner and Luterbacher, 2002).

Significant progress, however, has been made in reconstructing the variations of relevant time-variable forcing factors like the atmospheric load of volcanic aerosols and the output of the sun (Crowley, 2000). These variations may be fed into different types of physical climate models (energy balance, radiative-convective or GCMs), which can be used to estimate the response of the climate system to variable external forcing and thus provide a first guess of how the climate actually may have varied (for an example, see Section 5.7). However, since the climate state is composed of an externally forced deterministic component and a stochastic part related to internal dynamics of the climate system, the exact historical state can not be simulated with very high precision. The application of data assimilation methods (e.g., Robinson et al., 1998) such as DATUN (von Storch et al., 2000) can help to improve their precision. The first attempts to reconstruct average seasonal atmospheric pressure at sea level using different documentary evidence from the Atlantic-European region were made by Lamb (1987). Such reconstructions were based on the assumption that anomalies in temperature and precipitation must be related to circulation fluctuations caused by changes in the positions of the prevailing pressure systems and lower tropospheric advection of typical air masses (as reflected, e.g., by the fluctuations of the NAO index). Circulation patterns during months with pronounced temperature and/or precipitation anomalies during the instrumental period can, to a certain extent, be used as analogues for similar anomaly patterns in the past (Jacobeit, 1997). Extension of the data base related to documentary data in the 1990s (Pfister et al., 1994) has made it possible to identify more reliably circulation changes in terms of mean monthly sea level pressure (SLP) maps. Such maps have been developed for the Late Maunder Minimum period (1675-1704) by Wanner et al. $(1994,1995)$. Similar to the reconstructions by Lamb (1987), they are subject to the disadvantage that they cannot be tested statistically since the subjective maps are representing prevalent conditions rather than real monthly means (Jacobeit et al., 1999); prevalent characteristics, however, disregarding intermediate deviations, might be smoothed out if integrated into strictly mean conditions as in the objective grids. Further, subjective maps might suffer from some overestimation since descriptive informations often tend to emphasize anomalies. Objective reconstructions are more approaching mean conditions, thus being more consistent with recent reference data. On the other hand, with only few 
data for statistical reconstructions, resulting grids tend to diminish in variability and subjective maps based on documentary sources might better succeed in reproducing distinct circulation patterns, at least for outstanding anomalies with sufficient descriptive information (Luterbacher et al., 2002b).

Attempts to compare circulation patterns in the 16th century with the 20th century analogues for selected cold and warm winters and summers have been made by Jacobeit et al. (1999). Statistically improved mean monthly SLP maps for the Late Maunder Minimum period (1675-1715) were later reconstructed by Luterbacher et al. (2000). This reconstruction, utilising both proxy and instrumental records, was based on a canonical correlation analysis (CCA), with the standardised station and documentary data as predictors and the SLP fields as predictands. In a more recent paper, Luterbacher et al. (2002b) used a principal component regression analysis to reconstruct gridded SLP for the eastern Atlantic-European area. Based on early instrumental measurements and intensity indices derived from documentary evidence, seasonal (1500-1658) and monthly (1659-1999) SLP was reconstructed and subsequently used for an EOF analysis. Figure 4 shows the first three EOFs of winter SLP anomalies from 1500 to 1999 and their associated score series. The first pattern represents the classical zonal or NAO like structure, the second shows a large pole east of Great Britain, and the third one depicts the classical meridional flow situation over Europe. The first NAO like pattern accounts for 55\% of winter SLP variance. Its time series shows a high variability with a mixture of positive and negative values before 1950 but mostly highly positive ones during the last 30 years, a fact which is well known from many NAO studies (Wanner et al., 2001). The combination of such pressure reconstructions with temperature and precipitation data will not only form an excellent basis for model validation, it will also lead to a better understanding of the dynamical processes for earlier centuries (Wanner and Luterbacher, 2002). It has been demonstrated by Zorita and González-Rouco (2002) that the converse is also true and that models can be used to investigate the reliability of reconstructions. As mentioned in Section 4.4, a major limitation of reconstruction methods is the possible non-stationarity of the transfer function. Zorita and González-Rouco (2002) have used output from a long GCM integration to generate 'pseudo-proxy' data. They showed that the time-series behaviour of reconstructed meteorological elements are dependent on the used training (calibration) data set. Sometimes large biases can occur.

\subsection{DEFINING THE MEDIEVAL WARM PERIOD AND THE LITTLE ICE AGE}

The climate of the last millennium, not only in Europe but also in other regions, has traditionally been thought of as a time span including a "Medieval Warm Period" (MWP), followed by a period of climatic deterioration, a "Little Ice Age" (LIA) and the current warming phase. Lamb (1965, 1977, 1984), based almost solely on evidence from Western Europe and the North Atlantic region, placed the MWP 

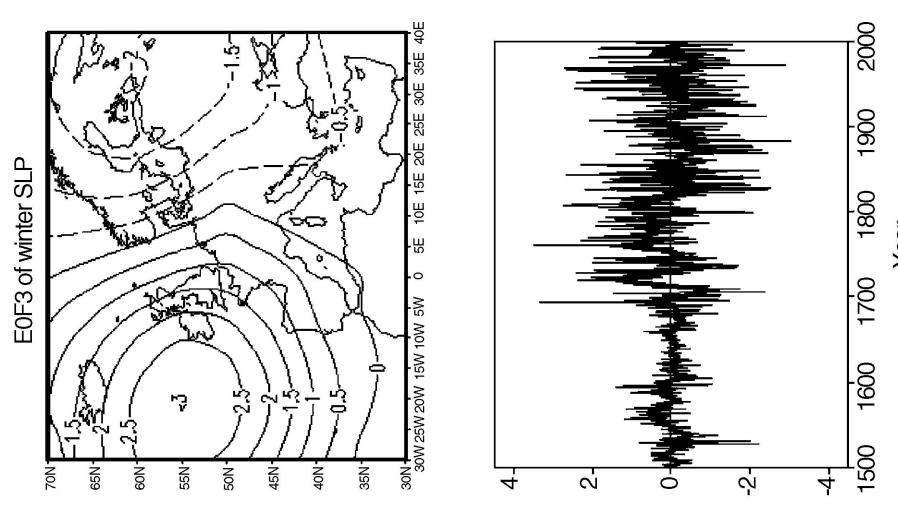

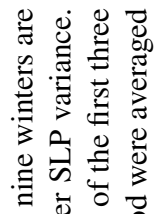

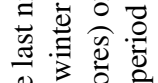

E 巳

$\dot{x}$ 范

긍

ॠ

过苋过

$\Xi 2 . \Xi$

응

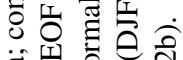

를 잉ㅇㅇ
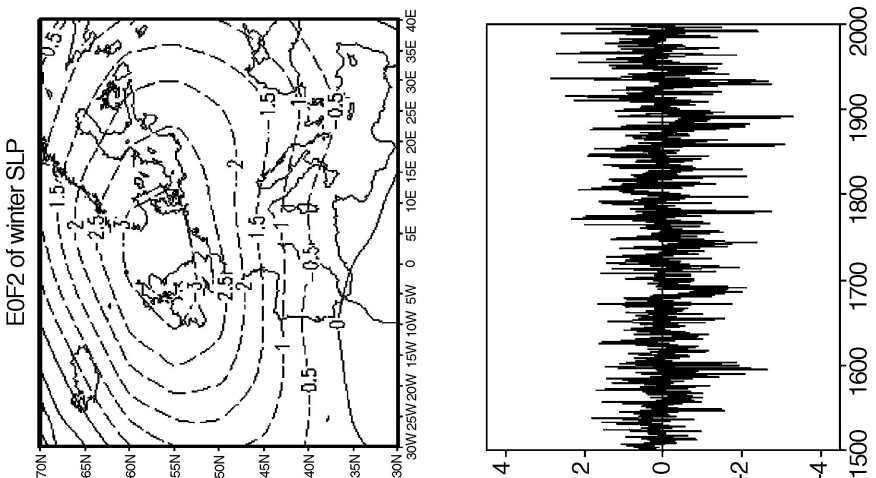

范

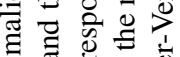

芩० 000

슈

इे छ

ठํ

용

。ำ

的文范

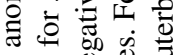

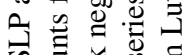
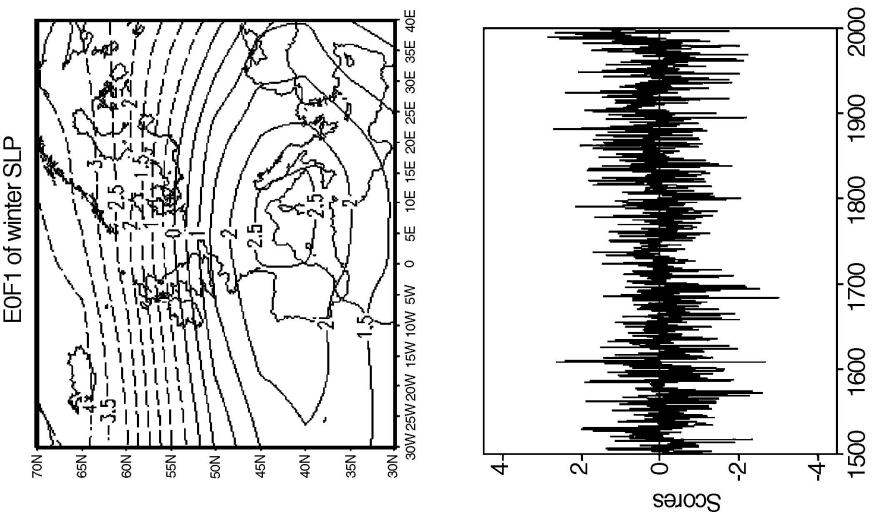

ธठํㅀ

$\Xi \pm$ उั

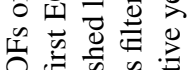

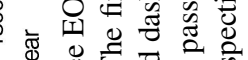
巳 可的艺 율월 눙

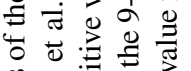

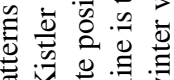

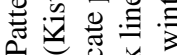

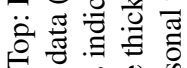

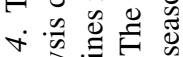

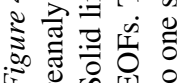


in the period 950-1200 (but in 1150-1300 for the greater part of Europe), and the LIA in 1550-1850, with the most pronounced phase in the period 1550-1700. These terms have commonly been used not only by climatologists but also by those working in related sciences (e.g. Appleby, 1981; Chernavskaya, 1992; Fagan, 2000; Buckland and Wagner, 2001; Kociánová, 2002). Many books and proceedings have been devoted to climate especially during the MWP and the LIA (e.g., Grove, 1988; Bradley and Jones, 1992; Mikami, 1992; Hughes and Diaz, 1994a; Jones et al., 1996; Fagan, 2000; Ogilvie and Jónsson, 2001).

This schematic division of the last millennium directed research in historical climatology to the analysis of these periods (e.g. Lamb, 1980; Rodrigo et al., 1995). However, from recent analyses it is concluded that the timing of these key periods primarily depends on the availability and the time resolution of proxy data and of the regional setting. More recent research has reassessed this paradigm (Bradley, 2000; Bradley et al., 2003; Soon and Baliunas, 2003). For instance, while Lamb (1977) placed the start of the "Little Ice Age" in the mid-16th century, Porter (1986), on the basis of glacial studies in the Northern Hemisphere, considered that it had already begun around AD 1250. Fluctuations of the longest Alpine glacier, the Great Aletsch glacier, included during the last millennium a smaller advance at about AD 1120 and three extreme maxima around AD 1350, 1650 and 1860 (Figure 5). However, the maximum in 1350 is only radiocarbon dated and a substantial dating error, in the order of tenths years has to be allowed for. On the other hand, the corresponding advance of Gorner glacier (Canton of Valais, Swiss Alps) has been dendrochronologically dated by a more reliable method. This glacier reached a maximum around 1385 (Holzhauser, 1997, 2002; Holzhauser and Zumbühl, 1999) which agrees well with the available documentary evidence (Pfister, 1988a). Jones and Bradley (1992) avoided defining universally applicable dates for the onset and end of the LIA due to great regional variations. Based on documentary evidence,

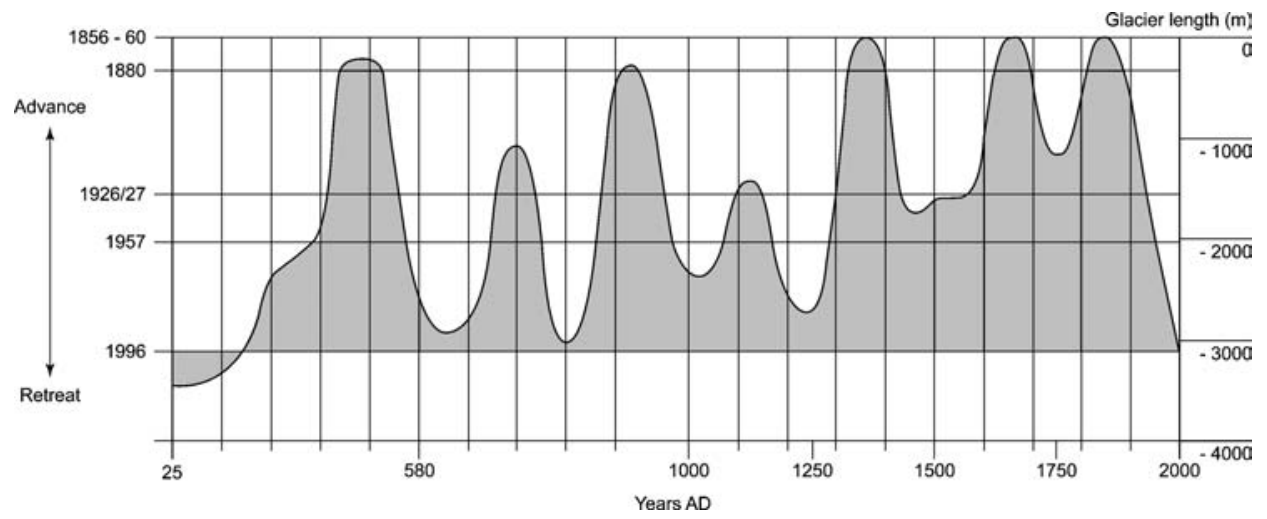

Figure 5. Fluctuations in the length of the Grosser Aletsch glacier (the Alps, Switzerland) in the last 2000 years (corrected according to Holzhauser and Zumbühl, 1999). 
Pfister et al. $(1996,1998)$ concluded from analyses of winter temperature proxies that the LIA started in Central Europe shortly after AD 1300.

Similar inconsistencies are related to the term "Medieval Warm Period" (Hughes and Diaz, 1994a), where the evidence compared to the LIA is scarcer. After compiling existing knowledge about the MWP, Hughes and Diaz (1994b) judged that "it is impossible at present to conclude from the evidence gathered here that there is anything more significant than the fact that in some areas of the globe, for some part of the year, relatively warm conditions may have prevailed ... the available evidence does not support a global Medieval Warm Epoch ...". Besides the discussion of whether the MWP had a global extent (Broecker, 2001), it is generally believed that, in the hemispheric scale, temperatures were not higher than during the second part of the 20th century (Crowley and Lowery, 2000). Similarly, according to Bradley et al. (2003) the balance of existing evidence does not point to a high medieval period that was as warm as or warmer than the late 20th century. Ogilvie et al. (2000), after combining documentary evidence with proxy data from natural archives such as ice cores and marine sediments, speaks about favourable conditions in the North Atlantic region during AD 800-1100 (without danger of sea ice) that allowed Vikings to explore and inhabit Iceland, Greenland and Newfoundland (so-called "Vínland"). Temperatures in this region were higher during AD 8001100 than in the following centuries, but not more than $1-2^{\circ} \mathrm{C}$. Esper et al. (2002), analysing selected tree-ring chronologies from 14 sites in the Northern Hemisphere extratropics, found that the MWP may have begun there in the early 900s. In their reconstruction, the warmest period covers the interval AD 950-1045 with a peak around 990 (for the MWP in Eastern Mediterranean see also Telelis, 2000, 2004).

The concepts of the MWP and LIA have also been discussed in other terms than temperature only. According to Grove (2001a, 2001b) the term "Little Ice Age" relates to the dimension of glaciers rather than directly to climate (see also Matthes, 1939, 1940). The "Little Ice Age" was the most recent period during which glaciers maintained an expanded position in most parts of the globe, with their fronts oscillating around advanced positions. These fluctuations resulted from a combination of changes in seasonal temperature and precipitation patterns, but according to Grove $(2001 \mathrm{a}, \mathrm{b})$ the LIA is not a climatic term as such. Stine (1998), based on his drought studies from the Western United States, proposed another term for the overall period of the MWP as the "Medieval Climatic Anomaly" (MCA), which removes the emphasis on the temperature. Wanner et al. (2000) have coined the term of "Little Ice Age Type Events" (LIATES) for the phases of glacier advance. Consequently, the "Medieval Warm Period" can be defined as the period between the glacial advances of the LIA and a preceding phase of glacial expansion late in the penultimate millennium (see Figure 5) (Grove and Switsur, 1994). In this warmer period, climatic conditions caused glacier mass balances to be negative, and volumes of glaciers to be reduced, so that their fronts melted back substantially, albeit with minor variations. In the light of the recent discussion about greenhouse 
gas induced global warming an elucidation of the processes that led to the MWP is a research topic with high priority. It needs to be stressed that neither the MWP nor the LIA were periods of unbroken warm or cold climate respectively (Wanner et al., 2000; Grove, 2001a,b). The distinct problem is further accentuated by the estimates of Northern Hemisphere (NH) annual mean temperatures since AD 1000 reconstructed by Mann et al. (1999) from different proxy series (tree rings, ice cores, documentary evidence, corals). This series shows a gradual decline of temperatures over the last millennium (no sudden onset of the LIA) and a dramatic increase during the 20th century with the warmest decade in the 1990s and 1998 as the warmest year (Figure 6).

The climate variability of the NH is considerably different to that of European climate variability reconstructed using documentary evidence. Guiot (1992) developed series of European temperature anomalies for AD 1068-1979 based on documentary and biological evidence (Figure 6). This series represents the average over 20 reconstructed gridpoints covering the area $35^{\circ} \mathrm{N}-55^{\circ} \mathrm{N}$ and $10^{\circ} \mathrm{W}-20^{\circ} \mathrm{E}$. Luterbacher et al. (2004) recently developed highly resolved spatio-temporal temperature reconstructions for European land areas back to AD 1500. Their estimates were obtained utilising a multivariate statistical approach combining long instrumental temperature and pressure series, documentary proxy data and for the earlier period (before 1659) a few seasonally resolved temperature proxy reconstructions from Greenland ice cores and tree ring data from Scandinavia and Siberia. The annual anomalies of the results of both studies are compared in Figure 6 using the same geographical area as Guiot (1992).

As expected, in the common period of all three series 1500-1979 the correlation of the unfiltered data is highest between the two European series (0.54). However, it has to be born in mind that the rather high correlation between the two European series is inflated due to several common predictors (e.g. the Central England temperature series, temperatures from Switzerland). Luterbacher et al. (2004) used more predictors than Guiot (1992), including many homogenised temperature and pressure series from different sites in Europe (mainly since the early-18th century). Furthermore, they used documentary proxy evidence from different European places that were not available to Guiot (1992) and the new reconstruction is based on $0.5 \times 0.5$ degree grid boxes (i.e., resolution around $60 \mathrm{~km}$ over land), which provides more regional details. Moreover, the new reconstruction was made on monthly (back to 1659) and seasonal (1500-1658) level. Summarising these facts, Luterbacher et al. (2004) used much more data than did Guiot (1992), which allows a more skilfull reconstruction. The new reconstruction is more highly resolved both in time and space, allowing the study of regional monthly and seasonal temperature changes and extremes, which are not visible on the annual level.

The similarities between the NH series of Mann et al. (1999) and the two European temperature estimates are, as expected, weaker. The corresponding correlations for annual unfiltered values are 0.32 (Luterbacher et al., 2004) and 0.21 (Guiot, 1992) respectively, both significant at the $99.9 \%$ level. Though highly 

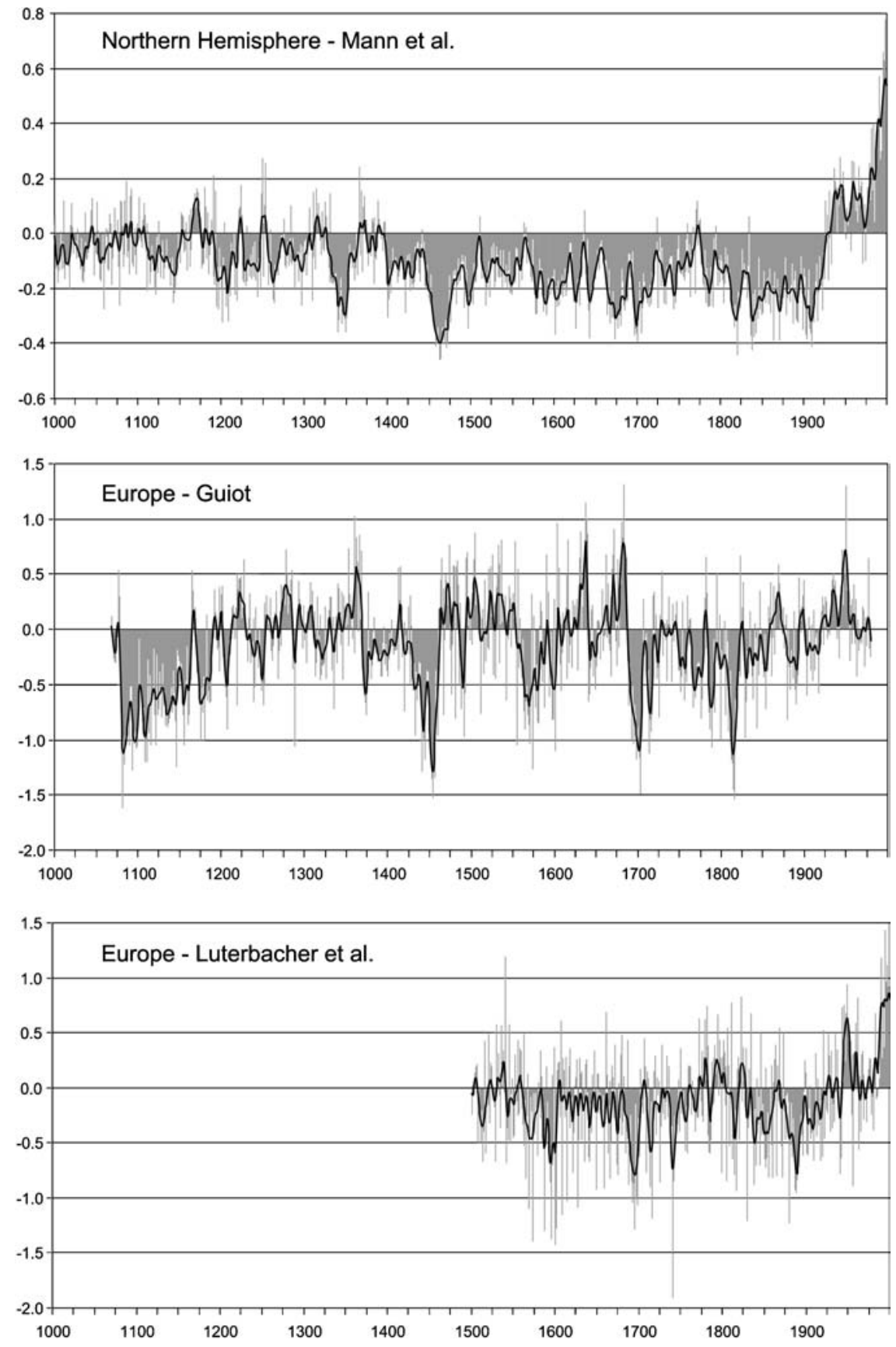

Figure 6. Fluctuations in annual Northern Hemisphere (Mann et al., 1999) and European temperature anomalies $\left({ }^{\circ} \mathrm{C}\right.$ ) according to Guiot (1992) and Luterbacher et al. (2004) during the last millennium. Reference period 1902-1980 for Mann et al. (1999) and Luterbacher et al. (2004) and 1851-1979 for Guiot (1992). The three time-series have been smoothed by a 10-year Gaussian filter. The scale for Northern Hemisphere temperature is different from both European series. 
significant, only between 4 and $9 \%$ of common variability is shared between the European and the Northern Hemisphere annual temperature reconstructions. It should be mentioned that the European reconstructions are not fully independent from the reconstruction of Mann et al. (1999) as they share some basic data; hence the correlations may be an overestimate.

It is obvious that a temperature reconstruction for Europe must exhibit notable differences compared to a $\mathrm{NH}$ reconstruction as Europe is only a small part of the entire hemisphere. Nevertheless, instrumental data for the last 140 years (Hansen et al., 1999, 2001) reveal a relatively strong connection between the NH land temperature north of $20^{\circ} \mathrm{N}$ and European land areas $\left(25^{\circ} \mathrm{W}-40^{\circ} \mathrm{E} ; 35^{\circ} \mathrm{N}-70^{\circ} \mathrm{N}\right)$. The correlation is 0.62 for winter and reaches 0.75 for summer and the entire year. The correlations between the proxy-data-based reconstructions for Europe (Guiot, 1992; Luterbacher et al., 2004) and that for the NH (Mann et al. 1999) reveal a markedly weaker relationship compared to that found in the instrumental data. This can mainly be attributed to uncertainties in the reconstructions, but could also partly reflect different de-coupling and climate behaviour at the continental scale compared to the entire $\mathrm{NH}$.

A striking feature (Figure 6) is the significantly greater variability on almost all time scales in case of the European temperature reconstructions compared to the $\mathrm{NH}$. This may be, amongst other factors, due to certain types of signals (e.g., the influence of climate forcings such as volcanic, solar, internal oscillations) which are stronger in the European reconstructions than on the Northern Hemisphere scale.

Pauling et al. (2003) investigated the importance of proxies for seasonal European and North Atlantic temperature field reconstructions. Their study analysed the importance of several different types of proxy series for the reconstruction of climate in different parts of Europe, allowing for 'teleconnections' between the geographical location where the proxy data was collected and the part of Europe for which temperature is reconstructed. For boreal winter (October-March) they found that documentary evidence was most important for much of continental Europe, while a speleothem from Scotland was the most important proxy (among those used in the analysis) for both Iceland and the western Mediterranean region. Tree-ring data had most importance both for the eastern Mediterranean and parts of northern Fennoscandia. For summer temperature reconstructions, tree-ring data had the largest importance for most of Europe, while documentary data and the Scottish speleothem had relevance for various smaller parts of Europe. These findings can, however, not be generalized as they refer only to the actual selection of proxy data analysed. Once new proxy data are becoming available, it may turn out that these will be more important for some regions than, for example, the Scottish speleothem.

Based on various types of proxy data, Bradley and Jones (1993) calculated an average series of summer temperature anomalies for Europe since AD 1400 (Figure 7). This series shows, for decadal values in the common period of 15001979, statistically significant correlations with the reconstructed summer temperatures of Prague in the Czech Republic (0.49) and Switzerland (0.39), while the 

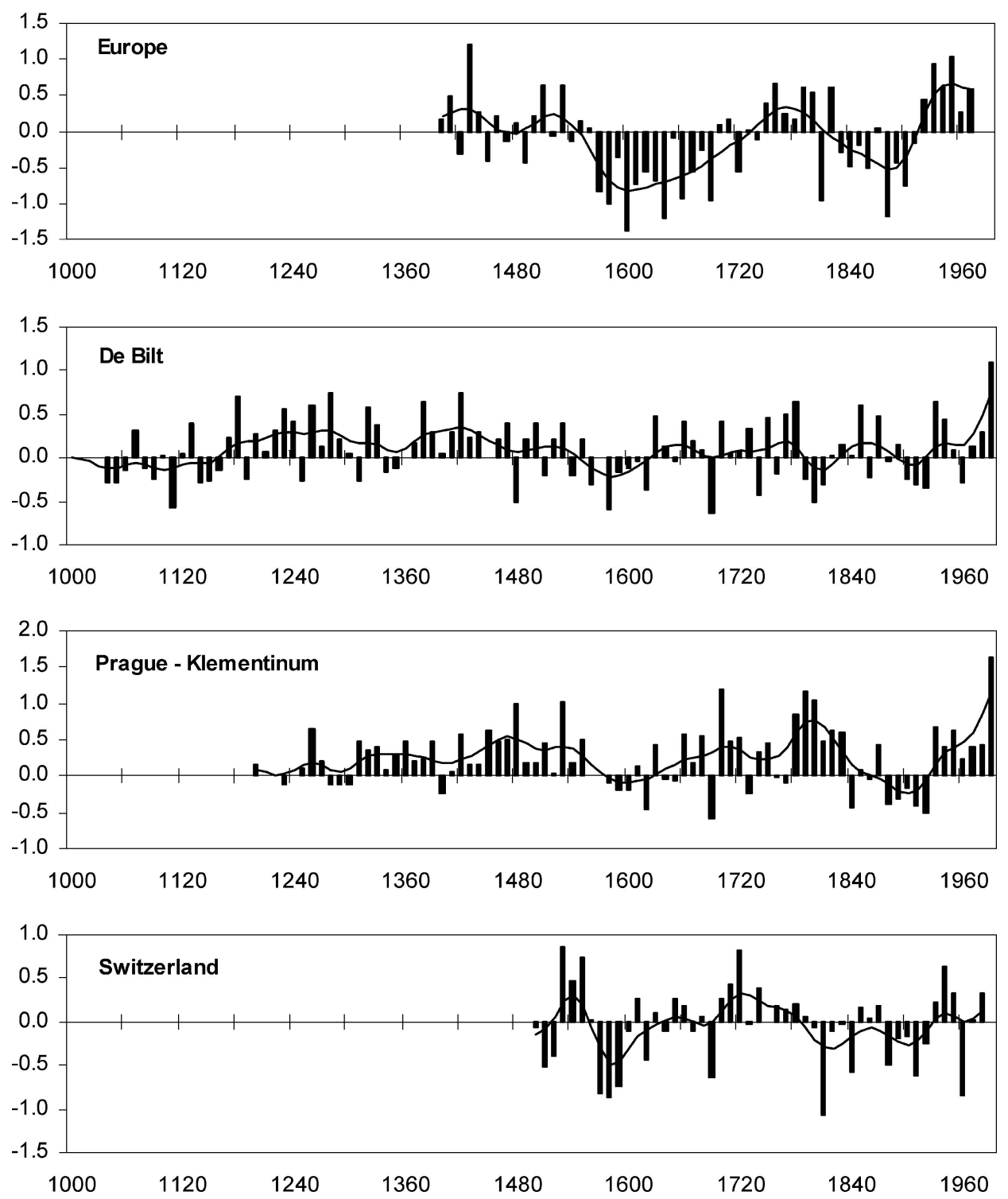

Figure 7. Fluctuations in decadal anomalies of summer temperatures $\left({ }^{\circ} \mathrm{C}\right)$ in Europe over the last millennium (reference period 1901-1960), smoothed by a 10-decade Gaussian filter): (a) Europe (Bradley and Jones, 1993), (b) De Bilt - the Netherlands (van Engelen et al., 2000, 2001), (c) PragueKlementinum - the Czech Republic (Brázdil, 1996), (d) Switzerland (Pfister, 1999).

correlation with the station De Bilt in the Netherlands (0.25) is not significant. The Czech Republic series and the De Bilt series were not used in the European series by Bradley and Jones (1993), but the latter included the Swiss series. In the modern period 1900-1979, the correlations with the Bradley and Jones (1993) series are much stronger ( 0.65 for De Bilt, 0.54 for Switzerland, 0.70 for the Czech 
Republic). These results show that significant correlations exist between reconstructions of some local to regional Central European series and the European average, but they also show that the correlations can vary substantially in time - indicating time-varying reliability of the reconstructions.

Recently, Jones et al. (2003a) using both long European instrumental records and longer European and Chinese documentary series showed that winters have warmed relative to summers over the last 200 years compared to earlier in the past millennium. They concluded that it may give erroneous indications of the past, if proxies that are indicative of summer conditions are used to reconstruct annual mean temperatures. This could potentially be a serious problem, as many natural proxy data are sensitive to summer conditions while relatively few are sensitive to winter and the other two seasons.

Detailed studies of climate fluctuations and their spatial structure in Europe, based mainly on documentary evidence, have been undertaken for the 16th century (Pfister et al., 1999a) and for the Late Maunder Minimum period in 1675-1715 (e.g. Frenzel et al., 1994; Barriendos, 1997; Alcoforado et al., 2000; Xoplaki et al., 2001). Apart from temporal reconstructions for Germany (Glaser et al., 1999a) and the Low countries (van Engelen et al., 2000, 2001) there are no other European temperature reconstructions with annual resolution available since AD 1000. The challenge remains to assess temperature series for Central Europe over the last millennium using data and reconstructions from other countries.

\subsection{CLIMATIC ANOMALIES AND NATURAL DISASTERS}

The terms "climatic anomaly" or "extreme event" are used here to describe a substantial deviation of a single value in a time series from an arithmetic mean or from a trend, i.e. in association with short-term events (Pfister, 1999). On the other hand the term "natural disaster" focuses on the effects of extreme events upon human societies. In other words, whether a rare event becomes a disaster depends on the social conditions. Disasters are classified both in terms of material (money equivalent) and immaterial damages (i.e. victims). However, the helplessness of the victims, their dependence on help from the outside, provides a common denominator (Pfister, 2002).

In the context of the enhanced greenhouse effect debate, the potential anthropogenic influences on climate are often blamed for environmental risks, in particular climatic anomalies and natural disasters (Stehr and von Storch, 1995; Ungar, 1999). While weather extremes usually have immediate consequences, the effects of climatic anomalies may be time lagged. This was demonstrated by Pfister's (1999) study of anomalies in monthly temperature and precipitation in Switzerland during the period 1496-1995, which took into account occurrence of warm or cold, dry or wet conditions, and their combinations. In the period 1560-1895, overlapping for the most part with the LIA, $71 \%$ of anomalous months were cold, of these $40 \%$ were 

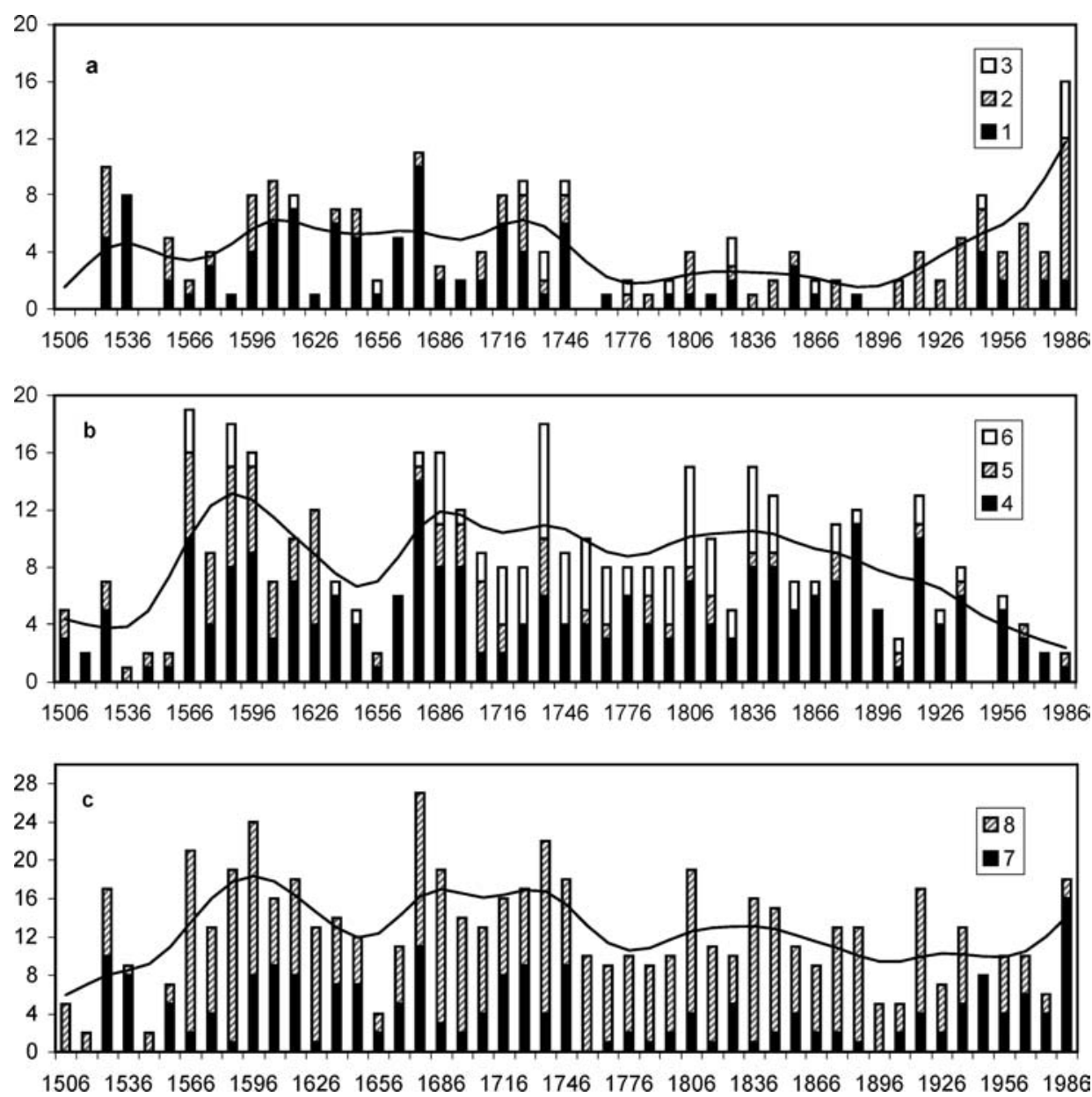

Figure 8. Decadal frequencies of warm (a), cold (b) and warm + cold (c) monthly temperature anomalies in Switzerland in the period 1506-1995 (data in Pfister, 1999): 1 - warm, 2 - warm-dry, 3 - warm-wet, 4 - cold, 5 - cold-wet, 6 - cold-dry, 7 - warm, warm-dry, warm-wet, 8 - cold, cold-wet, cold-dry. Smoothed by a 10-decade Gaussian filter. Years on the $x$-axis always mean the first year of the respective decade (Brázdil, (C) Springer-Verlag 2002).

rated cold, 17\% cold-dry and 14\% cold-wet. Between 1896 and 1988 the proportion of months that were anomalously cold dropped to 56\%, while between 1988 and 1997 cold anomalies completely disappeared. Figures 8a and 8b show decadal frequencies of individual months classified as warm (a) and cold (b) anomalies. More pronounced climate variability from the latter half of the 16th century to the mid-18th century is evident in Figure 8c, which shows the total frequency of both warm and cold anomalies combined.

Natural disasters have always affected human affairs to some degree, as they do at the present time, when the material damage they cause is increasing and more 
devastating. In the world, the material damage has grown by a factor of fourteen between the 1950s and the 1990s. Most, if not all of this increase, are the result of a greater intensity of settlements and constructions in potentially dangerous areas (Münchener Rück, 1999). The issue of whether the number and severity of "extreme events" has increased as a result of the enhanced greenhouse effect is highly controversial. In particular the following issues are not settled (Karl and Easterling, 1999):

(i) Whether the observed process of global warming is projected to the frequency and intensity of meteorological extremes.

(ii) Whether and to what extent the human society becomes more sensitive to impacts of meteorological extremes.

(iii) Whether the perception of meteorological extremes is to a greater extent affected by media.

Accurate observations (comparable to the modern standard) of meteorological extremes (e.g. gales, hailstorms, tornadoes) and hydrological extremes (e.g. floods) are, as a rule, bound to the period in which the given element or phenomenon was systematically observed within a network. This period rarely extends over more than hundred years. Documentary data are the only kind of evidence that allows pushing back the record of such extremes into the past for several more centuries. The more extreme an event, the more evidence are available and the more detailed they are providing information about their intensity, seasonality, causes and impacts of disasters (Pfister, 1999; Brázdil, 2000). Moreover such reconstructions may at least partly provide analogue-cases for the present.

Certain limitations of this kind of evidence, however, have to be kept in mind. It is spatially and temporally discontinuous and limited to those events that had a significant impact on society. For the Czech Republic a series of strong wind events based on documentary evidence has been compiled since AD 1500 (Figure 9). Two periods before 1900 stand out in which such events were particularly frequent: The first one is the 1580s-1590s (also the 1640s), the second is the time between 1770 and 1900. It is open to debate whether such fluctuations are rather an effect of a changing density of records than the product of changing climate parameters. A conspicuous increase in frequencies since 1900 is due to a systematic research of newspaper reports, whereas up to that time the data were obtained only from classical documentary evidence (such as chronicles, annals, letters etc.). Significantly lower numbers of events were recorded in the 1940s and in the 1950s. In the first case it was connected with the period of World War II with priority of other type of reports than about weather extremes. In the second case it was related to the period of political fanaticism after the onset of Communism in the former Czechoslovakia. Reports, about weather disasters, did not fit to official ideology that the "new man" will manage nature and its processes (Dobrovolný and Brázdil, 2003; Brázdil et al., in press). Other similarly analysed European series are shorter and related to documentary data and systematic (instrumental) observations at one particular 

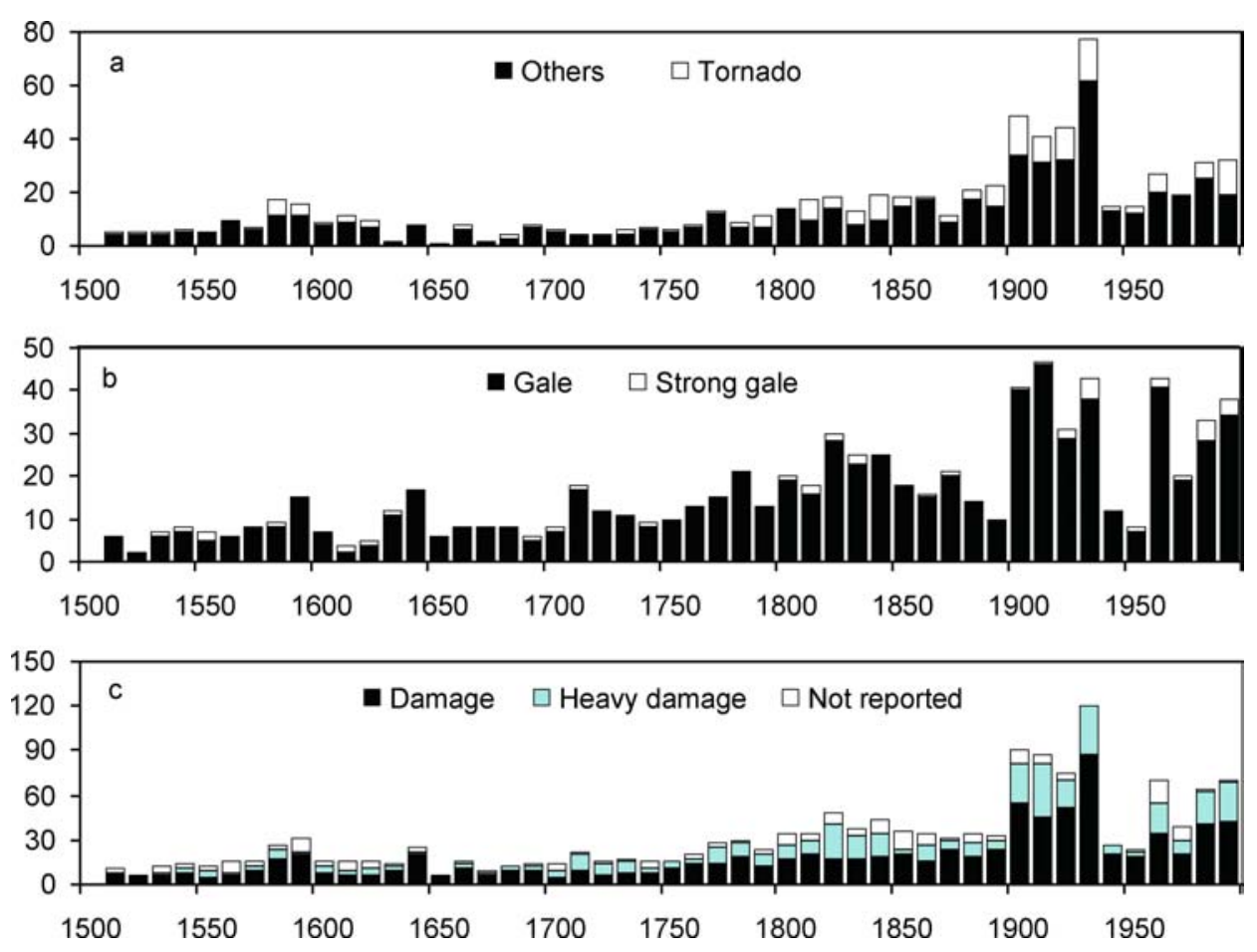

Figure 9. Fluctuations in decadal frequencies of the occurrence of strong winds (based on documentary evidence) connected with convective storms (tornadoes and others) (a), gales (b) and case of strong winds with damage (c) in the Czech Republic over the period AD 1500-1999 (Brázdil et al., in press). Years indicate the first year of the respective decade.

place (e.g. Dawson et al., 1997; Schiesser et al., 1997; Sweeney, 2000; Hickey, 2003).

Many scientific investigations that focus on the causes, the seasonality and the intensity of climatic anomalies and extremes do not consider the societal consequences, while other studies address both questions simultaneously. Only a certain part of climatic anomalies and extremes, however, generates damage. For instance, according to Brázdil et al. (1998), in the years 1957-1995, all the material damage and the loss of lives related to weather extremes in southern Moravia (the Czech Republic) was due to only about $6 \%$ of all thunderstorms and about $23 \%$ of all hailstorms. This knowledge corresponds to similar results by Changnon (1997) for the USA where only $5-10 \%$ of all thunderstorms and $10-25 \%$ of all hail produce damage. Systematic records of the impact of extremes are useful for the compilation of their chronologies. De Kraker $(1999,2002)$ utilised data from accounts of dikes protecting a polder region in northern Flanders to trace the occurrence of high tides, storms and storm surges in the past millennium. The magnitude of impacts is, to a considerable extent, a result of the interaction between physical parameters and the vulnerability of societies; the latter involves the awareness and the preparedness 
for such events (e.g., in the adaptation of land use and the setting up of a warning system), which fluctuates in both space and time. Systematic time series of the material and immaterial damages were only recently established for the 19th and 20th century Switzerland (Pfister, 2002), though such data could also be obtained for other countries using documentary sources such as chronicles, newspapers and - for the last decades - the records of insurance companies, if these have survived.

Floods and storms are counted among the most devastating natural disasters, as in Central Europe the examples of the "millennium flood" in July 1342 (Bork et al., 1998; Tetzlaff et al., 2001) and of the recent catastrophic flood in August 2002 demonstrated (Kachelmann, 2002; Mudelsee et al., 2003). Records of major historical floods were included into compilations of flood reports already quite long ago (e.g., see Pötzsch, 1784; Weikinn, 1958-2002; Jones et al., 1984). This evidence, however, was not systematically analysed from a scientific point of view until recently. Flood series as well as individual severe flood events in the pre-instrumental period in Europe have been subject to several recent studies (e.g., see Pfister and Hächler, 1991; Camuffo and Enzi, 1996; Krahe, 1997; Brázdil, 1998; Glaser, 1998; Deutsch et al., 2000; Schmidt, 2000; Tol and Langen, 2000; Williams and Archer, 2000; Munzar, 2001; Deutsch and Pörtge, 2002). For instance, Barriendos and Martín-Vide (1998) investigated flood magnitude and frequency within the context of climatic variability for the last centuries for central Spain and Catalonia. The authors report on the importance of documentary data to illustrate the high sensitivity of flood magnitude and frequency to the climatic variability. They found periods with high flood frequency over the last centuries with similar seasonal distribution compared to present conditions. Brázdil et al. (1999) analysed in detail the severity and frequency of floods during the 16th century in different European drainage areas. They found a prevalence of flood occurrence during the second half of the 16th century for Central European and Andalusian rivers, while Italian and Catalonian rivers had a higher occurrence of floods during the first half of the same century. Heavy Rhine floods in Basle (Switzerland) appeared on average each 9.5 years since 1496 up to 1882 while in the following 112 years the average return period lengthened to 18.7 years. No truly extreme flood event was observed between 1882 and 1994 (Pfister, 1999). Benito et al. (2003) analysed not only the frequency of flooding in the Tagus basin (central Spain) over the last millennium, but based on water-level marks and other documentary evidence and using a hydraulic model, they also estimated the peak discharges of floods. They concluded that flood magnitude and frequency is highly sensitive to the climatic variability. Llasat et al. (2003) investigated the flash flood of June 2000 in Catalonia and compared it with the floods that have occurred since the 14th century. They concluded, that comparable catastrophic events have been recorded at least once each century and that they are associated with similar meteorological situations. Mudelsee et al. (2003) studied long records of winter and summer floods of the Elbe and Oder rivers. They found a decrease in winter flood occurring in both rivers for the past 80 to 150 years, while summer floods show no trend. Additionally, the authors 


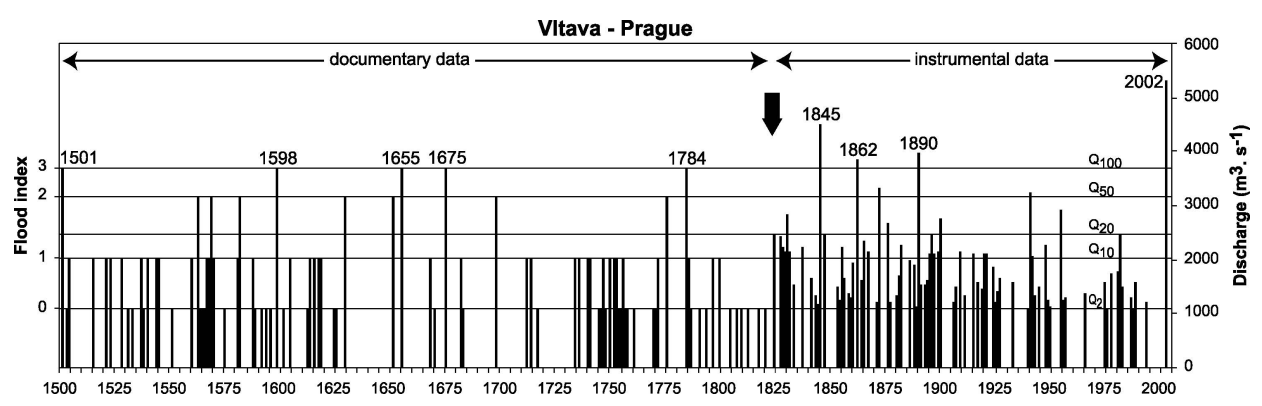

Figure 10. Chronology of floods on the Vltava at Prague in AD 1500-2002 - a synthesis of documentary evidence and instrumental records. Left: floods according to documentary data interpreted in the scale 0-3 (for explanation see Sturm et al., 2001). Right: measured peak discharges during floods with $n$-year water levels; for instance, $Q_{20}$ corresponds to the peak discharge rate with return period of 20 years.

detected significant long-term changes in flood occurrence rates in the 16th-19th centuries.

Following a series of severe flood events in Europe since the 1990s (e.g., in the Rhine and the Meuse area in December 1993 and January 1995, the Oder and the Morava area in July 1997, the Vltava and the Elbe in August 2002) a SwissGerman-Czech research project named FLOODRISK was initiated to investigate the frequency of severe floods in Central Europe back to AD 1500 on the basis of documentary data (Wanner et al., 2004). A particular focus was set on the study of natural variability because the question is regularly asked as to whether such events in recent times are just an expression of natural climate variability or rather a result of recent global warming (Weichselgartner, 2000; Sturm et al., 2001; Hesselink, 2002).

Figure 10 represents the chronology of floods with peak discharge rates $\geq 1090 \mathrm{~m}^{3} \cdot \mathrm{s}^{1}$ (this peak discharge rate corresponds to the return period of 2 years, further denoted as "2-year water") in the Vltava at Prague during AD 1500-2002. Regular measurements started there in 1825. Floods before 1825 were derived from documentary evidence. The flood of August 2002 due to continuous precipitation during three days, with 17 victims and material damage around 75 billion Czech crowns (around 1/10 of the national budget value), was estimated to be a "500-year water" $\left(5160 \mathrm{~m}^{3} \cdot \mathrm{s}^{1}\right)$. It has only one known analogue, the case from July 1432 which was known as "a flood of millennium" in Bohemia. Between this flood and the event in the year 2002, the February flood of 1784 due to ice movement was taken to be the highest with a calculated peak discharge rate, according to watermarks of $4580 \mathrm{~m}^{3} \cdot \mathrm{s}^{1}$. Flood intensity indices (on a scale from 0 to 3 ) from the pre-instrumental period, based on documentary evidence (Sturm et al., 2001), are also shown in Figure 10. This figure shows two long periods with no severe floods, namely between 1675 and 1784 and 1890 and 2002. On the other hand, the second part of the 16th century and most of the 19th century belonged to the most severe flood periods. During 1630-1730 the recorded number of floods with lower index might be influenced by some gaps in the documentary evidence. There is a necessity 
to take in consideration natural and anthropogenic changes in the catchment area during some centuries (e.g. land-use) as well as the fact that extreme floods can significantly alter the character and the course of a river.

The historical flood series clearly suggests decadal scale variability. But the data set itself does not clearly answer the question of whether this time series is representing a purely stochastic process. In recent years, the first attempts have been undertaken to study the relation between the flood frequency and atmospheric circulation changes (e.g., Hirschboeck, 1987; Jacobeit et al., 2003; Wanner et al., 2004). In general, it can be stated that flooding catastrophies in larger areas appear to develop in preferred locations and can be linked to anomalous atmospheric circulation patterns. These patterns persist over a longer period of days and weeks and lead to a strengthened humidity transport from the oceans to the continents.

It is still a topic of intense research to find the mechanisms that link the process of warming at the global level and other large scale forcing factors with features such as severe anomalies and hazards at the regional level. This has yet to be done, because the public opinion is very sensitive to extremes which occur near or within the region where they live. Last, but not least, it is controversial regarding how far natural hazards are purely natural and how far they are aggravated by human activity (e.g. Weichselgartner, 2000; Houghton et al., 2001; Hesselink, 2002; Mudelsee et al., 2003).

\subsection{CLIMATIC IMPACTS AND THE VULNERABILITY OF PAST ECONOMIES AND SOCIETIES}

Whereas the study of future climatic impacts on humankind has developed into a well-funded avenue of research, the climatic vulnerability of past societies has only found a limited attention. To some extent this is connected to the long tradition of climatic determinism which postulated that climate has been one of the most powerful factors in determining the course of human history (e.g. Huntington, 1907, 1925; Markham, 1947; Claiborne, 1970). Particularly crude and unscientific examples of this position were recently provided by Beck (1993) and Hsü (2000).

From the early 20th century social scientists such as Emile Durkheim vigorously reacted against this school of thought by framing the axiom that social issues could solely be explained by social factors (Glaeser, 1994). Durkheim's axiom is still believed by many social scientists today, and this is one of the obstacles to interdisciplinary co-operation between natural and social sciences. A more adequate position, avoiding both extremes of rejecting any role of the natural environment and of assigning it a dominant role, was formulated by the German geographer Wilhelm Lauer (1981): "Climate shapes the theatre in which human existence - the history of the human race - takes place, sets borders for that which can happen on the earth, but certainly does not determine what happens or will happen. Climate introduces problems that man has to solve. Whether he solves them, or how he solves them, is 
left to his fantasy, his will, and his formative activities. Or, expressed in a metaphor: climate does not compose the text for the development drama of mankind, it does not write the movie script, that man does alone."

Another point was the lack of continuous, homogeneous and quantitative highresolution evidence of temperature and precipitation needed for the building of appropriate models. Finally, the use of blanket terms such as the MWP and LIA in comparisons of climatic conditions with developments in human history and society was not very helpful, because it overshadowed the complexity of the task and lead to hasty conclusions. The topic of climatic change was investigated again after World War II by members of the French Annales School such as Fernand Braudel and Emmanuel Le Roy Ladurie. In the well-known "History of Climate" Le Roy Ladurie (1967) pointed out that: "In the long term the human consequences of climate seem to be slight, perhaps negligible, and certainly difficult to detect." Wigley et al. (1985) provided a basic study concerning historical climate impact assessments.

The issue of whether climatic change had a significant impact on "history" is controversial (Brown, 2001). However, it should not be overlooked that both "climate" and "history" are blanket terms located on such a high level of abstraction that relationships between them cannot be investigated according to the rules of scientific methodology. In order to become more meaningful, the issue needs to be broken down to lower scales of analysis, e.g. by putting a focus on specific human activities and/or needs in relation to a given set of climatic variables. For the needs of pre-industrial societies, it primarily concerns the availability of biomass (e.g. food, fodder) and energy (e.g. wind, water-power, draught animals), followed by the processes of population dynamics (e.g. patterns of diseases and epizootics, as well as fertility of men and live-stock), and transport and communications as well as military and naval operations. Undoubtedly, beneficial climatic effects tend to enlarge the scope of human action, whereas climatic shocks restrict it or, in the worst case lead to emergency situations. The impact of sequences of climatic events on energy availability and population dynamics depends on the environmental, cultural and historical context (Pfister, 2001).

Models of climatic effects on society are often framed as a chain of causation (Kates, 1985). Climatic patterns have a first order or biophysical impact on agricultural production or on the outbreak of diseases or epizootics (e.g. Pfister, 1984). These may have second-order effects on prices of food or raw materials which may then ramify into the wider economy and society (third-order impacts). In the late 19th century, economists and geographers such as Stanley Jevons and Eduard Brückner were looking for climatic cycles, because climate was still an important determinant of food prices (Stehr and von Storch, 2000a). The concept of "Little Ice Age Type-Impacts" (LIATIMP) was recently proposed by Pfister (in press). LIATIMP also stands for a numerical model that simulates biophysical impacts on agriculture based on climatic data and comprise cold and rainy mild-summers, chilly springs and rainy autumns. Prior to the mid-20th century such situations 
affected all agricultural resources at the same time (for 17th century Saxony, see Militzer, 1996, 1998). It was demonstrated that the level of LIATIMP was significantly higher during the period 1568-1630 than during the previous and subsequent decades.

Baten (2002) studied human stature as an indicator for nutritional status. He argued that European climate in the 18th century significantly influenced nutritional status as measured with anthropometric indices on a quinquennial or decadal basis. According to him there was a causal chain leading from warmer (colder) winters to higher (lower) grain and protein production, and these factors determined real wages and finally human stature.

Bauernfeind (1993) looked into grain price formation on the Nuremberg market (southern Germany) from AD 1339 to 1670. After having controlled prices for currency devaluation he concluded that long-term trends of grain prices were primarily caused by both the growth and decline of population and climate variations. Bauernfeind and Woitek (1999) analysed quantitatively the impact of seasonal temperature and precipitation on the price fluctuations of several commodities, including rye, butter and honey, at Nuremberg, Cologne, Augsburg and Munich (Germany) during the period 1490-1620. It turned out that in the last third of the 16th century climatic changes became the most significant factor affecting food prices.

Brázdil and Durdáková (2000) studied series of prices for rye, wheat, barley and oats for Brno, Dačice and Olomouc (the Czech Republic) for the 16th-18th centuries. A focus was put on 61 years of crisis, in which prices stood at a very high level. According to the authors the relation to a poor harvest and to adverse weather in the given or in the preceding year was obvious in $67 \%$ of the crisis years. This result points to the fact that climate is only one, albeit an important factor affecting subsistence levels in agrarian societies.

Wine was another important source of income for institutions and for the landed gentry on the basis of tithes, taxes or sharecropping. In Central Europe viticulture is at its northern limit and therefore the growth, yield and sugar content of grapes are very dependent on climate. Landsteiner (1999) compared wine production in four areas north of the Alps - the Zurich area, Württemberg, Lower Austria and western Hungary - over the period 1550-1630. In all regions wine production slumped from the 1580s initiating a long series of consecutive crop failures continuing until the late 1590 s or the early 1600s. This calamity is attributed to a 15 -year downturn of summer temperatures north of the Alps (Pfister and Brázdil, 1999). In lower Austria the collapse of wine production and hence high prices, led the public to switch from wine to beer consumption. The Hapsburg Emperor, who drew a substantial part of his income from wine production, had to double the heavy export duty on wine in order to be able to meet the interests on the state debt. Moreover harvest failures put a severe strain on the budgets of urban wine producers, and deficient grain harvests reduced the real wages of the vinedressers by $50 \%$ (Landsteiner, 1999).

The farther we move away from first-order impacts, the greater is the complexity of the factors masking the climatic effect. It is easier to investigate the 
effects of short-term (annual and interannual) impacts. In dealing with the effects of multidecadal climate variations we have to account for modifications in the economic, institutional and environmental setting so extensively as to vitiate any attempt at strict comparison or measurement. Most climatic impacts were related to food scarcity or famines. In most cases, impacted societies had developed adaptive and adjustive mechanisms to buffer climatic shocks and to avoid risk by growing different kinds of crops (e.g. Barriendos and Dannecker, 1999). Moreover, parameters such as social stratification and governance need to be considered. This is illustrated by Brázdil et al. (2001) who investigated the consequences of the wellknown European subsistence crises in 1770-1771 for the Czech Lands. A long wet spell in mid-summer together with other weather, economic and social factors, caused a dramatic surge in grain prices leading to dearth, diseases and extremely high population mortality (Figure 11). Although the Imperial Court in Vienna took measures for relief, one tenth of the population died in Bohemia during those years. The dearth lead to a change in the diet of the poor strata of society, and this became one of the triggers for the subsequent uprising of serfs in 1775 .

In other parts of central Europe the demographic consequences of this climatic impact were less dramatic, because the social buffers were adequate. This is demonstrated from the example of the Swiss Canton of Bern, where the level of mortality did not rise despite the adverse weather (Pfister, 1978), because the system of local and regional poor-relief was well developed. However, the level of community taxes rose sharply as a consequence (Flückiger-Strebel, 2002). The comparison of these two examples, the Czech Lands and the Canton of Bern highlights the social dimension of food poverty, which may be aggravated or alleviated by the

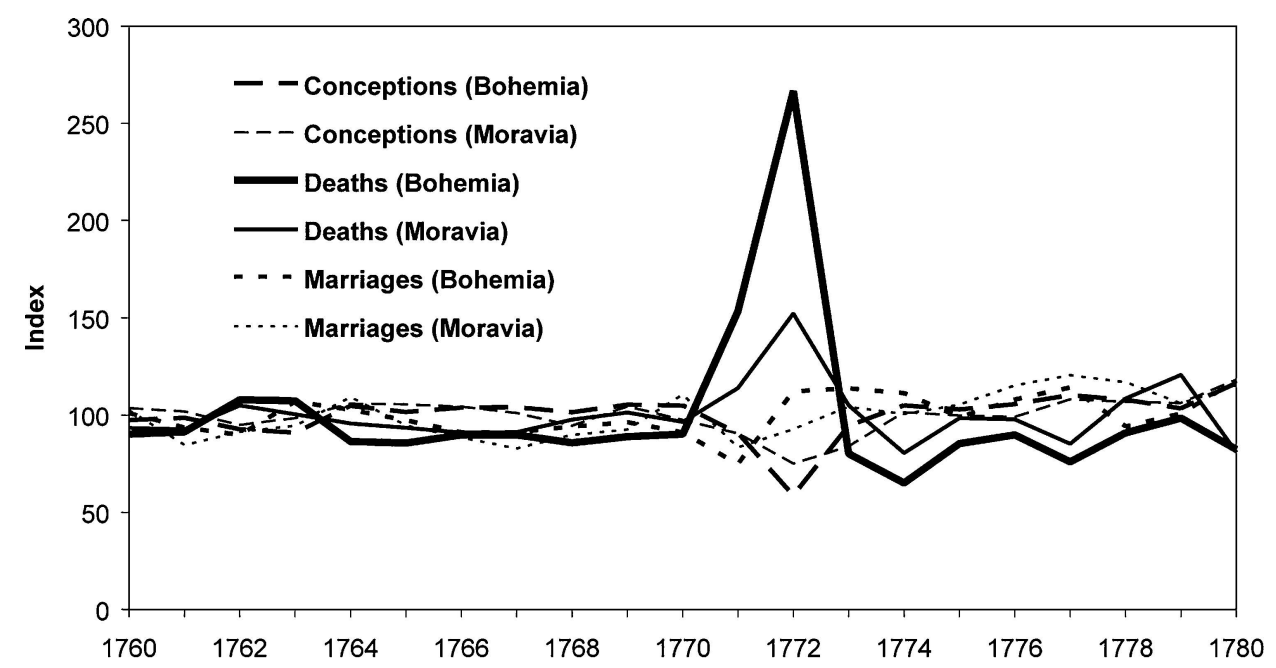

Figure 11. Fluctuations in indices of conceptions, deaths and marriages in Bohemia and Moravia (the Czech Republic) in the period 1760-1780 (100 is average of 1760-1780) (Brázdil et al., 2001). 
management of the crisis by the authorities (Newman, 1990). More regional examples are needed in order to get a coherent view on the many dimensions that are related to this issue.

When studying the effect of climatic variations on past societies, little can be learned from the management of recent or ongoing climate variations, simply since the societal conditions, in terms of organisation, technology and demography have changed. The impact of climate variations and extremes is non-stationary. However, the way people think about climate, how they perceive extremes, is changing much less. Therefore, the aspect of "images and social representation" discussed in the next section is of great practical importance for the ongoing discourse about anthropogenic climate change and how people, nations and societies will deal with the threat of global warming.

\subsection{IMAGES AND SOCIAL REPRESENTATIONS OF CLIMATIC ANOMALIES AND NATURAL DISASTERS}

A cultural history of environmental affairs stresses the point that a certain attitude to nature depends on a particular world-view or view on nature that is changeable with time (Glacken, 1967). If we understand culture as the construction of reality, then weather, climate and natural disasters become a part of the cultural history of mankind (Kempe, 2003). This kind of research is still in its infancy (e.g., Rebetez Beniston, 1992; Rebetez, 1996; Coates, 1998; Fleming, 1998; Favier and GranetAbisset, 2000; Jankovic, 2000; Coeur, 2003; Groh et al., 2003; Jakubowski-Tiessen and Lehmann, 2003; Kempe and Rohr, 2003; Stuber, 2003). Historical climatology is called to participate in investigating the ideas and images and social representations of climatic anomalies and natural disasters. It is a multidisciplinary field that involves also cultural historians, historians of religion and mentality and linguists. The contribution of historical climatology might be twofold: On the one hand, historical climatologists are familiar with the sources in which historical perceptions of weather are found, where quasi "objective" observations and superstitious interpretations of anomalies can be part of the same records. On the other hand, historical climatologists have produced high-resolution quantitative reconstructions of weather and climate. This kind of statistical product derived from the original evidence may be needed to rectify views, which cast doubt on the reality of the extreme phenomena that are described in the records.

Behringer (1999), who investigated the connections between witchcraft and climate in Europe, is a good example for dealing with climate and social representation. Although in popular imagination witchcraft has traditionally been seen as one of the major causes for hailstorms, Christian ecclesiastical authorities in the Early and High Middle Ages refused to accept such accusations. It was only in the 1380s that magic and weather-making became increasingly prominent in inquisitorial trials. During the 1480s the Church finally accepted the image of the weather-making 
witch. This was mainly the work of the Alsatian Dominican friar Heinrich Kramer, who summarised these ideas in his notorious Malleus maleficarum, The Witches' Hammer, published in 1486.

Harsh criticism by humanists at the beginning Reformation temporarily stopped inquisitorial witchcraft persecution in the early 16th century. The debate was resumed in the 1560s and accompanied by a debate on weather-making because this was the most important charge against suspected witches. Though witches were certainly made responsible for all kinds of bad luck, weather is especially important in an agrarian society. Crop failure caused increases in prices, malnutrition, rising infant mortality and, finally, epidemics. Starting in the 1560s, a series of witch panics shook European societies and were followed by attempts to legalise witchcraft persecutions. From the 1580 s to the end of the 1620 s, persecution increased to a previously unknown extent, when thousands of persons were burnt in many parts of Western and Central Europe. This period coincides with the decade long downturn in climate that leads to a long-term deterioration of the living conditions of the majority of the people. New research demonstrates that the persecution was indeed not only demanded but also organised by the population. Accusations and persecutions were synchronous in far-away countries, not connected by dynastic, confessional, economic or other links. This demonstrates the importance of the climatic factor as a contributing explanation (Behringer, 1999). It seems that climatic change and variability is becoming a significant topic in the history of mentalities.

Another example is the lengthy list of cases when Europeans and North Americans believed to be subject to man-made climate change (von Storch and Stehr, 2000, 2002). This list includes the witches just mentioned, but also the concern about newly installed lightning rods, redirection of ocean currents, nuclear explosions, deforestation and many more. Von Storch and Stehr $(2000,2002)$ claim that the concept of adverse anthropogenic climate change is an integral part of the Western culture, so that relating weather extremes to anthropogenic causes is easily accepted as plausible.

\subsection{POTENTIAL OF HISTORICAL CLIMATOLOGY FOR CLIMATE MODELLING}

Recently, the first attempts were made to reconstruct climate variations during the last few hundred years using dynamic climate models forced with reconstructed time series of forcings. One such study was conducted by Fischer-Bruns et al. (2002). With the state-of-the-art climate model ECHO-G, the effect of time varying solar and volcanic-aerosol forcing has been simulated. This model is composed of the atmospheric GCM ECHAM4 with T-30 resolution and an oceanic circulation model HOPE-G with T-42 resolution (for more details, see Zorita et al., in press). During the winters $1675-1710$ a marked global cooling was simulated. This event mimics, in terms of broad patterns and time mean intensity, the strong cooling "Late Maunder Minimum" (LMM, 1675-1710) period in Europe documented in various historical 

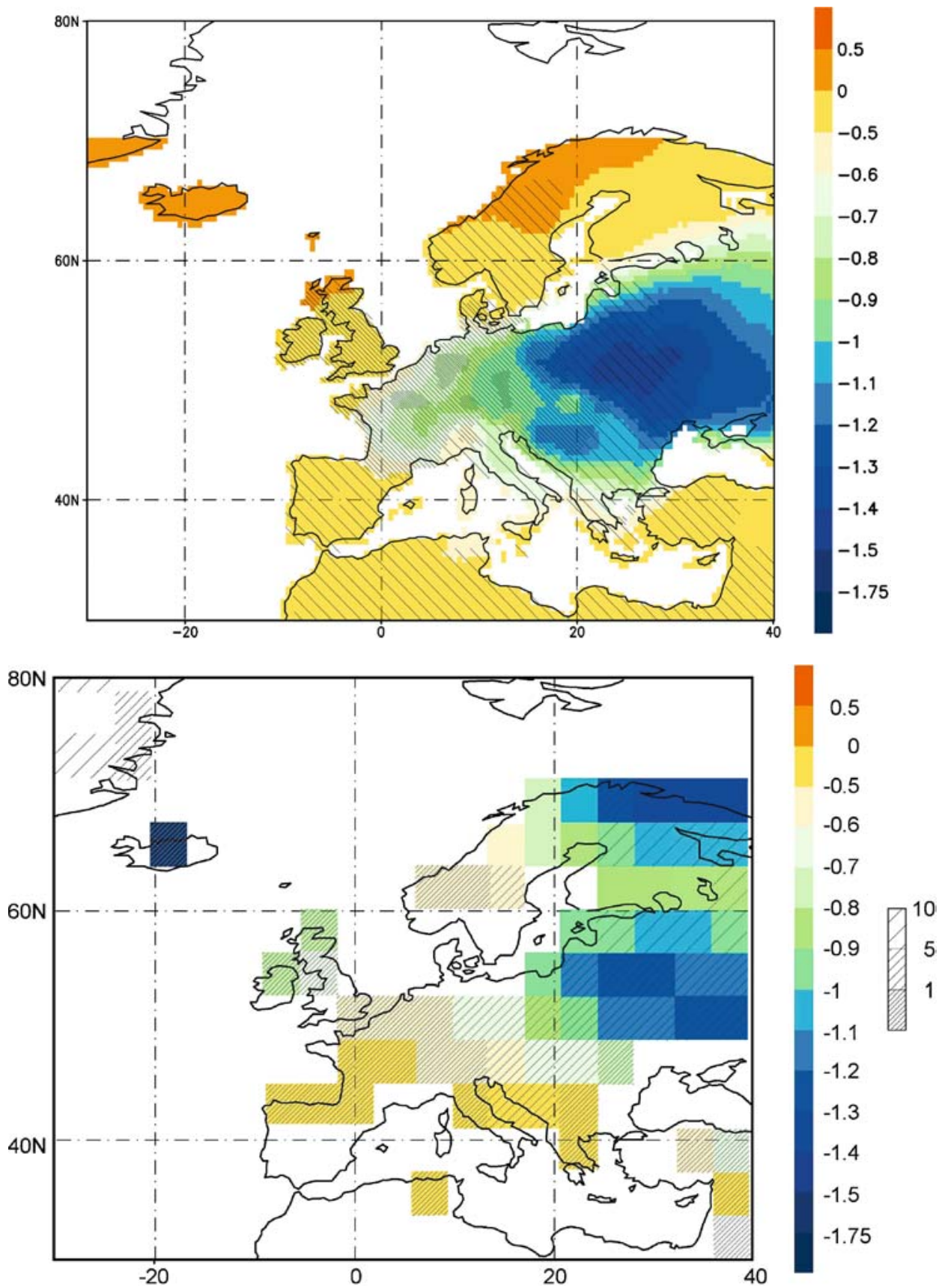

Figure 12. Representation of the winter temperature deviation during the Late Maunder Minimum, 1675-1710 vs. 1550-1800, according to historical reconstructions (top; Luterbacher et al., 2004) and a simulation with the climate models ECHO-G (bottom; von Storch, (c) Springer-Verlag 2004). The hatching in the top diagram represents the proportion of described variance $(>40,70$ and $90 \%)$ and in the bottom diagram the risk for rejection the null hypothesis of no change (10, 5 and $1 \%)$. 
sources and early instrumental time series. Figure 12 shows the mean temperature change (1675-1710 minus 1550-1800) in Europe as reconstructed by Luterbacher et al. (2004) from historical evidence and as simulated by the ECHO-G model. The hatching indicates the statistical confidence of the features, i.e., non-hatched features are quite uncertain, whereas dense hatching represents high confidence.

This comparison of a climate reconstruction based on documentary and instrumental data with results from a model run using reconstructed external forcing, serves as an early example of how historical climatology and dynamic climate modelling can supplement each other in our efforts towards improved understanding of past climatic variability and how the climate system responds to external forcings. The LMM modelled by the forced ECHO-G integration (Zorita et al., in press) is causally related to the solar and volcanic forcing anomalies in the preceding decades and during the LMM. The model simulation has the advantage that it provides the climatic state of the whole globe. According to this model, the temperatures were lower everywhere north of about $30^{\circ} \mathrm{S}$ during the LMM than in the earlier and later times, with a marked cooling of the Labrador Sea. In this simulation the cooling in Europe is not simply related to anomalous easterly winds over the region, but to a general more widespread cooling. A survey among a variety of proxy data from ice cores, corals and other data supports this notion of an almost global response (Zinke et al., 2004).

\section{Conclusions}

Historical climatology has made a great deal of progress after 1990, due to an important extension of its research possibilities. Based on the current evaluation of its present state, it is possible to formulate prospects of future investigations in this research field. They can be summarised as follows:

(i) Completion of the existing databases. Cross-referencing and combination of different data for achievement of the most complete reconstruction of past climates.

(ii) Compilation of further series of temperature and precipitation indices for different countries of Europe. Assess average temperature and precipitation indices from these series. Develop average series for major regions of Europe.

(iii) Improvement of the mathematical-statistical tools used for reconstructing temperature and precipitation series from documentary evidence.

(iv) Compilation of time series of weather and climate extremes and natural disasters. Evaluation in terms of severity, seasonality, causes, impacts and evolution over time.

(v) Improvement of statistical tools for estimating past circulation patterns and spatial representation of temperature and precipitation conditions. 
(vi) Closer co-operation with climate modellers and use of GCM outputs to study climate forcing and to augment attempts to reconstruct past climate states by skilfully combining empirical evidence and dynamical knowledge encoded in dynamical climate models (with avoiding circularity).

(vii) Co-operation with economists, historians, anthropologists, sociologists and archaeologists in order to investigate the impact of past climate fluctuations and extremes upon the economy, human health and well-being, and to understand the social mechanisms to adapt to climate change and extremes.

(viii) Investigations into images and social representations of past weather, climate and climatic extremes in co-operation with psychologists, historians and anthropologists. Comparison of the imagined climate with the "real" climate reconstructed from different kinds of evidence.

Historical climatology is not only an academically attractive activity; it is of utmost importance for the contemporary discussion about ongoing anthropogenic climate change. It is providing information about the range of "natural variations" of a climate very close to the present one. After successful reconstructions of the climate of the 20th century have been completed (Houghton et al., 2001), joint efforts to reconstruct the climate of the 19th and 18th century should be pursued. Such reconstructions would provide a considerably improved basis for the problem of detecting and attributing ongoing climate change. By documenting the responses of past societes to perceptions and realities of climate change, useful strategies may be discovered for improving the ability of present day innovative networks to deal with this issue (Sarewitz and Pielke, 2000).

There is a hope that historical climatology will further develop not only in Europe and eastern Asia (such as China, Japan, Korea), where there exist great scientific and data potentials, in particular as regards documentary data, but also in other parts of the world, such as Latin America (Metcalfe et al., 2002) and potentially the Islamic World.

\section{Acknowledgements}

The authors would like to thank:

- the Grant Agency of the Czech Republic for giving financial support with Grant No. 205/01/1067;

- the Swiss National Science Foundation through the Swiss National Competence Center for Research on Climate (NCCR), project PALVAREX;

- two anonymous reviewers and Anders Moberg (Stockholm) for a meticulous reading of the text, suggesting further style corrections and raising critical questions;

- Dario Camuffo (Padua), for recommendation of some Mediterranean references, Paul Della-Marta (Bern) for English style corrections, Pavla 
Štěpánková, Jarmila Macková and Radek Neužil (Brno) for technical help with some figures.

\section{References}

Alcoforado, M.-J., de F. Nunes, M., Garcia J. C., and Taborda, J. P.: 2000, 'Temperature and precipitation reconstruction in southern Portugal during the Late Maunder Minimum (AD 1675-1715)', Holocene 10, 333-340.

Alexandre, P.: 1987, Le climat en Europe au Moyen Age. Contribution à l'historie des variations climatiques de 1000 à 1425, d'après les sources narratives de l'Europe occidentale, École des Hautes Études en Sciences Sociales, Paris, 825 pp.

Amberg, B.: 1890, Beiträge zur Chronik der Witterung und verwandter Naturerscheinungen mit besonderer Rücksicht auf das Gebiet der Reuss und der angrenzenden Gebiete der Aare und des Rheines, Jahresber. Höh. Lehranst. Luzern, 86 pp.

Angot, A.: 1885, 'Etude sur les Vendanges en France', Annales du Bureau Central Météorologique de France, publiées par E. Mascart. Année 1883. I. Étude des orages en France et Mémoires divers. Paris, B.29-B.120 (sic!).

Angot, A.: 1895, Première catalogue des observations météorologiques faites en France depuis l'origine jusqu'en 1850, Annales du Bureau Central Métérologique de France, Paris.

Appleby, A. B.: 1981, 'Epidemics and Famine in the Little Ice Age', in Rotberg, R. I., and Rabb, T. K. (eds.), Climate and History. Studies in Interdisciplinary History, Princeton University Press, Princeton, New Jersey, pp. 63-83.

Bachmann, H.: 1984, Kalenderarithmetik, Juris, Zürich, 104 pp.

Baker, A., Proctor, C. J., and Barnes, W. L.: 2002, 'Stalagmite lamina doublets: A 1,000 year record of severe winters in NW Scotland?', Int. J. Climatol. 22, 1339-1345.

Balandin, R. K.: 1975, Puls zemnikh stichiy, Mysl, Moskva, 206 pp. German translation: Naturkatastrophen. Der Pulsschlag der Naturgewalten. Teubner, Leipzig 1988.

Barash, S. I.: 1989, Istoriya neurozhayev i pogody v Evrope (po XVI v. n. e.), Gidrometeoizdat, Leningrad, $238 \mathrm{pp}$.

Barriendos, M.: 1997, 'Climatic variations in the Iberian Peninsula during the late Maunder Minimum (AD 1675-1715): An analysis of data from rogation ceremonies', Holocene 7, 105-111.

Barriendos, M. and Dannecker, A.: 1999, 'La sequia de 1812-1824 en la costa central catalana. Consideraciones climaticas e impacto social del evento', in Nadal, R., José, M. and Martín-Vide, J. (eds.), La climatologia espanola en los albores del siglo XXI, Villassar de Mar, pp. 53-62.

Barriendos, M. and Martín-Vide, J.: 1998, 'Secular climate oscillations as indicated by catastrophic floods in the Spanish Mediterranean coastal area (14th-19th centuries)', Clim. Change 38, 473491.

Baten, J.: 2002, 'Human stature and climate: The impact of past climate on living standards', in Wefer, G., Berger, W. H., Behre, K.-E., and Jansen, E. (eds.), Climate Development and History in the North Atlantic Realm, Springer-Verlag, Berlin, Heidelberg, New York, Barcelona, Hong Kong, London, Milan, Paris, Tokyo, pp. 327-338.

Bauer, E., Claussen, M., Brovkin, V., and Huenerbein, A.: 2003, 'Assessing climate forcings of the Earth system for the past millennium', Geophys. Res. Lett. 30, 1276-1279.

Bauernfeind, W.: 1993, Materielle Grundstrukturen im Spätmittelalter und der Frühen Neuzeit, Preisentwicklung und Agrarkonjunktur am Nürnberger Getreidemarkt von 1339 bis 1670, Universitätsbund Erlangen-Nürnberg, $320 \mathrm{pp}$.

Bauernfeind, W. and Woitek, U.: 1999, 'The influence of climatic change on price fluctuations in Germany during the 16th century price revolution', Clim. Change 43, 303-321. 
Beck, R. A.: 1993, 'Viewpoint: Climate, liberalism and intolerance', Weather 48, 63-64.

Behringer, W.: 1999, 'Climatic change and witch-hunting: The impact of the Little Ice Age on mentalities', Clim. Change 43, 335-351.

Behringer, W., Lehmann, H., and Pfister, C. (eds.): in press, Kulturelle Konsequenzen der Kleinen Eiszeit - Cultural Consequences of the Little Ice Age, Vandenhoek \& Ruprecht, Göttingen.

Bell, W. T. and Ogilvie, A. E. J.: 1978, 'Weather compilations as a source of data for the reconstruction of European climate during the medieval period', Clim. Change 1, 331-348.

Benito, G., Diéz-Herrero, A., and Fernández de Villalta, M.: 2003, 'Magnitude and frequency of flooding in the Tagus basin (Central Spain) over the last millennium', Clim. Change 58, 171192.

Bergström, H. and Moberg, A.: 2002, 'Daily air temperature and pressure series for Uppsala (17221998)', Clim. Change 53, 213-252.

Bernhardt, K. and Mäder, C.: 1987, 'Statistische Auswertung von Berichten über bemerkenswerte Witterungsereignisse seit dem Jahre 1000', Z. Meteorol. 37, 120-130.

Bokwa, A., Limanówka, D., and Wibig, J.: 2001, 'Pre-instrumental weather observations in Poland in the 16th and 17th centuries', in Jones, P. D., Ogilvie, A. E. J., Davies, T. D., and Briffa, K. R. (eds.), History and Climate: Memories of the Future?, Kluwer Academic/Plenum Publishers, New York, Boston, Dordrecht, London, Moscow, pp. 9-27.

Bonardi, L.: 1996, 'Elementi per una storia del clima nella montagna lombarda centro-orientale', Rivista Geografica Italiana 103, 405-430.

Bonardi, L.: 2000, 'Le cause climatiche del Maximum Glaciale del periodo 1815-1820 nelle Alpi Lombarde: un ipotesi qualitativa', Terra glacialis 3, 9-22.

Borisenkov, Ye. P.: 1992, 'Documentary evidence from the U.S.S.R.', in Bradley, R. S. and Jones, P. D. (eds.), Climate Since A.D. 1500, Routledge, London and New York, pp. 171-183.

Borisenkov, Ye. P. and Pasetskiy, V. M.: 1988, Tysyatcheletnaya letopis neobytchaynykh yavleniy prirody, Mysl, Moskva, $524 \mathrm{pp}$.

Bork, H. R., Bork, H., Dalchow, C., Faust, B., Piorr, H.-P., and Schatz, T.: 1998, Landschaftsentwicklung in Mitteleuropa. Wirkungen des Menschen auf Landschaften, Klett-Perthes, Gotha, Stuttgart, $328 \mathrm{pp}$.

Börngen, M. and Tetzlaff, G.: 2000, 'The weather report during 1652-1659 of Mauritius Knauer at Langheim (NE Bavaria, Germany) as a source of quantitative data', Meteorol. Zeitschrift 9 , 308-317.

Bradley, R. S.: 1996, 'Are there optimum sites for global paleotemperature reconstruction?', in Jones, P. D., Bradley, R. S., and Jouzel, J. (eds.), Climatic Variations and Forcing Mechanisms of the Last 2000 Years, Springer-Verlag, Berlin, Heidelberg, New York, pp. 603-624.

Bradley, R. S.: 1999, Paleoclimatology. Reconstructing Climates of the Quaternary, Academic Press, San Diego, London, Boston, New York, Sydney, Tokyo, Toronto, 610 pp.

Bradley, R. S.: 2000, 'Climate paradigms for the last millennium', PAGES Newsletter 8, 2-3.

Bradley, R. S., Briffa, K. R., Cole, J. E., Hughes, M. K., and Osborn, T. J.: 2003, 'The climate of the last millennium', in Alverson, K., Bradley, R. S., and Pedersen, T. F. (eds.), Paleoclimate, Global Change and the Future, Springer Verlag, Berlin, Heidelberg, New York, pp. 105-141.

Bradley, R. S., Hughes, M. K., and Diaz, H. F.: 2003, 'Climate in medieval time', Science 302, 404-405.

Bradley, R. S. and Jones, P. D. (eds.): 1992, Climate Since A.D. 1500, Routledge, London and New York, 679 pp.

Bradley, R. S. and Jones, P. D.: 1993, 'Little Ice Age' summer temperature variations: their nature and relevance to recent global warming trends', Holocene 3, 387-396.

Brázdil, R.: 1996, 'Reconstructions of past climate from historical sources in the Czech lands', in Jones, P. D., Bradley, R. S., and Jouzel, J. (eds.), Climatic Variations and Forcing Mechanisms of the Last 2000 Years, Springer-Verlag, Berlin, Heidelberg, New York, pp. 409-431. 
Brázdil, R.: 1998, 'The history of floods on the rivers Elbe and Vltava in Bohemia', Erfurter Geogr. Studien 7, 93-108.

Brázdil, R.: 2000, 'Historical climatology: Definition, data, methods, results', Geogr. Čas. 52, 99-121.

Brázdil, R.: 2002, 'Patterns of climate in Central Europe since Viking times', in Wefer, G., Berger, W. H., Behre, K.-E., and Jansen, E. (eds.), Climate Development and History in the North Atlantic Realm, Springer-Verlag, Berlin, Heidelberg, New York, Barcelona, Hong Kong, London, Milan, Paris, Tokyo, pp. 355-368.

Brázdil, R., Dobrovolný, P., Štekl, J., Kotyza, O., Valášek, H., and Jež, J.: in press, History of Weather and Climate in the Czech Lands VI. Strong winds, Masaryk University, Brno.

Brázdil, R. and Durdáková, M.: 2000, 'The effect of weather factors on fluctuations of grain prices in the Czech Lands in the 16th-18th centuries', Prace Geograficzne UJ 108, 19-25.

Brázdil, R., Glaser, R., Pfister, C., Dobrovolný, P., Antoine, J.-M., Barriendos, M., Camuffo, D., Deutsch, M., Enzi, S., Guidoboni, E., Kotyza, O., and Rodrigo, F. S.: 1999, 'Floods events of selected European rivers in the sixteenth century', Clim. Change 43, 239-285.

Brázdil, R. and Kiss, A.: 2001, 'Daily weather observations at Košice, Slovakia, in the period 16771681', Meteorol. Čas. 4, 3-14.

Brázdil, R. and Kotyza, O.: 1995, History of Weather and Climate in the Czech Lands I (Period 1000-1500), Zürcher Geographische Schriften 62, Zürich, 260 pp.

Brázdil, R. and Kotyza, O.: 1996, History of Weather and Climate in the Czech Lands II. The Earliest Daily Observations of the Weather in the Czech Lands, Masaryk University, Brno, $178 \mathrm{pp}$.

Brázdil, R. and Kotyza, O.: 1999, History of Weather and Climate in the Czech Lands III. Daily Weather Records in the Czech Lands in the Sixteenth Century II, Masaryk University, Brno, 228 pp.

Brázdil, R. and Kotyza, O.: 2000, History of Weather and Climate in the Czech Lands IV. Utilisation of Economic Sources for the Study of Climate Fluctuation at Louny and Surroundings in the Fifteenth-Seventeenth Centuries, Masaryk University, Brno, 350 pp.

Brázdil, R., Štěpánek, P., and Vais, T.: 1998, 'Časová a prostorová analýza bouřek, krupobití a extrémních srážek v jižní části Moravy v období 1946-1995', Meteorol. Zpr. 51, 45-52.

Brázdil, R., Štěpánková, P., Kyncl, T., and Kyncl, J.: 2002a, 'Fir tree-ring reconstruction of March-July precipitation in southern Moravia (Czech Republic), 1376-1996', Clim. Res. 20, 223-239.

Brázdil, R. and Valášek, H.: 2002, 'Meteorologická měření a pozorování v Zákupech v letech 17181720', Geografie - Sbor. Čes. Geogr. Spol. 107, 1-22.

Brázdil, R. and Valášek, H.: 2003, 'Use of historic data in studying damage due to natural disasters at the domain of Pernštejn in the period 1694-1718 and as a source of information for the study of meteorological and hydrological extremes', Meteorol. Čas. 6, 3-13.

Brázdil, R., Valášek, H., Luterbacher, J., and Macková, J.: 2001, 'Die Hungerjahre 1770-1772 in den böhmischen Ländern. Verlauf, meteorologische Ursachen und Auswirkungen', Österreichische Zeitschrift für Geschichtswissenschaften 12, 44-78.

Brázdil, R., Valášek, H., and Macková, J.: 2003a, 'Climate in the Czech Lands during the 1780s in light of the daily weather records of parson Karel Bernard Hein of Hodonice (southwestern Moravia): Comparison of documentary and instrumental data', Clim. Change 60, 297-327.

Brázdil, R., Valášek, H., and Sviták, Z.: 2003b, 'Meteorological and hydrological extremes in the Dietrichstein domains of Dolní Kounice and Mikulov between 1650 and 1849 according to official economic records of natural disasters', Geogr. Čas. 55, 325-353.

Brázdil, R., Valášek, H., Sviták, Z., and Macková, J.: 2002b, History of Weather and Climate in the Czech Lands V. Instrumental meteorological measurements in Moravia up to the end of the eighteenth century, Masaryk University, Brno, $250 \mathrm{pp}$.

Briffa, K. R., Jones, P. D., Schweingruber, F. H., and Osborn, T. J.: 1998, 'Influence of volcanic eruptions on Northern Hemisphere summer temperature over the past 600 years', Nature 393, $450-455$. 
Briffa, K. R. and Osborn, T. J.: 2002, 'Blowing hot and cold', Science 295, 2227-2228.

Briffa, K. R., Osborn, T. J., Schweingruber, F. H., Harris, I. C., Jones, P. D., Shiyatov, S. G., and Vaganov, E. A.: 2001, 'Low-frequency temperature variations from a northern tree-ring-density network', J. Geophys. Res. 106, 2929-2941.

Broecker, W. S.: 2001, 'Was the Medieval Warm Period global?', Science 291, 1497-1499.

Brooks, C. E. P.: 1926, Climate Trough the Ages. A Study of the Climatic Factors and Their Variations, Ernest Benn Limited, London, 439 pp.

Brown, N.: 2001, History and Climate Change. A Eurocentric Perspective, Routledge, London and New York, $391 \mathrm{pp}$.

Brönnimann, S.: 2002, 'Picturing climate change', Clim. Res. 22, 87-95.

Brückner, E.: 1890, Klimaschwankungen seit 1700 nebst Bemerkungen über die Klimaschwankungen der Diluvialzeit, Geographische Abhandlungen herausgegeben von Prof. Dr. Albrecht Penck in Wien, E. D. Hölzel, Wien and Olmütz, 325 pp.

Buckland, P. C. and Wagner, P. E.: 2001, 'Is there an insect signal for the "Little Ice Age?"', Clim. Change 48, 137-149.

Buisman, J. and van Engelen, A.: 1995-2000, Duizend Jaar Weer, Wind en Water in de Lage Landen, Franeker, Van Wijnen, vol. 1, to 1300 (1995), 656 pp.; vol. 2, 1300-1450 (1996), 690 pp.; vol. 3, 1450-1575 (1998), 808 pp.; vol. 4, 1575-1675 (2000), 767 pp.

Camuffo, D.: 1987, 'Freezing of the Venetian Lagoon since the 9th century A.D. in comparison to the climate of Western Europe and England', Clim. Change 10, 43-66.

Camuffo, D.: 2002a, 'History of the long series of the air temperature in Padova (1725-today)', Clim. Change 53, 7-75.

Camuffo, D.: 2002b, 'Calibration and instrumental errors in early measurements of air temperature', Clim. Change 53, 297-330.

Camuffo, D.: 2002c, 'Errors in early temperature series arising from changes in style of measuring time, sampling schedule and number of observations', Clim. Change 53, 331-354.

Camuffo, D. and Enzi, S.: 1992, 'Critical analysis of archive sources for historical climatology of Northern Italy', in Frenzel, B., Pfister, C., and Gläser, B. (eds.), European Climate Reconstructed from Documentary Data: Methods and Results, Gustav Fischer Verlag, Stuttgart, Jena, New York, pp. 65-74.

Camuffo, D. and Enzi, S.: 1996, 'The analysis of two bi-millenary series: Tiber and Po river floods', in Jones, P. D., Bradley, R. S., and Jouzel, J. (eds.), Climatic Variations and Forcing Mechanisms of the Last 2000 Years, Springer-Verlag, Berlin, Heidelberg, New York, pp. 433-450.

Camuffo, D. and Jones, P. (eds.): 2002, Improved Understanding of Past Climate Variability from Early Daily European Instrumental Sources, Kluwer Academic Publishers, Dordrecht, Boston, London, $392 \mathrm{pp}$.

Camuffo, D., Secco, C., Brimblecombe, P., and Martin-Vide, J.: 2000, 'Sea storms in the Adriatic Sea and the Western Mediterranean during the last millennium', Clim. Change 46, 209-223.

Cernovodeanu, P. and Binder, P.: 1993, Cavalerii apocalipsului. Calamitatile naturale din trecutul Romaniei (pana la 1800), SILEX - Casa de Editura, Presa si Impresariat S.R.L., Bucuresti, 255 pp.

Changnon, D.: 1997, 'Damaging storms in the United States: Selection of quality data and monitoring indices', in Workshop on Indices and Indicators for Climate Extremes, NCDC, NOAA, Asheville, $24 \mathrm{pp}$.

Chernavskaya, M. M.: 1992, 'Botanical indicators of the Little Ice Age in the Russian Plain', in Mikami, T. (ed.), Proceedings of the International Symposium on the Little Ice Age Climate, Tokyo Metropolitan University, Tokyo, pp. 65-70.

Chernavskaya, M. M.: 1995, 'Klimat yevropeyskoy tchasti Rossii vo vtoroy polovine XVII i pervoy tchetverti XVIII vekov po istoritcheskim dannym', Izvestiya Russkoy Akademii Nauk-Ser. Geogr. 1995, 97-107. 
Claiborne, R.: 1970, Climate, Man, and History, Norton, New York, 444 pp.

Coates, P.: 1998, Nature. Western Attitude Since Ancient Times, Politiy Press, Oxford, 246 pp.

Cocheo, C. and Camuffo, D.: 2002, 'Corrections of systematic errors and data homogenisation in the Padova series (1725-today)', Clim. Change 53, 77-100.

Coeur, D.: 2003, La Maîtrise des Inondations dans la Plaine de Grenoble (XVIIe-XXe Siècle): Enjeux Techniques, Politiques et Urbains. 3 Vols Typoscript. Université Pierre Mendès France, Institut d'Urbanisme de Grenoble, Grenoble, 808 pp.

Cook, E. R., Briffa, K. R., and Jones, P. D.: 1994, 'Spatial regression methods in dendroclimatology: A review and comparison of two techniques', Int. J. Climatol. 14, 379-402.

Cook, E. R., D'Arrigo, R. D., and Mann, M. E.: 2002, 'A well-verified, multiproxy reconstruction of the winter North Atlantic Oscillation Index since A.D. 1400', J. Climate 15, 17541764.

Crawford, M. E. (ed.): 1989, Famine: The Irish Experience 900-1900, Subsistence Crises and Famines in Ireland, John Donald Publishers LTD, Edinburgh, 242 pp.

Crowley, T. J.: 2000, 'Causes of climate change over the past 1000 years', Science 289, 270277.

Crowley, T. J. and Lowery, T. S.: 2000, 'How warm was the Medieval Warm Period?', Ambio 29, $51-54$.

Cubasch, U., Santer, B. D., Hellbach, A., Hegerl, G., Höck, H., Maier-Reimer, E., Mikolajewicz, U., Stössel, A., and Voss, R.: 1994, 'Monte Carlo climate change forecasts with a global coupled ocean-atmosphere model', Clim. Dyn. 10, 1-19.

Cubasch, U., Voss, R., Hegerl, G., Waskewitz, J., and Crowley, T. J.: 1997, 'Simulation of the influence of solar radiation variations on the global climate with an ocean-atmosphere general circulation model', Clim. Dyn. 13, 757-767.

Daley, R.: 1993, Atmospheric Data Analysis, Cambridge University Press, New York, 457 pp.

Dawson, A. G., Hickey, K., McKenna, J., and Foster, I. D. L.: 1997, 'A 200-year record of gale frequency, Edinburgh, Scotland: possible link with high-magnitude volcanic eruptions', Holocene 7, 337-341.

de Kraker, A. M. J.: 1999, 'A method to assess the impact of high tides, storms and storm surges as vital elements in climatic history: The case of stormy weather and dikes in the northern part of Flanders, 1488 to 1609 ', Clim. Change 43, 287-302.

de Kraker, A. M. J.: 2002, 'Historic storms in the North Sea area, an assessment of the storm data, the present position of research and the prospects for future research', in Wefer, G., Berger, W. H., Behre, K.-E., and Jansen, E. (eds.), Climate Development and History in the North Atlantic Realm, Springer-Verlag, Berlin, Heidelberg, New York, Barcelona, Hong Kong, London, Milan, Paris, Tokyo, pp. 415-434.

Demarée, G. R.: 1996, 'The neo-hippocratic hypothesis - an integrated 18th century view on medicine, climate and environment', Zeszyty Naukowe Uniwersytetu Jagiellońskiego - Prace Geograficzne 102, 515-518.

Demarée, G. R. and Ogilvie, A. E. J.: 2001, 'Bons Baisers d'Islande: Climatic, Environmental, and Human Dimensions Impacts of the Lakagígar Eruption (1783-1784) in Iceland', in Jones, P. D., Ogilvie, A. E. J., Davies, T. D., and Briffa, K. R. (eds.), History and Climate: Memories of the Future?, Kluwer Academic/Plenum Publishers, New York, Boston, Dordrecht, London, Moscow, pp. 219-246.

Demarée, G. R., Ogilvie, A. E. J., and Zhang, D.: 1998, 'Further documentary evidence of Northern Hemispheric coverage of the great dry fog of 1783', Clim. Change 39, 727-730.

DeMenocal, P. B.: 2001, 'Cultural responses to climate change during the Late Holocene', Science 292, 667-673.

Deutsch, M. and Pörtge, K.-H.: 2002, Hochwasserereignisse in Thüringen, Thüringer Landesanstalt für Umwelt und Geologie, Schriftreihe 63, Jena, 99 pp. 
Deutsch, M., Pörtge, K. H., and Teltscher, H. (eds.): 2000, Beiträge zum Hochwasser/ Hochwasserschutz in Vergangenheit und Gegenwart, Erfurter Geographische Studien 9, Erfurt, 239 pp.

Dietrich, U.: in press, 'Using Java and XML in interdisciplinary research: A new data-gathering tool for historians as used with EuroClimHist', Historical Methods.

Dobrovolný, P. and Brázdil, R.: 2003, 'Documentary evidence on strong winds related to convective storms in the Czech Republic since AD 1500', Atmos. Res. 67/68, 95-116.

Dufour, M. L.: 1870, 'Problème de la variation du climat', Bulletin de la Société Vaudoise des Sciences naturelles 10, 359-556.

Durkheim, E.: 1982, The Rules of Sociological Method: And Selected Texts on Sociology and Its Method, Macmillan, London, $264 \mathrm{pp}$.

Easton, C.: 1928, Les hivers dans l'Europe occidentale, E. J. Brill, Leyde, 210 pp.

Egger, C. and Weigelt, H.: 2000, Text-Schrift-Codex, Oldenbourg, 391 pp.

Esper, J., Cook, E. R., and Schweingruber, F. H.: 2002, 'Low-frequency signals in long tree-ring chronologies for reconstructing past temperature variability', Science 295, 22502253.

Evans, M. N., Kaplan, A., and Cane, M. A.: 1998, 'Optimal sites for coral-based reconstruction of global sea surface temperature', Paleoceanography 13, 502-516.

Fagan, B.: 2000, The Little Ice Age. How climate made history 1300-1850, Basic Books, New York, $246 \mathrm{pp}$.

Fairbridge, R. W.: 1987, 'Climate variation, historical record', in Oliver, J. E. and Fairbridge, R. W. (eds.), The Encyclopedia of Climatology, Van Nostrand Reinhold Company, New York, pp. 305323.

Faulstich, W.: 1996, Medien und Öffentlichkeit im Mittelalter 800-1400, Vandenhoek und Ruprecht, Göttingen, 298 pp.

Favier, R. and Granet-Abisset, A. M. (eds.): 2000, Histoire et Mémoire des risques naturels, in Actes du séminaire international: Histoire et Mémoire des risques naturels en région de montagne 2526-22-1999, Grenoble, 281 pp.

Fischer-Bruns, I., Cubasch, U., von Storch, H., Zorita, E., Gonzáles-Rouco, F., and Luterbacher, J.: 2002, 'Modelling the Late Maunder Minimum with a 3-dimensional OAGCM', CLIVAR Exchanges 7, 59-61.

Fleming, J. R.: 1998, Historical Perspectives on Climate Change, Oxford University Press, Oxford, $194 \mathrm{pp}$.

Flohn, H.: 1979, 'Zwei Bayerische Wetterkalender aus der Reformationszeit', in Mayer, H., Gietl, G., and Enders, G. (eds.), Festschrift Albert Baumgartner, Wissenschaftliche Mitteilungen des Meteorologischen Instituts der Universität München 35, pp. 173-177.

Flohn, H.: 1981, 'Short-term climatic fluctuations and their economic role', in Wigley, T. M. L., Ingram, M. J., and Farmer, G. (eds.), Climate and History. Studies in past climates and their impact on Man, Cambridge University Press, Cambridge, London, New York, New Rochelle, Melbourne, Sydney, pp. 310-318.

Flohn, H.: 1985, 'A critical assessment of proxy data for climatic reconstruction', in Tooley, M. J. and Sheail, G. M. (eds.), The Climatic Scene. Essays in Honour of Gordon Manley, George Allen \& Unwin, London, pp. 93-103.

Flohn, H.: 1993, 'Climatic evolution during the last millennium: What can we learn from it?', in Eddy, J. A. and Oeschger, H. (eds.), Global Changes in the Perspective of the Past, John Wiley \& Sons, Chichester, New York, Brisbane, Toronto, Singapore, pp. 295-316.

Flückiger-Strebel, E.: 2002, Zwischen Wohlfahrt und Staatsökonomie. Armenfürsorge auf der bernischen Landschaft im 18. Jahrhundert, Chronos, Zürich, 425 pp.

Frenzel, B., Pfister, C., and Gläser, B. (eds.): 1992, European Climate Reconstructed from Documentary Data: Methods and Results, Gustav Fischer Verlag, Stuttgart, Jena, New York, $265 \mathrm{pp}$. 
Frenzel, B., Pfister, C., and Gläser, B. (eds.): 1994, Climatic Trends and Anomalies in Europe 16751715. High Resolution Spatio-Temporal Reconstructions from Direct Meteorological Observations and Proxy Data. Methods and Results, Gustav Fischer Verlag, Stuttgart, Jena, New York, $480 \mathrm{pp}$.

Frisinger, H. H.: 1977, The History of Meteorology: to 1800, Science History Publications, New York, $148 \mathrm{pp}$.

Frydendahl, K. and Frich, P.: 1996, '50,000 weather observations from Danish logbooks 1675-1715', in Pedersen, E. S. (ed.), North European Climate Data in the Latter Part of the Maunder Minimum Period A.D. 1675-1715, AmS Varia 25, pp. 27-31.

Garcia, R. R., Díaz, H. F., García Herrera, R., Eischeid, J., del R. Prieto, M., Hernández, E., Gimeno, L., Durán, F. R., and Bascary, A. M.: 2001, 'Atmospheric circulation changes in the Tropical Pacific inferred from the voyages of the Manila galleons in the sixteenth-eighteenth centuries', Bull. Am. Meteorol. Soc. 82, 2435-2455.

García, R., Gimeno, L., Hernández, E., Prieto, R., and Ribera, P.: 2000, 'Reconstructing the North Atlantic atmospheric circulation in the 16th, 17th and 18th centuries from historical sources', Clim. Res. 14, 147-151.

García, R., Macias, A., Gallego, D., Hernández, E., Gimeno, L., and Ribera, P.: 2003, 'Reconstruction of the precipitation in the Canary Islands for the period 1595-1836', Bull. Am. Meteorol. Soc. 84, ES68-ES77.

Geurts, H. A. M. and van Engelen, A. F. V.: 1992, Beschrijving antieke meetreeksen, Koninklijk Nederlands Meteorologisch Instituut 165-V, De Bilt, 310 pp.

Glacken, C. J.: 1967, Traces on the Rhodian Shore, University of California Press, Berkeley, Los Angeles, London, 763 pp.

Glaeser, B.: 1994, 'Soziologie der Umwelt: Misere, Traditionen, Perspektive', in Huib, E. (ed.), Pathways to Human Ecology, from Observation to Commitment, Lang, Bern, pp. 115-132.

Glaser, R.: 1991, Klimarekonstruktion für Mainfranken, Bauland und Odenwald anhand direkter und indirekter Witterungsdaten seit 1500, Gustav Fischer Verlag, Stuttgart, New York, 175 pp.

Glaser, R.: 1996, Beiträge zur Historischen Klimatologie in Mitteleuropa seit dem Jahr 1000, Habilitationsschrift zur Erlangung der Veni Legendi, Geographisches Institut der Universität Würzburg, $510 \mathrm{pp}$.

Glaser, R.: 1997, 'On the course of temperature in central Europe since the year 1000 AD', Hist. Soc. Res. 22, 59-87.

Glaser, R.: 1998, 'Historische Hochwässer im Maingebiet - Möglichkeiten und Perspektiven auf der Basis der Historischen Klimadatenbank Deutschland (HISKLID)', Erfurter Geogr. Studien 7, 109-128.

Glaser, R.: 2001, Klimageschichte Mitteleuropa. 1000 Jahre Wetter, Klima, Katastrophen, Primus Verlag, Darmstadt, 227 pp.

Glaser, R., Beyer, U., and Beck, C.: 1999a, 'Die Temperaturentwicklung in Mitteleuropa seit dem Jahr 1000 auf der Grundlage quantifizierter historischer Quellentexte', Tübinger Geogr. Studien 125, 23-46.

Glaser, R., Brázdil, R., Pfister, C., Dobrovolný, P., Barriendos Vallvé, M., Bokwa, A., Camuffo, D., Kotyza, O., Limanówka, D., Rácz, L., and Rodrigo, F. S.: 1999b, 'Seasonal temperature and precipitation fluctuations in selected parts of Europe during the sixteenth century', Clim. Change 43, 169-200.

Groh, D., Kempe, M., and Mauelshagen, F. (eds.): 2003, Naturkatastrophen. Beiträge zu ihrer Deutung, Wahrnehmung und Darstellung in Text und Bild von der Antike bis ins 20. Jahrhundert, Gunter Narr Verlag, Tübingen, 242 pp.

Grotefend, H.: 1982, Taschenbuch der Zeitrechnung des deutschen Mittelalters und der Neuzeit, 12th edn., Hahn, Hannover, 223 pp.

Grove, J.: 1988, The Little Ice Age, Methuen \& Co., London, 498 pp. 
Grove, J. M.: 2001a, 'The initiation of the "Little Ice Age" in regions round the North Atlantic', Clim. Change 48, 53-82.

Grove, J.: 2001b, 'The onset of the Little Ice Age', in Jones, P. D., Ogilvie, A. E. J., Davies, T. D., and Briffa, K. R. (eds.), History and Climate: Memories of the Future?, Kluwer Academic/Plenum Publishers, New York, Boston, Dordrecht, London, Moscow, pp. 153-185.

Grove, J. M. and Battagel, A.: 1983, 'Tax records from western Norway, as an index of Little Ice Age environmental and economic deterioration', Clim. Change 5, 265-282.

Grove, J. M. and Conterio, A.: 1995, 'The climate of Crete in the sixteenth and seventeenth centuries', Clim. Change 30, 223-247.

Grove, J. M. and Switsur, R.: 1994, 'Glacial geological evidence for the Medieval Warm Period', Clim. Change 26, 143-169.

Guiot, J.: 1992, 'The combination of historical documents and biological data in the reconstruction of climate variations in space and time', in Frenzel, B., Pfister, C., and Gläser, B. (eds.), European Climate Reconstructed from Documentary Data: Methods and Results, Gustav Fischer Verlag, Stuttgart, Jena, New York, pp. 93-104.

Hagedorn, H. and Glaser, R.: 1990, 'Zur methodischen Konzeption und Regionalisierung in der Paläoklimatologie', Berliner Geogr. Abh. 53, 251-260.

Hansen, J. and Lebedeff, S.: 1987, 'Global trends of measured surface temperature', J. Geophys. Res. 92, 13,345-13,372.

Hansen, J., Ruedy, R., Glascoe, J., and Sato, M.: 1999, 'GISS analysis of surface temperature change', J. Geophys. Res. 104, 30,997-31,022.

Hansen, J., Ruedy, R., Sato, M., Imhoff, M., Lawrence, L., Easterling, D., Peterson, T., and Karl, T.: 2001, 'A closer look at United States and global surface temperature change', J. Geophys. Res. 106, 23,947-23,963.

Hasselmann, K.: 1976, 'Stochastic climate models. Part I. Theory', Tellus 28, 473-485.

Hellmann, G.: 1914, 'Die Vorläufer der Societas Meteorologica Palatina', Beiträge zur Geschichte der Meteorologie 1, 139-147.

Hellmann, G.: 1921, Die Meteorologie in den deutschen Flugschriften und Flugblättern des XVI. Jahrhunderts, Abhandlungen der Preussischen Akademie der Wissenschaften, Physikalischmathematische Klasse 1,96 pp.

Hellmann, G.: 1926, Die Entwicklung der meteorologischen Beobachtungen in Deutschland von den ersten Anfängen bis zur Einrichtung staatlicher Beobachtungsnetze, Abhandlungen der Preussischen Akademie der Wissenschaften, Physikalisch-mathematische Klasse 1, 25 pp.

Hennig, R.: 1904, Katalog bemerkenswerter Witterungsereignisse von den ältesten Zeiten bis zum Jahre 1800, Abh. Königl. Preuss. Meteorol. Inst. 2, Berlin, 93 pp.

Hesselink, A. W.: 2002, History makes a river. Morphological changes and human interference in the river Rhine, The Netherlands, University of Utrecht, Utrecht, 346 pp.

Hickey, K. R.: 2003, 'The storminess record from Armagh Observatory, Northern Ireland, 17961999', Weather 58, 28-35.

Hirschboeck, K. K.: 1987, 'Catastrophic flooding and atmospheric circulation anomalies', in Mayer, L. and Nash, D. B. (eds.), Catastrophic Flooding, Allen \& Unwin, Boston, pp. 23-56.

Holzhauser, H.: 1997, 'Fluctuations of the Grosser Aletsch Glacier and the Gorner Glacier during the last 3200 years: New results', in Frenzel, B., Boulton, G. S., Gläser, B., and Huckriede, U. (eds.), Glacier Fluctuations During the Holocene, Gustav Fischer Verlag, Stuttgart, Jena, Lübeck, Ulm, pp. $35-58$.

Holzhauser, H.: 2002, 'Dendrochronologische Auswertung fossiler Hölzer zur Rekonstruktion der nacheiszeitlichen Gletschergeschichte', Schweizerische Zeitschrift für Forstwesen 15, 317 337.

Holzhauser, H. and Zumbühl, H.: 1999, 'Holocene glacial fluctuations', in Spreafico, M., Weingartner, R., and Leibundgut, C. (eds.), Hydrological Atlas of Switzerland, No. 3.8, Bern. 
Houghton, J. T., Ding, Y., Griggs, D. J., Noguer, M., van der Linden, P. J., Dai, X., Maskell, K., and Johnson, C. A. (eds.): 2001, Climate Change 2001: The Scientific Basis, Cambridge University Press, Cambridge, 881 pp.

Houghton, J. T., Meira Filho, L. G., Callander, B. A., Harris, N., Kattenberg, A., and Maskell, K. (eds.): 1996, Climate Change 1995. The Science of Climate Change, Cambridge University Press, Cambridge, 572 pp.

Hsü, K. J.: 2000, Klima macht Geschichte. Menschheitsgeschichte als Abbild der Klimaentwicklung, Orell Füssli, Zürich, 334 pp.

Huang, S., Pollack, H. N., and Shen, P.-Y.: 2000, 'Temperature trends over the past five centuries reconstructed from borehole temperatures', Nature 403, 756-758.

Hughes, M. K. and Diaz, H. F. (eds.): 1994a, The Medieval Warm Period, Kluwer Academic Publishers, Dordrecht, Boston, London, pp. 109-342.

Hughes, M. K. and Diaz, H. F.: 1994b, 'Was there a 'Medieval Warm Period' and if so, where and when?', Clim. Change 26, 109-142.

Huntington, E.: 1907, The Pulse of Asia. A Journey in Asia Illustrating the Geographical Basis of History, Houghton Mifflin, Boston, 245 pp.

Huntington, E.: 1925, Civilization and Climate, Yale University Press, New Heaven, 453 pp.

Ingram, M. J., Underhill, D. J., and Farmer, G.: 1981, 'The use of documentary sources for the study of past climates', in Wigley, T. M. L., Ingram, M. J., and Farmer, G. (eds.), Climate and History. Studies in past climates and their impact on Man, Cambridge University Press, Cambridge, London, New York, New Rochelle, Melbourne, Sydney, pp. 180-213.

Ingram, M. J., Underhill, D. J., and Wigley, T. M. L.: 1978, 'Historical climatology', Nature 276, 329-334.

Jacobeit, J.: 1997, 'Atlantisch-europäische Bodenluftdruckfelder ombrothermisch anomaler Monate in Mitteleuropa als Hilfsmittel für die synoptische Interpretation analoger Anomalien im historischen Klima und in zukünftigen Klimaszenarien', Petermanns Geographische Mitteilungen 141, 139144.

Jacobeit, J., Glaser, R., Luterbacher, J., and Wanner, H.: 2003, 'Links between flood events in central Europe since AD 1500 and large-scale atmospheric circulation modes', Geophys. Res. Lett. 30, 21-1-21-4.

Jacobeit, J., Jönsson, P., Bärring, L., Beck, C., and Ekström, M.: 2001, 'Zonal indices for Europe 1780-1995 and running correlations with temperature', Clim. Change 48, 219-241.

Jacobeit, J., Wanner, H., Koslowski, G., and Gudd, M.: 1999, 'European surface pressure patterns for months with outstanding climatic anomalies during the sixteenth century', Clim. Change 43, 201-221.

Jakubowski-Tiessen, M. and Lehmann, H. (eds.): 2003, Um Himmels Willen. Religion in Katastrophenzeiten, Vandenhoeck, Göttingen, 358 pp.

Jankovic, V.: 2000, Reading the skies. A cultural history of English Weather, 1650-1820, Manchester University Press, Manchester, 272 pp.

Jevrejeva, S.: 2001, 'Severity of winter seasons in the northern Baltic Sea during 1529-1990', Clim. Res. 17, 55-62.

Jevrejeva, S. and Moore, J. C.: 2001, 'Singular Spectrum Analysis of Baltic Sea ice conditions and large-scale atmospheric patterns since 1708', Geophys. Res. Lett. 28, 4503-4506.

Jones, P. D.: 2001, 'Early European instrumental records', in Jones, P. D., Ogilvie, A. E. J., Davies, T. D., and Briffa, K. R. (eds.), History and Climate: Memories of the Future?, Kluwer Academic/Plenum Publishers, New York, Boston, Dordrecht, London, Moscow, pp. 55-77.

Jones, P. D. and Bradley, R. S.: 1992, 'Climatic variations over the last 500 years', in Bradley, R. S. and Jones, P. D. (eds.), Climate Since A.D. 1500, Routledge, London and New York, pp. 649-665.

Jones, P. D., Bradley, R. S., and Jouzel, J. (eds.): 1996, Climatic Variations and Forcing Mechanisms of the Last 2000 Years, NATO ASI Series, Springer, Berlin, Heidelberg, New York, 649 pp. 
Jones, P. D., Briffa, K. R., Barnett, T., and Tett, S.: 1998, 'High resolution paleoclimatic records for the last millennium: Interpretation, integration and comparison with General Circulation Model control-run temperature', Holocene 8, 455-471.

Jones, P. D., Briffa, K. R., and Osborn, T. J.: 2003a, 'Changes in the Northern Hemisphere annual cycle: Implications for paleoclimatology?', J. Geophys. Res. 108, ACL 13-1-13-7.

Jones, P. D. and Lister, D. H.: 2002, 'The daily air temperature record for St. Petersburg (1743-1996), Clim. Change 53, 253-267.

Jones, P. D., New, M., Parker, D. E., Martin, S., and Rigor, I. G.: 1999, 'Surface air temperature and its changes over the past 150 years', Rev. Geophys. 37, 173-199.

Jones, P. D., Ogilvie, A. E. J., and Wigley, T. M. L.: 1984, Riverflow Data for the United Kingdom: Reconstructed Data Back to 1844 and Historical Data Back to 1556, Climatic Research Unit, Norwich, 157 pp.

Jones, P. D., Osborn, T. J., and Briffa, K. R.: 2001, 'The evolution of climate over the last millennium', Science 292, 662-667.

Jones, P. D., Osborn, T. J., and Briffa, K. R.: 2003b, 'Pressure-based measures of the NAO: A comparison and an assessment of changes in the strength of the NAO and in its influence on surface climate parameters', in Hurrell, J. W., Visbeck, M., Kushnir, Y., and Ottersen, G. (eds.), The North Atlantic Oscillation: Climatic Significance and Environmental Impact, American Geophysical Union, Washington, pp. 51-62.

Jones, P. D., Raper, S. C. B., Bradley, R. S., Diaz, H. F., Kelly, P. M., and Wigley, T. M. L.: 1986, 'Northern Hemisphere surface air temperature variations: 1851-1984', J. Climatol. Appl. Meteorol. 25, $161-179$.

Jurin, J.: 1723, 'Invitatio ad Observationes Meteorologicas communi consilio instituendas', Philosophical Transactions 32, 422-427.

Kaas, E., Tian-shi, L., and Schmith, T.: 1996, 'Statistical hindcast of wind climatology in the north Atlantic and north-western European region', Clim. Res. 7, 97-110.

Kachelmann, J.: 2002, Die grosse Flut. Unser Klima, unsere Umwelt, unsere Zukunft, Rowohlt, Hanburgh, 270 pp.

Kajander, J.: 1993, 'Methodological aspects on river cryophenology exemplified by a tricentennial break-up time series from Tornio', Geophysica 29, 73-95.

Kanold, J.: 1718-1727, Sammlung von Natur- und Medicin-, wie auch hierzu gehörigen Kunst- und Literatur-Geschichten, Breslau.

Kaplan, A., Kushnir, Y., Cane, M. A., and Blumenthal, M. B.: 1997, 'Reduced space optimal analysis for historical datasets: 136 years of Atlantic sea surface temperature', J. Geophys. Res. 102, $27,835-27,860$.

Karl, T. S. and Easterling, D. R.: 1999, 'Climate extremes: Selected review and future research directions', Clim. Change 42, 309-325.

Kates, R. W.: 1985, 'The interaction of climate and society', in Kates, R. W., Ausubel, J. H., and Berberian, M. (eds.), Climate Impact Assessment. Studies of the Interaction of Climate and Society, Wiley, Chichester, New York, Brisbane, Toronto, Singapore, pp. 3-36.

Kempe, M.: 2003, 'Noah's flood: The genesis story and natural disasters in Early Modern Times', Environ. Hist. 9, 151-171.

Kempe, M. and Rohr, C.: 2003, 'Coping with the unexpected natural disasters and their perception in history', Environ. Hist. 9 (Special Issue), 128 pp.

Kington, J.: 1988, The Weather of the 1780s over Europe, Cambridge University Press, Cambridge, $166 \mathrm{pp}$.

Kiss, A.: 1999, 'Some weather events in the fourteenth century II (Angevin period: 1301-1387)', Acta Climatol. Univ. Szegediensis 32-33, 51-64.

Kiss, A.: 2000, 'Weather events during the first Tartar invasion in Hungary (1241-42)', Acta Geogr. Szegediensis 37, 149-156. 
Kistler, R., Kalnay, E., Collins, W., Saha, S., White, G., Woollen, J., Chelliah, M., Ebisuzaki, W., Kanamitsu, M., Kousky, V., van den Dool, H., Jenne, R., and Fiorino, M.: 2001, 'The NCEPNCAR 50-year reanalysis: Monthly means CD-ROM and documentation', Bull. Am. Meteorol. Soc. 82, 247-267.

Klingbjer, P. and Moberg, A.: 2003, 'A composite monthly temperature record from Tornedalen in northern Sweden 1802-2002', Int. J. Climatol., 23, 1465-1494.

Kociánová, M.: 2002, 'Otázka projevů chladných období postglaciálu v krkonošské tundře', Opera Concortica 39, 143-151.

Koslowski, G. and Glaser, R.: 1999, 'Variations in reconstructed ice winter severity in the Western Baltic from 1501 to 1995, and their implications for the North Atlantic Oscillation', Clim. Change 41, 175-191.

Krahe, P.: 1997, 'Hochwasser und Klimafluktuationen am Rhein seit dem Mittelalter', in Immendorf, R. (ed.), Hochwasser. Natur im Überfluss?, C. F. Müller, Heidelberg, pp. 5782.

Lamb, H. H.: 1965, 'The early medieval warm epoch and its sequel', Palaeogeogr. Palaeoclimatol. Paleoecol. 1, 13-37.

Lamb, H. H.: 1977, Climate: Present, Past and Future, vol. 2: Climatic History and the Future, Methuen, London, 835 pp.

Lamb, H. H.: 1980, 'Weather and climate patterns of the Little Ice Age', in Oeschger, H., Messerli, B., and Svilar, M. (eds.), Das Klima: Analysen und Modelle, Geschichte und Zukunft, Springer-Verlag, Berlin, Heidelberg, New York, pp. 149-160.

Lamb, H. H.: 1982, Climate, History and the Modern World, Methuen, London, 387 pp.

Lamb, H. H.: 1984, 'Climate in the last thousand years: Natural climatic fluctuations and change', in Flohn, H. and Fantechi, R. (eds.), The Climate of Europe: Past, Present and Future, D. Reidel Publishing Company, Dordrecht, Boston, Lancaster, pp. 25-64.

Lamb, H. H.: 1987, 'What can historical records tell us about the breakdown of the Medieval warm climate in Europe in the fourteenth and fifteenth centuries - an experiment', Beitr. Phys. Atmosph. 60, 131-143.

Lamb, H. H.: 1991, Historic Storms of the North Sea, British Isles and Northwest Europe, Cambridge University Press, Cambridge, 204 pp.

Landsteiner, E.: 1999, 'The crisis of wine production in late sixteenth-century central Europe: Climatic causes and economic consequences', Clim. Change 43, 323-334.

Lauer, W.: 1981, Klimawandel und Menschheitsgeschichte auf dem mexikanischen Hochland, Akademie der Wissenschaften und Literatur Mainz, Abhandlungen der mathematischnaturwissenschaftlichen Klasse, No. 2, 49 pp.

Lauer, W. and Frankenberg, P.: 1986, Zur Rekonstruktion des Klimas im Bereich der Rheinpfalz seit Mitte des 16. Jahrhundert mit Hilfe von Zeitreihen der Weinquantität und Weinqualität, Gustav Fischer Verlag, Stuttgart, New York, 54 pp.

Legrand, J.-P. and LeGoff, M.: 1992, Les observations météorologiques de Louis Morin, Monographie 6, Direction de la Météorologie Nationale, Paris, 128 pp.

Lenke, W.: 1964, 'Untersuchungen der ältesten Temperaturmessungen mit Hilfe des strengen Winters 1708-1709', Ber. Deutsch. Wetterd. 92, 3-45.

Lenke, W.: 1968, 'Das Klima Ende des 16. und Anfang des 17. Jahrhunderts nach Beobachtungen von Tycho Brahe auf Hven, Leonhard III Treuttwein in Fürstenfeld und David Fabricius in Ostfriesland', Ber. Deutsch. Wetterd. 110, 49 pp.

Le Roy Ladurie, E.: 1967, L'histoire du climat depuis l'au mil, Flammarion, Paris, 413 pp. English translation: Times of Feast, Times of Famine: A History of Climate Since the Year 1000, George Allen \& Unwin, London 1972, 428 pp.

Le Roy Ladurie, E. and Baulant, M.: 1980, 'Grape harvests from the fifteenth through the nineteenth centuries', J. Interdisciplin. Hist. 10, 839-849. 
Lieth, H.: 1974, Phenology and Seasonal Modeling, Springer-Verlag, Berlin, Heidelberg, New York, $444 \mathrm{pp}$.

Limanówka, D.: 2001, Rekonstrukcja warunków klimatycznych Krakowa w pierwszej polowie XVI wieku, Instytut Meteorologii i Gospodarki Wodnej, Warszawa, $176 \mathrm{pp}$.

Llasat, D. C. M., Rigo, T., and Barriendos, M.: 2003, 'The 'Montserrat-2000' flash-flood event: A comparison with the floods that have occurred in the northeastern Iberian Peninsula since the 14th century', Int. J. Climatol. 23, 453-469.

Luterbacher, J.: 2001, 'The Late Maunder Minimum (1675-1715) - climax of the 'Little Ice Age' in Europe', in Jones, P. D., Ogilvie, A. E. J., Davies, T. D., and Briffa, K. R. (eds.), History and Climate: Memories of the Future?, Kluwer Academic/Plenum Publishers, New York, Boston, Dordrecht, London, Moscow, pp. 29-54.

Luterbacher, J., Dietrich, D., Xoplaki, E., Grosjean, M., and Wanner, H.: 2004, 'European seasonal and annual temperature variability, trends and extremes since 1500', Science 303, 1499-1503.

Luterbacher, J., Rickli, R., Tinguely, C., Xoplaki, E., Schüpbach, E., Dietrich, D., Hüsler, J., Ambühl, M., Pfister, C., Beeli, P., Dietrich, U., Dannecker, A., Davies, T. D., Jones, P. D., Slonosky, V., Ogilvie, A. E. J., Maheras, P., Kolyva-Machera, F., Martín-Vide, J., Barriendos, M., Alcoforado, M. J., Nunes, M. F., Jónsson, T., Glaser, R., Jacobeit, J., Beck, C., Philipp, A., Beyer, U., Kaas, E., Schmith, T., Bärring, L., Jönsson, P., Rácz, L., and Wanner, H.: 2000, 'Monthly mean pressure reconstructions for the Late Maunder Minimum period (AD 1675-1715)', Int. J. Climatol. 20, 1049-1066.

Luterbacher, J., Rickli, R., Xoplaki, E., Tinguely, C., Beck, C., Pfister, C., and Wanner, H.: 2001, 'The Late Maunder Minimum (1675-1715) - a key period for studying climatic variability and decadal scale climate change in Europe', Clim. Change 49, 441-462.

Luterbacher, J., Schmutz, C., Gyalistras, D., Xoplaki, E., and Wanner, H.: 1999, 'Reconstruction of monthly NAO and EU indices back to AD 1675', Geophys. Res. Lett. 26, 2745-2748.

Luterbacher, J. and Xoplaki, E.: 2003, '500-year winter temperature and precipitation variability over the Mediterranean area and its connection to the large-scale atmospheric circulation', in Bolle, H.-J. (ed.), Mediterranean Climate - Variability and Trends, Springer Verlag, Berlin, Heidelberg, New York, pp. 133-153.

Luterbacher, J., Xoplaki, E., Dietrich, D., Jones, P. D., Davies, T. D., Portis, D., Gonzales-Rouco, J. F., von Storch, H., Gyalistras, D., Casty, C., and Wanner, H.: 2002a, 'Extending North Atlantic Oscillation reconstructions back to 1500', Atmos. Sci. Lett. 2, 114-124.

Luterbacher, J., Xoplaki, E., Dietrich, D., Rickli, R., Jacobeit, J., Beck, C., Gyalistras, D., Schmutz, C., and Wanner, H.: 2002b, 'Reconstruction of sea level pressure fields over the eastern North Atlantic and Europe back to 1500', Clim. Dyn. 18, 545-561.

Lyakhov, M. E.: 1992, 'Ekstremalnyye termitcheskiye usloviya v tsentralnoy Rossii i tsentralnoy Evrope v XIII-XIV vekakh', Materialy meteorologitcheskikh issledovaniy 15, 156-170.

Maak, K. and von Storch, H.: 1997, 'Statistical downscaling of monthly mean air temperature to the beginning of the flowering of Galanthus nivalis L. in Northern Germany', Int. J. Biometeorol. 41, $5-12$.

Malewicz, H. M.: 1980, Zjawiska przyrodnicze w relacjach dziejopisarzy polskiego średniowiecza, Ossolineum, Wrocław, Warszawa, Kraków, Gdańsk, 188 pp.

Manley, G.: 1974, 'Central England temperatures: monthly means 1659 to 1973', Quart. J. R. Meteorol. Soc. 100, 389-405.

Mann, M. E.: 2001, 'Climate during the past millennium', Weather 56, 91-102.

Mann, M. E.: 2002, 'The value of multiple proxies', Science 297, 1481-1482.

Mann, M. E., Bradley, R. S., and Hughes, M. K.: 1998, 'Global-scale temperature patterns and climate forcing over the past six centuries', Nature 392, 779-787.

Mann, M. E., Bradley, R. S., and Hughes, M. K.: 1999, 'Northern Hemisphere temperatures during the past millennium: inferences, uncertainties, and limitations', Geophys. Res. Lett. 26, 759-762. 
Mann, M. E., Gille, E., Bradley, R. S., Hughes, M. K., Overpeck, J. T., Keimig, F. T., and Gross, W.: 2000, 'Global temperature patterns in past centuries: An interactive presentation', Earth Interact. 4, 1-29.

Markham, S. F.: 1947, Climate and the Energy of Nations, Oxford University Press, London, New York, Toronto, $240 \mathrm{pp}$.

Martín-Vide, J. and Barriendos, M.: 1995, 'The use of rogation ceremony records in climatic reconstruction: a case study from Catalonia (Spain)', Clim. Change 30, 201-221.

Matthes, F.: 1939, 'Report of Committee on Glaciers', Trans. Am. Geophys. Union 20, 518-523.

Matthes, F.: 1940, 'Committee on Glaciers, 1939-40', Trans. Am. Geophys. Union 21, 396-406.

Maugeri, M., Buffoni, L., and Chlistovsky, F.: 2002a, 'Daily Milan temperature and pressure series (1763-1998): History of the observations and data and metadata recovery', Clim. Change 53, 101-117.

Maugeri, M., Buffoni, L., Delmonte, B., and Fassina, A.: 2002b, 'Daily Milan temperature and pressure series (1763-1998): Completing and homogenising the data', Clim. Change 53, 119-149.

Menzel, A.: 2002, 'Phenology. Its importance to the global change community', Clim. Change 54, 379-385.

Menzel, A. and Estrella, N.: 2001, 'Plant phenological changes', in Walther, G.-R., Burga, C. A., and Edwards, P. J. (eds.), "Fingerprints" of Climate Change. Adapted Behaviour and Shifting Species Ranges, Kluwer Academic Publishers, New York, London, pp. 123-138.

Metcalfe, S. E., del Prieto, M. R., Endfield, G. H., Davies, S. J., and O'Hara, S. L.: 2002, 'The potential of archival sources for reconstructing climate and climate-related processes in Latin America', PAGES News 10, 11-14.

Michaelsen, J.: 1984, 'Cross-validation in statistical climate forecast models', J. Climate 26, 15891600 .

Mikami, T. (ed.): 1992, Proceedings of the International Symposium on the Little Ice Age Climate, Tokyo Metropolitan University, Tokyo, $342 \mathrm{pp}$.

Militzer, S.: 1996, 'Klima-Klimageschichte-Geschichte. Status und Perspektiven von Klimageschichte und Historischer Klimawirkungsforschung', Geschichte in Wissenschaft und_Unterricht 47, 71-88.

Militzer, S.: 1998, 'Sachsen - Klimatatsachen und Umriss von Klimawirkungen im 17. Jahrhundert', in Schirmer, U. (ed.), Sachsen im 17. Jahrhundert: Krise, Krieg und Neubeginn, Sax Verlag, Beucha, pp. 69-100.

Moberg, A., Bergström, H., Ruiz Krigsman, J., and Svanered, O.: 2002, 'Daily air temperature and pressure series for Stockholm (1756-1998)', Clim. Change 53, 171-212.

Moberg, A., Jones, P. D., Barriendos, M., Bergström, H., Camuffo, D., Cocheo, C., Davies, T. D., Demarée, G., Martín-Vide, J., Maugeri, M., Rodriguez, R., and Verhoeve, T.: 2000, 'Day-to day temperature variability trends in 160- to 275-year-long European instrumental records', $J$. Geophys. Res. 205, 22,849-22,868.

Mudelsee, M., Börngen, M., Tetzlaff, G., and Grünewald, U.: 2003, 'No upward trends in the occurrence of extreme floods in central Europe', Nature 425, 166-169.

Munzar, J.: 2001, 'Summer floods in Central Europe in 1813 - an analogy to floods of 1997', Moravian Geogr. Rep. 9, 29-40.

Munzar, J.: 2002, 'Environmetal history of Central Europe in the first half of the 18th century (according to the so-called Wroclaw collection)', Moravian Geogr. Rep. 10, 37-45.

Münchener Rück: 1999, Topics 2000: Natural Catastrophes - The Current Position, Münchener Rück, München, $126 \mathrm{pp}$.

Neumann, J.: 1985, 'Climatic change as a topic in the classical Greek and Roman literature', Clim. Change 7, 441-454.

Newman, L. F. (ed.): 1990, Hunger in History. Food Shortage, Poverty and Deprivation, Basil Blackwell, Oxford, $429 \mathrm{pp}$. 
Nordli, P. Ø.: 2001, 'Reconstruction of nineteenth century summer temperatures in Norway by proxy data from farmers' diaries', Clim. Change 48, 201-218.

Nordli, P. Ø., Lie, Ø., Nesje, A., and Dahl, S. O.: 2002, Spring/Summer Temperature Reconstruction Western Norway 1734-2002, DNMI-Rapport 26/02 Klima, Oslo, 47 pp.

Nordli, P. Ø., Lie, Ø., Nesje, A., and Dahl, S. O.: 2003, 'Spring-summer temperature reconstruction in western Norway 1734-2003: A data-synthesis approach', Int. J. Climatol. 23, 1821-1841.

Ogilvie, A. and Farmer, G.: 1997, 'Documenting the Medieval climate', in Hulme, K. and Barrow, E. (eds.), Climates of the British Isles: Present, Past and Future, Routledge, London and New York, pp. 112-133.

Ogilvie, A. E. J.: 1996, 'Sea-ice conditions off the coasts of Iceland A.D. 1601-1850 with special reference to part of the Maunder Minimum period (1675-1715)', AmS-Varia 25, 9-12.

Ogilvie, A. E. J., Barlow, L. K., and Jennings, A. E.: 2000, 'North Atlantic climate AD 1000: Millennial reflections on the Viking discoveries of Iceland, Greenland and North America', Weather 55, 34 45.

Ogilvie, A. E. J. and Jónsson, T. (eds.): 2001, The Iceberg in the Mist: Northern Research in Pursuit of a "Little Ice Age", Kluwer Academic Publishers, Dordrecht, Boston, London, 263 pp.

Ogrin, D.: 2002, 'Dry and wet years in submediterranean Slovenia from the 14th to the mid-19th century', Acta Univ. Palacki. Olomuc. Fac. Rer. Nat.-Geographica 37, 55-62.

Ornato, E.: 1988, 'L'exploitation des sources narratives médiévales dans l'histoire du climat: à propos d'un ouvrage récent', Histoire \& Mesure 3, 403-449.

Panessa, G.: 1991, Fonti Greche e Latine per la storia dell'ambiente e del clima nel mondo Greco, Scuola Normale Superiore di Pisa, Pisa, vol. 1, pp. 1-541; vol. 2, pp. 542-1024.

Pauling, A., Luterbacher, J., and Wanner, H.: 2003, 'Evaluation of proxies for European and North Atlantic temperature field reconstructions', Geophys. Res. Lett. 30, CLM 2-1-CLM 2-4.

Pedersen, E. S. (ed.): 1996, North European Climate Data in the Latter Part of the Maunder Minimum Period A.D. 1675-1715, Museum of Archaeology Stavanger, 66 pp.

Penzar, I. and Penzar, B.: 1997, 'Weather and climate notes on the Adriatic up to the middle of the 19th century', Geofizika 14, 47-82.

Pfister, C.: 1978, 'Climate and Economy in Eighteenth-Century Switzerland', J. Interdisciplin. Hist. 9, 223-243.

Pfister, C.: 1979, 'Getreide-Erntebeginn und Frühsommertemperaturen im schweizerischen Mittelland seit dem frühen 17. Jahrhundert', Geogr. Helv. 34, 23-25.

Pfister, C.: 1981, 'Die Fluktuationen der Weinmosterträge im Schweizerischen Weinland vom 16. bis ins frühe 19. Jahrhundert', Schweizer Zeitschrift für Geschichte 31, 445-491.

Pfister, C.: 1984, Klimageschichte der Schweiz 1525-1860. Das Klima der Schweiz und seine Bedeutung in der Geschichte von Bevölkerung und Landwirtschaft, Paul Haupt, Bern, 184 pp.

Pfister, C.: 1988a, 'Variations in the spring-summer climate of Central Europe from the High Middle Ages to 1850', in Wanner, H. and Siegenthaler, U. (eds.), Long and Short Term Variability of Climate, Springer-Verlag, Berlin, Heidelberg, New York, London, Paris, Tokyo, pp. 57-82.

Pfister, C.: 1988b, 'Fluctuations du climat et prix céréaliers en Europe 16ème-20ème siècles', Annales E.S.C. $\mathbf{1} / \mathbf{1 9 8 8}, 25-53$.

Pfister, C.: 1992, 'Monthly temperature and precipitation patterns in Central Europe from 1525 to the present. A methodology for quantifying man-made evidence on weather and climate', in Bradley, R. S. and Jones, P. D. (eds.), Climate Since A.D. 1500, Routledge, London and New York, pp. $118-142$.

Pfister, C.: 1999, Wetternachhersage. 500 Jahre Klimavariationen und Naturkatastrophen (14961995), Verlag Paul Haupt, Bern, Stuttgart, Wien, 304 pp.

Pfister, C.: 2001, 'Klimawandel in der Geschichte Europas. Zur Entwicklung und zum Potenzial der historischen Klimatologie', Österreichische Zeitschrift für Geschichtswissenschaften 12, 7 43. 
Pfister, C.: 2002, 'Naturkatastrophen und Naturgefahren in geschichtlicher Perspektive. Ein Einstieg', in Pfister, C. (ed.), Am Tag danach. Zur Bewältigung von Naturkatastrophen in der Schweiz 15002000, Verlag Paul Haupt, Bern, Stuttgart, Wien, pp. 11-26 (also available in French: Le Jour d'après. Surmonter les catastrophes naturelles: le cas de la Suisse enter 1500 et 2000. Berne 2002, traduit par Véronique Mange).

Pfister, C.: in press, 'Weeping in the snow. The second period of Little Ice Age-Type Impacts, 1570 to 1630', in Behringer, W., Lehmann, H., and Pfister, C. (eds.), Kulturelle Konsequenzen der Kleinen Eiszeit - Cultural Consequences of the Little Ice Age, Vandenhoek \& Ruprecht, Göttingen.

Pfister, C. and Bareiss, W.: 1994, 'The climate in Paris between 1675 and 1715 according to the Meteorological Journal of Louis Morin', in Frenzel, B., Pfister, C., and Gläser, B. (eds.), Climatic Trends and Anomalies in Europe 1675-1715, Gustav Fischer Verlag, Stuttgart, Jena, New York, pp. 151-171.

Pfister, C. and Brázdil, R.: 1999, 'Climatic variability in sixteenth-century Europe and its social dimension: A synthesis', Clim. Change 43, 5-53.

Pfister, C., Brázdil, R., and Glaser, R. (eds.): 1999a, Climatic Variability in Sixteenth-Century Europe and its Social Dimension, Kluwer Academic Publishers, Dordrecht, Boston, London, 351 pp.

Pfister, C., Brázdil, R., Glaser, R., Barriendos, M., Camuffo, D., Deutsch, M., Dobrovolný, P., Enzi, S., Guidoboni, E., Kotyza, O., Militzer, S., Rácz, L., and Rodrigo, F. S.: 1999b, 'Documentary evidence on climate in sixteenth-century Europe', Clim. Change 43, 55-110.

Pfister, C., Brázdil, R., Glaser, R., Bokwa, A., Holawe, F., Limanowka, D., Kotyza, O., Munzar, J., Rácz, L., Strömmer, E., and Schwarz-Zanetti, G.: 1999c, 'Daily weather observations in sixteenthcentury Europe', Clim. Change 43, 111-150.

Pfister, C., Brázdil, R., Obrebska-Starkel, B., Starkel, L., Heino, R., and von Storch, H.: 2001, 'Strides made in reconstructing past weather and climate', Eos - Transactions American Geophysical Union 82, 248

Pfister, C. and Brändli, D.: 1999, 'Rodungen im Gebirge - Überschwemmungen im Vorland: Ein Deutungsmuster macht Karriere', in Sieferle, R. P. and Greunigener, H. (eds.), Natur-Bilder. Wahrnehmungen von Natur und Umwelt in der Geschichte, Campus Verlag, Frankfurt, New York, pp. 9-18.

Pfister, C. and Hächler, S.: 1991, 'Überschwemmungskatastrophen im Schweizer Alpenraum seit dem Spätmittelalter. Raum-zeitliche Rekonstruktion von Schadenmustern auf der Basis historischer Quellen', in Glaser, R. and Walsh, R. (eds.): Historische Klimatologie in verschiedenen Klimazonen, Würzburger Geographische Arbeiten 80, Würzburg, pp. 127-148.

Pfister, C., Kington, J., Kleinlogel, G., Schüle, H., and Siffert, E.: 1994, 'High resolution spatiotemporal reconstructions of past climate from direct meteorological observations and proxy data', in Frenzel, B., Pfister, C., and Gläser, B. (eds.), Climatic Trends and Anomalies in Europe 16751715, Gustav Fischer Verlag, Stuttgart, Jena, New York, pp. 329-375.

Pfister, C., Luterbacher, J., Schwarz-Zanetti, G., and Wegmann, M.: 1998, 'Winter air temperature variations in western Europe during the Early and High Middle Ages (AD 750-1300)', Holocene $8,535-552$.

Pfister, C., Schwarz-Zanetti, G., and Wegmann, M.: 1996, 'Winter severity in Europe: the fourteenth century', Clim. Change 34, 91-108.

Piervitali, E. and Colacino, M.: 2001, 'Evidence of drought in Western Sicily during the period 1565-1915 from liturgical offices', Clim. Change 49, 225-238.

Popova, V. V.: 2001, 'Kolebaniya osadkov na Russkoy ravnine za posledneye tysyatcheletiye', Izvestiya Akademii Nauk - Ser. Geogr. 2001, 42-49.

Porter, S. C.: 1986, 'Pattern and forcing of Northern Hemisphere glacier variations during the last millennium', Quarter. Res. 26, 27-48.

Pötzsch, C. G.: 1784, Chronologische Geschichte der grossen Wasserfluthen des Elbstroms, Walther, Dresden, 232 pp. 
Pozo-Vazquez, D., Esteban-Parra, M. J., Rodrigo, F. S., and Castro-Díez, Y.: 2001, 'A study of NAO variability and its possible non-linear influences on European surface temperature', Clim. Dyn. 17, 701-715.

Proctor, C. J., Baker, A., and Barnes, W. L.: 2002, 'A three thousand year record of N Atlantic climate', Clim. Dyn. 19, 449-454.

Proctor, C. J., Baker, A., Barnes, W. L., and Gilmour, M. A.: 2000, 'A thousand year speleothem proxy record of North Atlantic climate from Scotland', Clim. Dyn. 16, 815-820.

Quinlan, F. T., Karl, T. R., and Williams, C. N. Jr.: 1987, United States Historical Climatology Network $(H C N)$ serial temperature and precipitation data, NDP019. Carbon Dioxide Information Analysis Center, Oak Ridge National Laboratory, Oak Ridge, Tennessee.

Rácz, L.: 1999, Climate History of Hungary Since 16th Century: Past, Present and Future, Centre for Regional studies of Hungarian Academy of Sciences, Pécs, 158 pp.

Rebetez, M.: 1996, 'Public expectation as an element of human perception of climate change', Clim. Change 32, 495-509.

Rebetez Beniston, M.: 1992, Perception du temps et du climat: une analyse du climat de suisse romande sur la base des dictions populaires, Editions Stratus, Oron-la-Ville, 102 pp.

Repapis, C. C., Schuurmans, C. J. E., Zerefos, C. S., and Ziomas, J.: 1989, 'A note on the frequency of occurrence of severe winters as evidenced in monastery and historical records from Greece during the period 1200-1900 A.D.', Theor. Appl. Climatol. 39, 213-217.

Retsö, D.: 2002, 'A contribution to the history of European winters: Some climatological proxy data from early-sixteenth century Swedish documentary sources', Clim. Change 52, 137173.

Robinson, A. R., Lermusiaux, P. F. J., and Sloan III, N. Q.: 1998, 'Data assimilation', in Brink, K. H. and Robinson, A. R. (eds.), The Global Coastal Ocean. Processes and Methods. The Sea, vol. 10, John Wiley \& Sons Inc., New York, pp. 541-593.

Rodrigo, F. S., Esteban-Parra, M. J., and Castro-Diez, Y.: 1995, 'The onset of the Little Ice Age in Andalusia (southern Spain): Detection and characterization from documentary sources', Annales Geophysicae 13, 330-338.

Rodrigo, F. S., Esteban-Parra, M. J., and Castro-Diez, Y.: 1998, 'On the use of the Jesuit order private correspondence records in climate reconstructions: A case study from Castille (Spain) for 1634-1648 A.D.', Clim. Change 40, 625-645.

Rodrigo, F. S., Esteban-Parra, M. J., Pozo-Vázquez, D., and Castro-Díez, Y.: 1999, ‘A 500-year precipitation record in Southern Spain', Int. J. Climatol. 19, 1233-1253.

Rodrigo, F. S., Pozo-Vazquez, D., Esteban-Parra, M. J., and Castro-Diez, Y.: 2001, 'A reconstruction of the winter North Atlantic Oscillation Index back to AD 1501 using documentary data in southern Spain', J. Geophys. Res. 106, 14,805-14,818.

Rutherford, S., Mann, M. E., Delworth, T. L., and Stouffer, R. J.: 2003, 'Climate field reconstruction under stationary and nonstationary forcing', J. Climate 16, 462-479.

Sarewitz, D. and Pielke, R., Jr.: 2000, 'Breaking the Global-Warming gridlock', Atlant. Mon. July 2000, 55-64.

Schiesser, H. H., Pfister, C., and Bader, J.: 1997, 'Winter storms in Switzerland north of the Alps 1864/1865-1993/1994', Theor. Appl. Climatol. 58, 1-9.

Schmidt, M.: 2000, Hochwasser und Hochwasserschutz in Deutschland vor 1850. Eine Auswertung alter Quellen und Karten, Oldenbourg-Industrieverlag, München, $350 \mathrm{pp}$.

Schmutz, C., Luterbacher, J., Gyalistras, D., Xoplaki, E., and Wanner, H.: 2000, 'Can we trust proxybased NAO reconstructions', Geophys. Res. Lett. 27, 1135-1138.

Schwarz-Zanetti, G.: 1998, Grundzüge der Klima- und Umweltgeschichte des Hoch- und Spätmittelalters in Mitteleuropa, Studentendruckerei Zürich, Zürich, $131 \mathrm{pp}$.

Semple, E. C.: 1911, Influences of Geographic Environment, on the Basis of Ratzel's System of Anthropo-Geography, Holt, Rinehart and Winston, New York, 170 pp. 
Shabalova, M. V. and van Engelen, A. F. V.: 2003, 'Evaluation of a reconstruction of winter and summer temperatures in the Low countries', Clim. Change 58, 219-242.

Shindell, D. T., Schmidt, G. A., Mann, M. E., Rind, D., and Waple, A.: 2001, 'Solar forcing of regional climate change during the Maunder Minimum', Science 294, 2149-2152.

Shindell, D. T., Schmidt, G. A., Miller, R. L., and Mann, M. E.: 2003, 'Volcanic and solar forcing of climate change during the preindustrial era', J. Climate 16, 4094-4107.

Slonosky, V. C.: 2002, 'Wet winters, dry summers? Three centuries of precipitation data from Paris', Geophys. Res. Lett. 29, 1-1-1-4.

Slonosky, V. C., Jones, P. D., and Davies, T. D.: 2001, 'Instrumental pressure observation from the 17th and 18th centuries: London and Paris', Int. J. Climatol. 21, 285-298.

Slonosky, V. C. and Yiou, P.: 2002, 'Does the NAO index represent zonal flow? The influence of the NAO on North Atlantic surface temperature', Clim. Dyn. 19, 17-30.

Soon, W. and Baliunas, S.: 2003, 'Proxy climatic and environmental changes of the past 1000 years', Clim. Res. 23, 89-110.

Souriau, A. and Yiou, P.: 2001, 'Grape harvest dates for checking NAO paleoreconstructions', Geophys. Res. Lett. 28, 3895-3898.

Sparks, T. H. and Carey, P. D.: 1995, 'The responses of species to climate over two centuries: An analysis of the Marsham Phenological Record 1736-1947', J. Ecol. 83, 321-329.

Stathakopoulos, D.: 2003, 'Reconstructing the climate of the Byzantine world: State of the problem and case studies', in Laszlovszky, J. and Szabó, P. (eds.), People and Nature in Historical Perspective, Central European University and Archeolingua Publishing House, Budapest, pp. 247-261.

Stehr, N. and von Storch, H.: 1995, 'The social construct of climate and climate change', Clim. Res. 5, 99-105.

Stehr, N. and von Storch, H.: 2000a, Eduard Brückner - The Sources and Consequences of Climate Change and Climate Variability in Historical Times, Kluwer Academic Publishers, Dordrecht, Boston, London, $338 \mathrm{pp}$.

Stehr, N. and von Storch, H.: 2000b, 'Von der Macht des Klimas. Ist der Klimadeterminismus nur noch Ideengeschichte oder relevanter Faktor gegenwärtiger Klimapolitik?', Gaia 9, 187-195.

Stine, S.: 1998, 'Medieval climatic anomaly in the Americas', in Issar, A. S. and Brown, N. (eds.), Water, Environment and Society in Times of Climatic Change, Kluwer Academic Publishers, Dordrecht, Boston, London, pp. 43-67.

Stothers, R. B.: 1996, 'The great dry fog of 1783', Clim. Change 32, 79-89.

Stothers, R. B.: 1999, 'Volcanic dry fogs, climate cooling and plague pandemics in Europe and the Middle East', Clim. Change 42, 713-723.

Stothers, R. B.: 2000, 'Climatic and demographic consequences of the massive volcanic eruption of 1258', Clim. Change 45, 361-374.

Strnadt, A.: 1790, Chronologische Verzeichniss der Naturbegebenheiten im Königreiche Böhmen, vom Jahre Christi 633 bis 1700, Gerrlische Buchhandlung, Prag, 123 pp.

Strömmer, E.: 2003, Klima-Geschichte. Methoden der Rekonstruktion und historische Perspektive. Ostösterreich 1700 bis 1830, Franz Deuticke, Wien, 325 pp.

Střeštík, J. and Verö, J.: 2000, 'Reconstruction of the spring temperatures in the 18th century based on the measured lengths of grapevine sprouts', Idöjárás 104, 123-136.

Stuber, M.: 2003, 'Divine punishment or object of research? The resonance of earthquakes, floods, epidemics and famine in the correspondence network of Albrecht von Haller', Environ. Hist. 9, 173-193.

Sturm, K., Glaser, R., Jacobeit, J., Deutsch, M., Brázdil, R., Pfister, C., Luterbacher, J., and Wanner, H.: 2001, 'Hochwasser in Mitteleuropa seit 1500 und ihre Beziehungen zur atmosphärischen Zirkulation', Petermanns Geographische Mitteilungen 145, 14-23.

Sweeney, J.: 2000, 'A three-century storm climatology for Dublin 1715-2000', Irish Geography 33, $1-14$. 
Tarand, A. and Kuiv, P.: 1994, 'The beginning of the rye harvest-a proxy indicator of summer climate in the Baltic area', in Frenzel, B., Pfister, C., and Gläser, B. (eds.), Climatic Trends and Anomalies in Europe 1675-1715, Gustav Fischer Verlag, Stuttgart, Jena, New York, pp. 6172.

Tarand, A. and Nordli, P. Ø.: 2001, 'The Tallinn temperature series reconstructed back half a millennium by use of proxy data', Clim. Change 49, 189-199.

Telelis, I. G.: 1998, 'The climate of Tübingen A.D. 1596-1605, on the basis of Martin Crusius' Diarium', Environ. Hist. 4, 53-74.

Telelis, I.: 2000, 'Medieval Warm Period and the beginning of the Little Ice Age in Eastern Mediterranean. An approach of physical and anthropogenic evidence', in Belke, K., Hild, F., Koder, J., and Soustal, P. (eds.), Byzanz als Raum. Zu Methoden und Inhalten der historischen Geographie des Östlichen Mittelmeerraumes, Veröffentlichung der Kommission für die Tabula Imperii Byzantini, Denkschrift 7, pp. 223-243.

Telelis, I.: 2004, Meteorological Phenomena and Climate in Byzantium: Approach of sources' information and empirical indications concerning climatic fluctuations in Eastern Mediterranean and the Middle East (A.D. 300-1500), Academy of Athens, Ponimata No. 5, Athens, 924 pp. (in Greek with English summary).

Tetzlaff, G., Börngen, M., and Raabe, A.: 2001, 'Das Jahrtausendhochwasser von 1342 und seine meteorologische Ursachen', in Nürnberger Wasserwirtschaftstage, ATV-DVWK Landesverband Bayern, pp. 5-22.

Tol, R. S. J. and Langen, A.: 2000, 'A concise history of Dutch river floods', Clim. Change 46, 357-369.

Tyrrell, J. G.: 1995, 'Paraclimatic statistics and the study of climate change: The case of the Cork region in the 1750s', Clim. Change 29, 231-245.

Ungar, S.: 1999, 'Is strange weather in the air? A study of U.S. national network news coverage of extreme weather events', Clim. Change 41, 133-159.

van Caenegem, R. C.: 1979, Guide to the Sources of Medieval History, North Holland Publishing Company, Amsterdam, 428 pp.

van den Dool, H. M., Krijnen, H. J., and Schuurmans, C. J. E.: 1978, 'Average winter temperatures at De Bilt (the Netherlands): 1634-1977', Clim. Change 1, 319-330.

van Engelen, A. F. V., Buisman, J., and IJnsen, F.: 2000, 'Reconstruction of the Low countries temperature series AD 764-1998', in Mikami, T. (ed.), Proceedings of the International Conference on Climate Change and Variability - Past, Present and Future, Tokyo Metropolitan University, Tokyo, pp. 151-157.

van Engelen, A. F. V., Buisman, J., and IJnsen, F.: 2001, 'A millennium of weather, winds and water in the Low Countries', in Jones, P. D., Ogilvie, A. E. J., Davies, T. D., and Briffa, K. R. (eds.), History and Climate: Memories of the Future?, Kluwer Academic/Plenum Publishers, New York, Boston, Dordrecht, London, Moscow, pp. 101-124.

van Engelen, A. F. V. and Geurts, H. A. M.: 1985, Nicolaus Cruquius (1675-1754) and his meteorological observations, Koninklijk Nederlands Meteorologisch Instituut 165-IV, De Bilt, 155 pp.

Vinnikov, K. Ya., Groisman, P. Ya., and Lugina, K. M.: 1990, 'Empirical data on contemporary global climate changes (temperature and precipitation)', J. Climate 3, 662-677.

von Brandt, A.: 1996, Werkzeug des Historikers, 14th edn., Kohlhammer, Stuttgart, 246 pp.

von Storch, H.: 2004, 'A discourse about quasi-realistic climate models and their applications in paleoclimatic studies', in Fischer, H., Kumke, T., Lohmann, G., Flöser, G., Miller, H., von Storch, H., and Negendank, J. F. W. (eds.), The Climate in Historical Times. Towards a synthesis of Holocene proxy data and climate models, Springer Verlag, Berlin, Heidelberg, New York, pp. 4356.

von Storch, H., Cubasch, U., González-Rouco, F. J., Jones, J. M., Widmann, M., and Zorita, E.: 2000, 'Combining paleoclimatic evidence and GCMs by means of Data Assimilation Through 
Upscaling and Nudging (DATUN)', in 11th Symposium on Global Change Studies, American Meteorological Society, pp. 28-31.

von Storch, H. and Hasselmann, K.: 1996, 'Climate variability and change', in Hempel, G. (ed.), The Ocean and the Poles. Grand Challenges for European Cooperation, Gustav Fischer Verlag, Jena, Stuttgart, New York, pp. 33-58.

von Storch, H. and Stehr, N.: 1997, 'The case for the social sciences in climate research', Ambio 26, 66-71.

von Storch, H. and Stehr, N.: 2000, 'Climate change in perspective. Our concerns about global warming have an age-old resonance', Nature 405, 615.

von Storch, H. and Stehr, N.: 2002, 'Towards a history of ideas of anthropogenic climate change', in Wefer, G., Berger, W. H., Behre, K.-E., and Jansen, E. (eds.), Climate Development and History in the North Atlantic Realm, Springer-Verlag, Berlin, Heidelberg, New York, Barcelona, Hong Kong, London, Milan, Paris, Tokyo, pp. 17-23.

Vogel, R. B., Egger, H., and Schweingruber, F. H.: 1996, 'Interpretation extremer Jahrringwerte in der Schweiz anhand von klima-historischen Aufzeichnungen zwischen 1525 und 1800 A.D.', Vierteljahrsschrift der Natf. Ges. Zürich 141, 65-76.

Vose, R. S., Schmoyer, R. L., Steuer, P. M., Peterson, T. C., Heim, R., Karl, T. R., and Eischeid, J.: 1992, The global historical climatology network: long-term monthly temperature, precipitation, sea level pressure, and station pressure data, Report ORNL/CDIAC-53, NDP-041.

Wales-Smith, G. B.: 1971, 'Monthly and annual totals of rainfall representative of Kew, Surrey, for 1697 to 1970 ', Meteorol. Mag. 100, 345-362.

Wang, R., Wang, S., and Fraedrich, K.: 1991, 'An approach to reconstruction of temperature on a seasonal basis using historical documents from China', Int. J. Climatol. 11, 381-392.

Wanner, H., Beck, C., Brázdil, R., Casty, C., Deutsch, M., Glaser, R., Jacobeit, J., Luterbacher, J., Pfister, C., Pohl, S., Sturm, K., Werner, P. C., and Xoplaki, E.: 2004, 'Dynamic and socioeconomic aspects of historical floods in Central Europe', Erdkunde 58, 1-16.

Wanner, H., Brázdil, R., Frich, P., Frydendahl, K., Jonsson, T., Kington, J., Pfister, C., Rosenørn, S., and Wishman, E.: 1994, 'Synoptic interpretation of monthly weather maps for the late Maunder Minimum (1675-1704)', in Frenzel, B., Pfister, C., and Gläser, B. (eds.), Climatic Trends and Anomalies in Europe 1675-1715, Gustav Fischer Verlag, Stuttgart, Jena, New York, pp. 401424.

Wanner, H., Brönnimann, S., Casty, C., Gyalistras, D., Luterbacher, J., Schmutz, C., Stephenson, D. B., and Xoplaki, E.: 2001, 'North Atlantic Oscillation - concepts and studies', Surveys in Geophysics 22, 321-382.

Wanner, H., Holzhauser, H., Pfister, C., and Zumbühl, H.: 2000, 'Interannual to century scale climate variability in the European Alps', Erdkunde 54, 62-69.

Wanner, H. and Luterbacher, J.: 2002, 'The LOTRED approach - a first step towards a "paleoreanalysis” for Europe', PAGES News 10, 9-11.

Wanner, H., Pfister, C., Brázdil, R., Frich, P., Frydendahl, K., Jónsson, T., Kington, J., Lamb, H. H., Rosenørn, S., and Wishman, E.: 1995, 'Wintertime European circulation patterns during the late Maunder Minimum cooling period (1675-1704)', Theor. Appl. Climatol. 51, 167-175.

Weichselgartner, J.: 2000, 'Hochwasser als soziales Ereignis. Gesellschaftliche Faktoren einer Naturgefahr', Hydrologie und Wasserbewirtschaftung 44, 122-131.

Weikinn, C.: 1958-2002, Quellentexte zur Witterungsgeschichte Europas von der Zeitwende bis zum Jahre 1850. Hydrographie, Akademie-Verlag, Teil 1 (Zeitwende-1500), 1958; Teil 2 (1501-1600), 1960; Teil 3 (1601-1700), 1961; Teil 4 (1701-1750), 1963; Teil 5 (1751-1800), 2000; Teil 6 (1801-1850), 2002.

Werner, P. C. and Gerstengarbe, F.-W.: 2003, 'Visual meteorological observations as indicators of climate changes, derived from long-term time series of the Potsdam station', Meteorol. Zeitschrift 12, 47-50. 
Wheeler, D.: 1995, 'The weather vocabulary of an eighteenth-century mariner: The log-books of Nicholas Pocock, 1740-1821', Weather 50, 298-304.

Wheeler, D.: 2001, 'The weather of the European Atlantic seabord during October 1805: An excercise in historical climatology', Clim. Change 48, 361-385.

Wheeler, D.: 2003, 'The weather during the voyage of the Royal Spanish Mail Ship Grimaldi, February-March 1795', Weather 58, 20-28.

Widmann, M., Jones, J., and von Storch, H.: in press, 'Reconstruction of large-scale atmospheric circulation and data assimilation in palaeoclimatology', PAGES Newsletter.

Wigley, T. M. L.: 1978, 'Climatic change since 1000 AD', in Évolution des atmosphères planétaries et climatologie de la terre, Centre national d'etudes spatiales, Toulouse, pp. 313-323.

Wigley, T. M. L., Huckstep, N. J., Ogilvie, A. E. J., Farmer, G., Mortimer, R., and Ingram, M. J.: 1985, 'Historical climate impact assessments', in Kates, R. W., Ausubel, J. H., and Berberian, M. (eds.), Climate Impact Assessment. Studies of the Interaction of Climate and Society, Wiley, Chichester, New York, Brisbane, Toronto, Singapore, pp. 529-563.

Wigley, T. M. L., Ingram, M. J., and Farmer, G. (eds.): 1981, Climate and History. Studies in Past Climates and Their Impact on Man, Cambridge University Press, Cambridge, 530 pp.

Williams, A. and Archer, D.: 2000, 'The use of historic flood information in the English Midlands to improve risk assessment', Hydrol. Sci. J. 47, 67-76.

Wishman, E., Frenzel, B., and Weiss, M. M. (eds.): 1998, Documentary Climatic Evidence for 17501850 and the fourteenth century, Gustav Fischer Verlag, Stuttgart, Jena, Lübeck, Ulm, 192 pp.

Xoplaki, E., Maheras, P., and Luterbacher, J.: 2001, 'Variability of climate in meridional Balkans during the periods 1675-1715 and 1780-1830 and its impact on human life', Clim. Change 48, 581-615.

Yan, Z., Alexandre, P., and Demarée, G.: 1997, 'Narrative warm/cold variations in continental western Europe, AD 708-1426', Science in China 40, 509-517.

Zinke, J., von Storch, H., Müller, B., Zorita, E., Rein, B., Mieding, H. B., Miller, H., Lücke, A., Schleser, G. H., Schwab, M. J., Negendank, J. F. W., Kienel, U., González-Rouco, J. F., Dullo, C., and Eisenhauser, A.: 2004, 'Evidence for the climate during the Late Maunder Minimum from proxy data available within KIHZ', in Fischer, H., Kumke, T., Lohmann, G., Flöser, G., Miller, H., von Storch, H., and Negendank, J. F. W. (eds.), The Climate in Historical Times. Towards a synthesis of Holocene proxy data and climate models, Springer Verlag, Berlin, Heidelberg, New York, pp. 397-414.

Zorita, E. and González-Rouco, J. F.: 2002, 'Are temperature-sensitive proxies adequate for North Atlantic Oscillation reconstructions?', Geophys. Res. Lett. 29, 14-17.

Zorita, E., von Storch, H., González-Rouco, F., Cubasch, U., Luterbacher, J., Legutke, S., FischerBruns, I., and Schlese, U.: in press, 'Transient simulation of the climate of the last five centuries with an atmosphere-ocean coupled model: The Late Maunder Minimum and the Little Ice Age', Meteorol. Zeitschrift. 